\section{unesp}

UNIVERSIDADE ESTADUAL PAULISTA "JÚLIO DE MESQUITA FILHO"

Campus de São José do Rio Preto

SANDRA APARECIDA FERNANDES LOPES FERRARI

LÍRICA E INTERLOCUÇÃO EM HILDA HILST

São José do Rio Preto - SP

2016 


\section{LÍRICA E INTERLOCUÇÃO EM HILDA HILST}

Tese apresentada ao Instituto de Biociências, Letras e Ciências Exatas da Universidade Estadual Paulista "Júlio de Mesquita Filho", Câmpus de São José do Rio Preto, para obtenção do título de Doutora em Letras, Área de Concentração em Teoria da Literatura.

Orientadora: Profa. Dra. Norma Wimmer

São José do Rio Preto - SP 
Ferrari, Sandra Aparecida Fernandes Lopes.

Lírica e interlocução em Hilda Hilst / Sandra Aparecida Fernandes Lopes Ferrari. -- São José do Rio Preto, 2016

$151 \mathrm{f}$.

Orientador: Norma Wimmer

Tese (doutorado) - Universidade Estadual Paulista "Júlio de Mesquita Filho", Instituto de Biociências, Letras e Ciências Exatas

1. Literatura brasileira - Séc. XX - História, Crítica - Teoria, etc. 2.Poesia lírica. 3. Hilst, Hilda, 1930-2004 - Crítica e interpretação.

4. Análise do discurso literário. I. Wimmer, Norma. II. Universidade Estadual Paulista "Júlio de Mesquita Filho". Instituto de Biociências, Letras e Ciências Exatas. III. Título.

$$
\text { CDU -B869.015"19" }
$$

Ficha catalográfica elaborada pela Biblioteca do IBILCE UNESP - Câmpus São José do Rio Preto 


\title{
LÍRICA E INTERLOCUÇÃO EM HILDA HILST
}

\author{
COMISSÃO EXAMINADORA
}

Profa. Dra. Norma Wimmer (orientadora) UNESP/São José do Rio Preto

Profa. Dra. Giséle Manganelli Fernandes UNESP/São José do Rio Preto

Prof. Dr. Nelson Luís Ramos

UNESP/São José do Rio Preto

Prof. Dr. Osvaldo Copertino Duarte UNIR - Campus Vilhena

Profa. Dra. Mail Marques de Azevedo.

UNIANDRADE

São José do Rio Preto

Agosto / 2016 
Esta pesquisa contou com o apoio da Capes, com bolsa de estágio doutoral, por um período de nove meses. 
A Maria Inez e Nelson por me darem a vida. Paulo Cesar, por dividir sua vida comigo. Saulo e Sávio, por existirem e serem parte de mim. 


\section{AGRADECIMENTOS}

A Deus, força e sustento.

À Professora Dra. Norma Wimmer, que aceitou orientar os caminhos desta tese em seu percurso final e o fez com excelência.

Ao Prof. Dr. Arnaldo Franco Junior e ao Prof. Dr. Marcio Schell, pela leitura atenta e sugestões no Exame de Qualificação.

Aos funcionários da Seção de Pós-graduação do IBILCE/UNESP, pela atenção e presteza e aos Coordenadores do DINTER/UNIR/UNESP, Professor Dr. Osvaldo Copertino Duarte e Professora Dra. Giséle Manganelli Fernandes.

À CAPES, pela concessão de bolsa de estágio doutoral.

Ao Reitor do IFRO - Instituto Federal de Educação, Ciência e Tecnologia de Rondônia, Professor Raimundo Vicente Jimenez e à Diretora do Campus Vilhena, Professora Maria Fabíola Moraes Assumpção Santos, pela concessão de afastamento de dezoito meses das atividades para a realização desta pesquisa.

Ao Professor Dr.Valdir Barzotto, da FEUSP, pelas lições sobre escrita, pelas conversas e troca de experiências, pelo respeito e atenção.

À minha família, principalmente ao meu esposo, Paulo Cesar, que soube entender minhas ausências.

À Milena, amiga e orientadora "não institucional”, sempre disposta a ler meus escritos.

À Lilian, pelo cuidado e atenção, mesmo estando distante.

Ao Dirceu, pelas lições de francês.

À Gicelma, companheira de trabalho, pela English Lesson.

Por fim, à Rosana e ao Eduardo (Rô e Dudu), pela amizade, por dividirmos as alegrias e as não alegrias, pelo companheirismo nos nove meses de gestação dos primeiros ares de vida desta tese. Eles me proporcionaram grandes lições de amizade, daquelas que perduram para sempre. 
Se eu falasse a voz do mundo como falaria? Se eu falasse com a voz dos ancestrais, sangue, o sêmen do mundo em mim, a refulgência de uma nova voz? Voz vivosa na laringe de Tadeu, pomo de Adão enriquecido de contorções e nódulos: nós, os daqui, os do outro lado, dimensão que não vês, te olhamos, Tadeu, duro arrebato: que sim. Te foi dado caminhar a razão, então caminha. Que sim. (Hilda Hilst em: Tu não te moves de ti) 


\section{Resumo}

Com este trabalho de pesquisa, pretendemos averiguar a constituição interlocutiva da lírica e suas implicações para os estudos literários, tomando como ponto de análise as obras Cantares do sem nome e de partidas, Do Desejo e Ode descontínua e remota para flauta e oboé: De Ariana para Dionísio, de Hilda Hilst. O objetivo principal consiste em refletir sobre as relações tensivas entre o "eu" e o "outro" que tais obras apresentam, e de que modo esses procedimentos artísticos atribuem sentidos à subjetividade lírica de seus versos por meio de um processo de interlocução. Partimos das relações estabelecidas por teóricos que pensaram sobre a definição do gênero lírico e suas formas de representação, começando por Hegel, em Curso de estética, vol. IV; Emil Staiger, em Conceitos fundamentais da poética e Yves Stalloni, em Os gêneros literários, contrastando a ideia de exteriorização do eu de Hegel com a ideia do "sujeito lírico fora de si" de Michel Collot, na constituição da voz lírica hilstiana. Para estabelecer conexões do texto poético com seu interlocutor, traremos também para reflexão a dialética entre as vozes, no ensaio As três vozes da poesia. (1972), de T.S. Eliot, em que será possível traçar o percurso de lírica e interlocução. A partir dessas relações, buscaremos compreender o lugar que ocupa a poesia de Hilda Hilst no panorama artístico brasileiro.

Palavras-chave: Hilda Hilst; interlocução; lírica. 


\begin{abstract}
In this research paper we intend to investigate the interlocution of the lyric and its implications for the literary studies, taking as analysis point the literary works Cantares do sem nome e de partidas, Do Desejo e Ode descontínua e remota para flauta e oboé: De Ariana para Dionísio de Hilda Hilst. The main objective is to think about the relationships between "the speaker" and the "other" that such works present, and how these artistic procedures give meaning to the lyric subjectivity of their verses, through a process of interlocution. The starting point is the relations established by the theorists who thought about the definition of lyrical gender and its representations, starting with Hegel, in Curso de Estética, Vol. IV, Emil Staiger, in Conceitos Fundamentais da Poética and Ives Satalloni, in Os Gêneros Literários, in constrast to the idea of externalization of the "speaker" of Hegel with the idea from the lyrical subject "out of his mind" from Michel Collot, in the constitution of the hilstiana lyrics voice. For this, we will also bring to reflection the dialectics between the voices, in the essay As Três Vozes da Poesia (1972), by T.S. Eliot, where it is possible to set a route of lyrics and interlocution. From this relations we will seek to understand the place that the poetry of Hilda Hilst occupies in Brazilian art scene.
\end{abstract}

Key words: Hilda Hilst; interlocution; lyrics. 


\section{SUMÁRIO}

INTRODUÇÃ

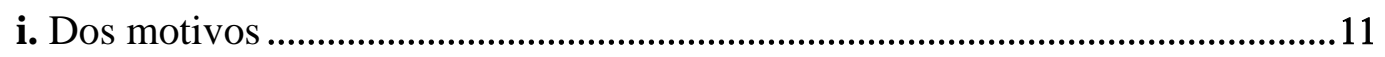

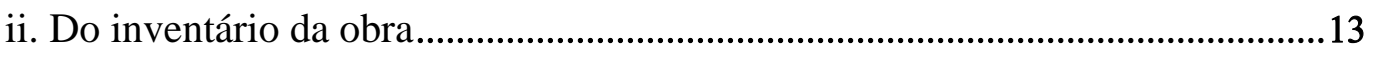

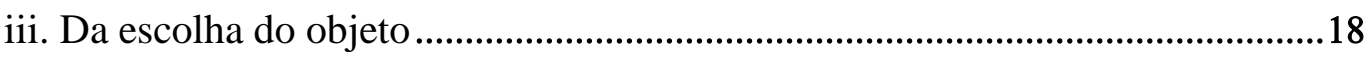

iv. Da organização dos capítulos ..........................................................................24

1. CAPÍTULO I - DA LÍRICA E DOS CANTARES .........................................29

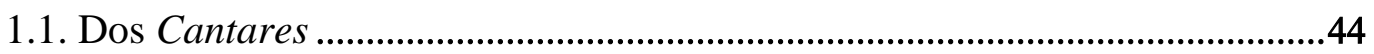

1.2. Dos Cantares do sem nome e de partidas.......................................................46

2. CAPÍTULO II - DA LÍRICA DO DESEJO ......................................................73

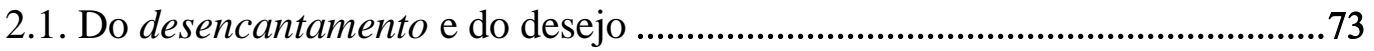

2.2. Da reunião Do Desejo ..........................................................................................79

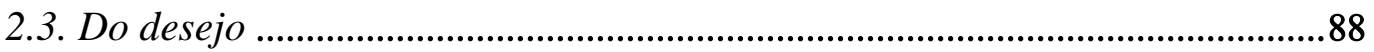

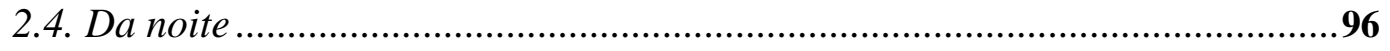

3. CAPÍTULO III - DA INTERLOCUÇÃO LÍRICA COMO AUSÊNCIA........ 106

3.1. "Minha extensa e difícil dialética lírica" .......................................................129

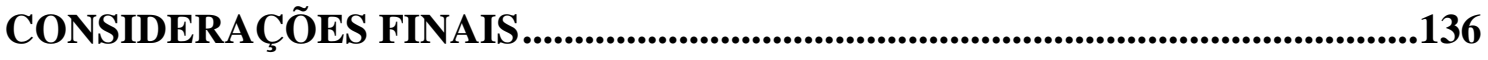

REFERÊNCIAS BIBLIOGRÁFICAS........................................................................142 


\section{INTRODUÇÃO}

\section{i. Dos motivos}

A poesia lírica, que se faz aqui objeto de estudo, instaura-se em um universo de tensões feitas por meio de vários termos opostos que se cruzam, mas não se excluem, dialogam entre si num movimento relacional, formando novas configurações para o poético. Partindo desse pressuposto, escolhemos para análise parte da obra poética de Hilda Hilst porque, em sua vasta produção escrita em prosa de ficção, poesia, teatro e crônica, encontra-se um discurso que abarca questões sobre o modo como a autora tensiona a linguagem, na performance de um estilo próprio. Ademais, veremos que as tensões, na obra de Hilst, manifestam-se no modo como trata os termos opostos configurados em seu discurso, tais como espírito e matéria, sagrado e profano, corpóreo e incorpóreo, linguagem e interlocução.

O intuito em investigar parte da produção poética de Hilst é refletir acerca de algumas questões suscitadas nos estudos sobre a lírica, tendo como uma das hipóteses a problematização dos gêneros da qual se abstrai a poética hilstiana. Independente das noções tradicionais de gênero, vistas como imutáveis, entre lírico, narrativo e dramático, veremos, em Hilst, que essa terminologia de gêneros não se aplica. Mesmo tendo escrito a maior parte de sua obra em forma de poema, ao escrever prosa ou teatro, há uma aderência à poesia. Em Fluxo-floema (1970), obra inaugural de sua prosa, encontra-se uma fundamental singularidade da poética hilstiana, como se lhe fosse impossível exprimir-se por meio de um único aspecto formal, aderindo, portanto a uma junção dos gêneros. Em prefácio à primeira edição de Fluxo-floema, Anatol Rosenfeld aponta a junção de gêneros como "enunciação da totalidade do homem através da sua 
multiplicidade - e essa visão prismática ou caleidoscópica forçosamente teria que recorrer a todos os gêneros para exprimir-se na sua plenitude" (1970, p. 15). Desta forma, é possível ver a escrita de Hilst, quer na prosa, drama ou poesia, num lugar do "entre", que não elimina as dicotomias, porque elas dialogam entre si.

Essa posição de escrita faz da poesia a forma preferida da autora. Ela repetiu, em várias entrevistas, (como é o caso da entrevista cedida à Clelia Pisa e Maryvonne Lapouge, 1977, publicada em “Brasileiras: voux, écrits du Brésil”, e recolhida por DINIZ, 2003, p. 37) que, mesmo quando escrevia prosa de ficção ou dramaturgia, estava escrevendo poesia. Afirmava que a prosa é muito mais previsível. Gostava de ser chamada de poeta, porque, segundo ela, a palavra "poetisa" referia-se a moças donzelas que escreviam versos para ocupar o tempo. Em outra entrevista dada à Sonia de Amorim Mascaro, em 1986, Hilda relaciona o amor ao ato de escrever: "Escrever ficção é um trabalho mais ou menos disciplinado. A poesia não. A poesia você não programa, é um estado quase inexplicável porque surge a qualquer momento. O primeiro verso aparece pra você” (DINIZ, 2013, p.91).

A poesia, gênero preferido da poeta, não se sobrepõe a uma evolução formal, mais do que isso, representa a relação do "sujeito" com o seu ato poético e a constituição de seu lugar, cuja voz problematiza as formas de lírica. A questão sobre a voz do eu lírico na poesia de Hilst é trazida para esta pesquisa no sentido de pensar acerca de um tipo de subjetividade, advindo do desejo de si no outro. O eu lírico se exterioriza para se realizar no outro, em um investimento consciente de estar sob a égide do desejo de ser sujeito e objeto dele na plenitude da falta. Neste caso, ser desejante ou ser objeto da ardência alheia manifesta-se na ficcionalização de um interlocutor ausente. Fato que torna possível o sujeito encontrar-se em si, pelo outro, e se tornar sujeito e objeto ao mesmo tempo. 
Para refletir sobre o processo de subjetividade na criação poética hilstiana, partimos do pressuposto de que, herdeiro da modernidade, o poeta passa a depender da “cumplicidade do leitor na decifração de uma linguagem que, dissipada pela consciência, já inclui tanto poeta como leitor" (BARBOSA, 2009, p. 22). E essa cumplicidade, em Hilst, é percebida pelo modo como se instala a ação interlocutiva manifestada nas obras escolhidas para esta pesquisa. A interlocução se dá de várias maneiras: com as formas da tradição e modernidade na relativização dos gêneros; com o amado, pela presença constante de uma segunda pessoa, sempre representada por um "tu"; com o próprio poema.

\section{ii. Do inventário da obra}

Para os motivos mencionados acima se tornarem melhor delineados, é importante, inicialmente, fazermos um breve inventário da produção de Hilda Hilst. A escritora possui uma obra extensa: mais de quarenta livros, (de poesia, de 1950 a 1995; de prosa de ficção, de 1970 a 1997; de dramaturgia, de 1967 a 1969; e de crônicas, de 1992 a 1995), cujo traço marcante é a busca de um interlocutor identificável por meio de um discurso oscilante entre a experiência da poeta e a experiência de linguagem. Hilst nasceu em Jaú, no interior de São Paulo, no dia 21 de abril de 1930, mas morou grande parte de sua vida em uma chácara localizada entre Campinas e Valinhos, batizada por ela de "Casa do Sol", hoje sede do Instituto Hilda Hilst. O exílio voluntário da autora na "Casa do sol”, após a década de 1960, contribuiu para a criação de grande parte de sua obra. Sua carreira de poeta tem início com a publicação do livro Presságio, lançado pela Revista dos Tribunais, de São Paulo, em 1950. Esse livro, mais tarde, integra o volume Baladas, 2003, publicado pela Editora Globo, que reúne também Balada de Alzira (1951) pelas Edições Alarico, São Paulo, e Balada do festival (1955), Jornal de Letras, Rio de Janeiro. 
Ingenuidade julgar este livro como uma composição de juventude de tom apenas confessional. A poética nele encontrada reverbera um "eu" distinto da simples poesia de juventude, representada por uma dicção romântica e descompromissada. São paradoxos apresentados de forma mais amena; todavia delineiam-se neles os níveis da linguagem e dos motivos adotados pela poeta no conjunto de sua obra. É um livro de grande tensividade discursiva, porque apresenta um "eu" incompleto e amargurado incapaz de se conter no mundo em que vive, e aborda temas e motivos fundamentais para sua criação posterior. O poema abaixo aponta para este discurso embrião:

\title{
VI
}

\author{
Água esparramada em cristal, \\ buraco de concha, \\ segredarei em teus ouvidos \\ os meus tormentos. \\ Apareceu qualquer cousa \\ em minha vida toda cinza, \\ embaçada, como água \\ esparramada em cristal. \\ Ritmo colorido \\ Dos meus dias de espera, \\ duas, três, quatro horas, \\ e os teus ouvidos \\ eram buracos de concha, \\ retorcidos \\ no desespero de não querer ouvir. \\ Me fizeram de pedra \\ quando eu queria \\ ser feita de amor.
}

(HILST, Hilda. Baladas. 2003, p. 28)

Dizendo em poucas palavras, temos no poema uma voz formada pela imagem da água, no primeiro verso: “esparramada em cristal”. Há um conflito no processo interlocutivo de uma voz que quer ser ouvida por um interlocutor, e este se nega a ouvir: "segredarei aos teus ouvidos / os meus tormentos", [...] e os teus ouvidos / eram buracos de concha, / retorcidos /no desespero de não querer ouvir. [...]". Um tom de pessimismo apresenta um estado de insatisfação com a condição de ser: "Me fizeram de pedra / 
quando eu queria/ ser feita de amor" As imagens "água esparramada", "ritmo colorido" sugerem, quase ironicamente, uma poesia cuja forma desmente o tom confessional e derramado de sentimentalismo romântico, porque mesmo querendo ser "feita de amor", da fragilidade juvenil, o eu poético hilstiano já se fazia de "pedra" e se impunha como força identitária de seu estilo.

A breve atenção dada aqui a estes primeiros versos de Hilst serve para legitimar um dos aspectos sobre os quais pretendemos refletir, do ponto de vista de sua voz poética, que sai de si, simula interlocução com um outro e volta para si, conforme será delineado nos capítulos desta tese. As questões esboçadas no princípio de sua produção estarão, de forma mais intensa, em toda a sua escrita posterior. O tom reflexivo e dissonante, dialogando com um interlocutor à procura de respostas para questões inerentes ao ser e ao estar no mundo, é parte importante da poesia hilstiana, de forma que este tom sugere, em certos momentos, uma postura de negatividade em relação ao mundo, ao trabalho da poeta e à perpetuação da sua poesia.

Após a publicação dos três primeiros livros de poesia, (Presságio (1950), Balada de Alzira, (1951) e Balada do Festival (1955), Hilst publica: Roteiro do Silêncio (1959), Trova de muito amor para um amado senhor (1960), Ode fragmentária (1961), Sete cantos do poeta para o anjo (1962), Trajetória poética do ser (1963 a 1966). Em 1967, Hilst dá início à publicação de peças teatrais, a saber: A empresa ou A possessa (1967), O rato no muro (1967), O visitante (1968), Auto da barca do Camiri (1968), As aves da noite (1968), O novo sistema (1968), O verdugo ${ }^{1}$ (1969), A morte do patriarca (1969). As quatro primeiras peças são editadas, mais tarde, no livro Teatro reunido, Volume I, em 2000. Em 2008, todas as peças são editadas no volume Teatro completo, pela Editora

\footnotetext{
${ }^{1}$ Esta peça foi publicada pela primeira vez em 1970. Recebeu o prêmio Anchieta.
} 
Globo $^{2}$. Um teatro pouco visto em cena, todavia demarca um lugar de destaque. Segundo Alcir Pécora, em Nota do Organizador, da edição Teatro Completo, a dramaturgia de Hilst foi um “ensaio de sua prosa, que começava a praticar ao lado da poesia”. (2008, p. 7). O exercício dessa escrita contribuiu não só para a nascente prosa, mas, principalmente, para a poesia que dialoga com as formas da sua dramaturgia pela dramaticidade que apresenta em alguns de seus versos.

No mesmo ano em que se inicia na dramaturgia, publica Poesia $(1959 / 1967)^{3}$, seu último livro de poesia antes de tentar a prosa, no qual reúne nove livros publicados nesse período de oito anos ${ }^{4}$. Em 1969, ano de conclusão de sua dramaturgia, escreve Ode descontínua e remota para flauta e oboé. De Ariana para Dionísio, publicado, posteriormente, como parte do livro de Júbilo, memória e noviciado da paixão, em 1974. Neste mesmo ano inicia a escrita de ficção com o texto "O unicórnio", incluso no primeiro livro de contos, o Fluxo-floema, publicado em 1970. Em 1973, lança seu segundo livro em prosa, Qadós, (alterado pela autora para Kadosh em 2002). Em 1974, retoma a escrita de poesia com Júbilo, memória e noviciado da paixão.

Depois de um período de seis anos, lança, em 1980, Da morte, odes mínimas, e, no mesmo ano, Poesia (1959 a 1979). Em 1982 publica $A$ obscena senhora D, uma de suas narrativas mais densas, na qual consegue fazer a junção de aspectos poéticos e dramáticos. Um ano depois, lança o livro Cantares de perda e predileção, poesia,

\footnotetext{
${ }^{2}$ Toda a obra de Hilst foi reeditada postumamente por Alcir Pécora, organizador da coleção "Obras reunidas de Hilda Hilst", pela Editora Globo.

${ }^{3}$ Este livro foi reeditado pela Editora Globo, com o título Exercícios - título dado por Alcir Pécora. A reunião contém os mesmos livros de Poesia 1959/1967, mas com ordem cronológica invertida à da primeira publicação.

${ }^{4}$ Além dos livros citados no parágrafo anterior, esta reunião contém os livros Exercícios para uma ideia (1967), Pequenos funerais cantantes ao poeta Carlos Maria de Araújo (1967), Odes maiores ao pai e Iniciação do poeta.
} 
premiado pela Câmara Brasileira do Livro. Lança Poemas malditos, gozosos e devotos, em1984. Sobre tua grande face e Com os meus olhos de cão e outras novelas são publicados em 1986. Em 1989 lança Amavisse, parte integrante da reunião Do desejo (1992).

Em 1990 mais um livro de poesia, Alcoólicas, e dois dos primeiros títulos de sua "tetralogia obscena": O caderno rosa de Lori Lamby e Contos d'scárnio e Textos grotescos. O terceiro título, Cartas de um sedutor, é lançado em 1991. O último título da tetralogia, Bufólicas, poesia, é publicado em 1992. Neste ano também é lançado Do desejo, livro de poesia que reúne sete livros, dos quais somente os dois primeiros, Do desejo e Da noite, são inéditos. Em 1993, Rútilo nada, (ficção) leva a autora a receber o prêmio Jabuti pela segunda vez. Cantares do sem nome e de partidas, (1995) é o último livro de poesias inéditas. Este comporá o volume Cantares, 2003, editado pela Editora Globo, no qual reúne - também - Cantares de perda e predileção. O último livro inédito de ficção, Estar sendo. Ter sido, foi publicado em 1997. A seguir, a poeta anuncia seu afastamento do trabalho de criação. Segundo ela, tudo o que tinha para dizer já estava dito em suas obras. Em 1998 organiza as crônicas publicadas em jornais de Campinas, no volume Cascos e carícias. E, finalmente, em 1999 reúne poemas no volume Do amor (poemas escolhidos).

Essa descrição cronológica de publicações da obra de Hilda Hilst demonstra o trânsito entre as formas da escrita artística. E de sua vasta obra notamos alguns pontos dignos de reflexão: a lírica como linguagem e seus elementos subjetivos que interagem com o interlocutor, sobretudo, para levá-lo a encontrar o entendimento e a emoção como forma das inquietações do homem de seu tempo e de seu espaço. E essa forma de “comunicação" se configura nas mais variadas maneiras, tanto na questão extrínseca, 
temática, como na relação interna, de diálogo com as formas da tradição poemática, como é o caso do soneto, da elegia, das odes, dos cantares.

\section{iii. Da escolha do objeto}

A partir das questões assinaladas, estabelecemos como corpus nesta pesquisa uma reflexão sobre os livros de poesia Cantares do sem nome e de partidas, da reunião Cantares $^{5}$, (2004); Do desejo e Da noite, do volume Do desejo, (2004) e Ode descontínua e remota para flauta e oboé: De Ariana para Dionísio, do livro Júbilo, memória e noviciado da paixão, (2003). ${ }^{6}$

O volume Cantares $^{7}$, (1995), é uma reunião de dois livros publicados com uma distância de doze anos entre um e outro, 1983 e 1995. O primeiro deles, Cantares do sem nome e de partidas, (1995), foi o último livro de poesia da autora. Pode ser considerado um único poema, dividido em dez partes, pela interligação não só do ponto de vista temático, mas, sobretudo, pela constituição e enredamento de seus versos. Foi denominado pela autora como "roteiro de um amor sonhado", cuja voz se constrói sob o signo de uma mulher que se despede. Isso pode ser visto em verso da parte I: "Que este amor só me veja de partida" (2004, p.17). O segundo livro da reunião, Cantares de perda e predileção, (1983), é composto por setenta poemas ${ }^{9}$. Sua dicção poética maior é a

\footnotetext{
${ }^{5} \mathrm{O}$ Volume Cantares é composto também por um segundo livro, o "Cantares de perda e predileção". Esta pesquisa se deterá apenas no primeiro livro. Mas achamos conveniente ver o conjunto, sem, todavia, determo-nos na análise do segundo livro.

${ }^{6}$ Convém lembrar que, neste período descrito de publicação, os livros Da morte: Odes Mínimas e Poemas malditos, devotos e gozosos não farão parte desta proposta de análise, porque não é intuito principal deste trabalho de pesquisa enfocar os aspectos que demarcam indagações sobre a morte e sobre Deus, já que nesses dois livros há uma preocupação desvelada em tratar de tais temas e motivos.

${ }^{7}$ Título dado por Alcir Pécora, organizador da coleção "Obras reunidas de Hilda Hilst".

${ }^{8}$ Segundo o texto de Carlos Graieb, na contracapa da primeira edição de Cantares do sem nome e de partidas, pela Massao Ohno Editor, 1995.

${ }^{9}$ Com este último, a autora recebeu o Prêmio Jabuti, da Câmara Brasileira do Livro, em 1984.
} 
preocupação em juntar o amor à nomeação de Deus e da vida que se esvai pela fugacidade do tempo. Nisto, dois temas antagônicos são manuseados por Hilda: o amor que agrega os seres e a morte que os separa.

Do Desejo, (1992), é uma reunião composta por: "Do Desejo", "Da Noite", "Amavisse", "Via Espessa", "Via Vazia", "Alcoólicas" e "Sob a tua grande face”. Os dois primeiros títulos, neste livro, são inéditos e foram publicados separadamente dos outros. "Via Espessa", "Via Vazia" e "Amavisse" "faziam parte de um volume chamado Amavisse, lançado originariamente em 1989, pela editora do amigo e mais constante editor de Hilst, Massao Ohno"10. “Alcoólicas", em 1990, pela Maison de Vins, e "Sob tua grande face”, em 1986, também pela Massao Ohno. Nesta reunião, mais especificamente nos dois primeiros livros, sobre os quais se deterá esta pesquisa, Hilst transita numa teia de duas pontas: a representação de um sujeito em conflito e a presença de um outro, no qual o sujeito busca modos de se realizar. Essa dupla relação conota o status do discurso lírico que enuncia o modo de vida do presente como momento de reflexão do ser.

O livro Júbilo, memória, noviciado da paixão foi publicado em 1974. É composto por sete partes aqui designadas "seções", a saber: "Dez chamamentos para um amigo", "O poeta inventa viagem, retorno, e sofre de saudade", "Moderato contabile", "Ode descontínua e remota pra flauta e oboé. De Ariana para Dionísio", "Prelúdios-intensos para os desmemoriados do amor”, “Áreas pequenas. Para bandolim” e "Poemas aos homens do nosso tempo". Destes, apenas “Ode descontínua e remota pra flauta e oboé. De Ariana para Dionísio”, sobre o qual faremos nossa análise, foi escrito como projeto separado, tão logo a autora terminou sua dramaturgia, em $1969^{11}$. Neste livro e nas demais

\footnotetext{
${ }^{10}$ Segundo Alcir Pécora, em nota do organizador ao livro Do desejo, 2004, p.7.

${ }^{11}$ De acordo com informações sobre a Cronologia de Hilst, elaborada por Luisa Destri e Cristiano Diniz, no livro Por que ler Hilda Hilst, organizado por Alcir Pécora, pela Editora Globo, (2010, p. 57).
} 
seções que o compõem, há um sujeito lírico cuja voz marca a espera e o lamento pela ausência do amado. Os “interlocutores” se apresentam personificados em Dionísio, Tulio, amigo, senhores. Estas denominações são intrigantes e merecem ser discutidas, porque a figurativização de personagens da mitologia e da tradição sugere também a referência a esta tradição e a suas formas.

Do ponto de vista extrínseco, a escolha dessas obras se deu pelo fato de marcarem um momento de intenso apuro técnico na lírica da autora: Júbilo memória e noviciado da paixão, de 1974, dá início a uma fase marcada pelo retorno à poesia. Hilst inicia sua carreira de poeta em 1950 e até 1967 tem uma fase de produção de poesia. Mesmo com a produção subsequente de prosa e teatro não se afasta da poesia. Por outro lado, o último livro inédito da autora, Cantares do sem nome e de partidas, publicado em 1995. Desta forma, o percurso a ser seguido: de uma ponta, o livro que marca o recomeço da produção do gênero poesia, com Júbilo, memória e noviciado da paixão, da outra, o seu último livro publicado. No meio desse percurso diacrônico, foi escolhida a reunião Do desejo (1992), por contemplar boa parte dos livros publicados neste espaço de tempo. Em Do desejo, o elemento de interlocução é o desejo como angústia e prazer, cujo fim se concentra nas buscas presentes em todo projeto de escrita hilstiana, que passa pela preocupação com o "vir a ser" da sua obra e suas reflexões sobre o amor e o desejo.

Muito além dessa justificativa histórica de publicação, do ponto de vista diacrônico, estão os elementos intrínsecos comuns constituintes dessas obras. Os livros citados conectam-se por meio de procedimentos discursivos, responsáveis por estabelecer um trânsito entre os vários elementos que os compõem, sobretudo a busca inconsciente e incessante de respostas para o amor e o desejo. Para Hilst, o processo de busca faz acontecer a obra, e não as respostas. E esse processo se constitui pela relação entre o eu lírico e outros interlocutores, configurados em amante e amado, poeta e poesia, presente 
e passado. Essa questão é tão importante na sua obra que, nos livros a serem analisados, as respostas estão sempre em ausência.

Assim, a proposta de reflexão desta tese se concentra, fundamentalmente, em ver como se dá, nos três livros selecionados, a constituição lírica por meio da presença constante de um interlocutor, que é peça fundante e fundamental em sua obra. Tendo como linha de força as formas de interlocução estabelecidas pelo eu lírico, nos três livros, torna-se possível ter uma visão ampla, porém pontual de elementos marcantes da lírica de Hilst.

Para tratar sobre lírica, no que se refere à atuação do sujeito e de sua interlocução, o escopo teórico parte, inicialmente, das noções sobre o gênero, expostas por Hegel (em Curso de estética, vol. IV), sobre a definição geral do lírico de sua subjetividade e o modo como a lírica é tratada, do ponto de vista da relação das formas de representação. Deste modo: "a arte da poesia não pode permanecer presa ao representar poético interior, mas deve confiar as suas configurações à expressão linguística” (HEGEL, 2004, p. 21). Segundo o pensamento de Hegel, a poesia assume uma obrigação dupla: a de dispor seu material (interior) à comunicação linguística; e a de tratar esse material linguístico poeticamente para diferenciar a expressão prosaica da poética. Nesse ponto, podemos falar sobre a questão da comunicação poética, cujo esquema assemelha-se ao da expressão linguística: emissor, receptor e mensagem, ou, no discurso artístico, sujeito lírico, interlocutor, texto. Esse esquema discursivo, na poesia, torna possível a percepção de sentidos e de significações para o texto poético, que residem na obscuridade da imagem e do referente proposto pela linguagem. Em Hilda Hilst, fica visível esse procedimento pela personificação constante de seu interlocutor que se reveste de várias maneiras nas obras em questão. 
O texto lírico insere-se no sistema de enunciação da linguagem. O status de "eulírico" como "sujeito de enunciação", assim como discute Käte Hamburger ${ }^{12}$, em seu livro A lógica da criação literária, permite pensar que a noção de gênero lírico dialoga com o pensamento moderno, no qual o texto poético, pela perspectiva dos estudos da linguagem, constrói-se também como teoria de si. Ao constituir-se como teoria e crítica, o lírico reitera o sistema "enunciador de linguagem" (1992, p. 168). Hamburger infere em suas formulações sobre o lírico que este gênero se faz como enunciado de um sujeito-deenunciação e, por isso, confirma a "definição tradicional como gênero literário subjetivo e realiza um passo no sentido da descrição moderna da poesia como formação linguística" (1992, p. 168).

Na visão de Käte Hamburger sobre o texto poético como texto de formação linguística e em seu diálogo com a definição tradicional de gênero, é possível pensar na relação que essa ideia sobre a poesia pode ter com o significado do termo modernidade, levando em consideração a atuação do sujeito lírico como princípio de toda forma poética. Tendo como premissa de discussão essa atuação do lírico, parece pertinente dizer que a relação entre passado e presente sempre se fez de forma problematizante nos estudos sobre literatura. Todo diálogo implica um confronto entre dois pontos que podem ser divergentes ou convergentes, porque um ponto sempre questiona o outro ou retoma o pensamento do outro, que, por sua vez, converge para uma atitude muitas vezes amistosa.

As implicações sobre o que se concebeu denominar tradição e modernidade, largamente estudadas, e entre modernidade e contemporaneidade, são tensões plausíveis de análise na poética de Hilst, pois sua poesia foi produzida na metade final do século

\footnotetext{
12 Käte Hamburger desenvolve neste livro um estudo sobre gêneros a partir da lógica linguística, que "penetrou a concepção moderna da lógica do pensamento" (1992, p. VII) como crítica da linguagem. A autora faz uma distinção entre a ficção (mimética) e a lírica, sob o aspecto das funções lógico-linguísticas que veem o texto como enunciado comunicativo. Para a autora, a lógica da criação literária é comparada à lógica linguística da criação literária, com fundamento na teoria da linguagem.
} 
XX. Trata-se de uma lírica que foge, até certo ponto, dos padrões tradicionais, ao mesmo tempo em que bebe em suas fontes, produzindo uma espécie de discurso que adere e permeabiliza o tempo passado e o presente.

Tratar de constituição da lírica na modernidade leva a pensar sobre as formas de subjetividades que essa lírica assume e como se adapta ao seu tempo e ao seu espaço. Com o advento da modernidade, a visão de sujeito lírico se desvincula do seu estado confortável de soberania absoluta, fato que gera uma reação considerada como um sintoma de uma crise característica da poesia da modernidade. Por outro lado, nos tempos atuais, essa "crise" ganhou o sinônimo de perda de qualidade, de desprestígio, o que gerou, evidentemente, um rearranjo tanto no discurso poético quanto no crítico.

Este pensamento encaminha para a reflexão da seguinte questão: será que a poesia sob a perspectiva de Hilda Hilst dialoga com a sua identidade primeira de "estado de alma”, conforme propõe a subjetividade lírica encontrada em Emil Staiger, por exemplo, e preserva ou transpõe seus limites? Ao dialogar com a tradição, sua produção poética configura uma nova evocação da realidade que busca uma forma diferente de produzir a reflexão existencial e histórica sobre o sujeito e seus enfrentamentos com questões que constituem o ser.

$\mathrm{Na}$ contemporaneidade, a poesia está ligada não mais à representação pura e simples da ideia de sublime, centrada num "eu" que disserta sobre seus sentimentos em profundidade. A lírica de hoje requer, muito mais do que a lírica tradicional ${ }^{13}$, um interlocutor que participe de sua criação. Celia Pedrosa, na apresentação ao livro "Subjetividades em devir", aponta que a experiência moderna de subjetividade é um efeito daquilo que se pensa heteronômico, em que "se desestabilizam as fronteiras do subjetivo e do objetivo, do racional e do afetivo, do interior e do exterior, do individual e

\footnotetext{
${ }^{13}$ Referimo-nos, com o termo tradicional, à lírica primeira, aquela que desde Safo era cantada e inspirava prostração do ouvinte.
} 
do coletivo, do privado e do público, de modo a propor possibilidades novas de compreensão" (2008, p. 8). Essa relação tensiva é uma das heranças deixadas pela poesia lírica da modernidade do final do século XIX e início do século XX: a comunicação poética possui algo de indigesto e faz o leitor "em estado de choque", expressão utilizada por Hugo Friedrich em seu livro Estrutura da lírica moderna (1991), pensar sobre a intimidade comunicativa. Essas questões, tratadas a seguir, são algumas marcas da obra de Hilda Hilst e serão desenvolvidas no decorrer desta pesquisa.

\section{iv. Da organização dos capítulos}

A tese está dividida em três capítulos. Cada um apresenta pontos de análise comuns entre os três livros selecionados da poeta que traduzem a significação da lírica dessas obras. No primeiro capítulo, pretendemos trazer para a discussão um percurso teóricocrítico do conceito de lírica, sendo o livro Cantares do sem nome e de partidas o foco de análise. Desta maneira, será discutida a noção de subjetividade do eu lírico de Hilst, tendo como ponto de entendimento a linguagem na sua obra poética. Para que essa ideia seja delineada no decorrer do primeiro capítulo, é necessário rever questões sobre a lírica e discuti-las na obra hilstiana, sobretudo a partir das ideias de Emil Staiger, Hugo Friedrich, Yves Stalloni, bem como do pensamento acerca de subjetividade e a atuação da voz lírica proposta por G. W. F. Hegel em contraponto com Michel Collot.

Em seu ensaio "O sujeito lírico fora de si” (2004), Michel Collot trabalha com a hipótese de que a saída de si do sujeito ${ }^{14}$ lírico se faz regra na modernidade. É preciso,

\footnotetext{
${ }^{14}$ Convém lembrar que a expressão "sujeito lírico" é um legado da modernidade desde Baudelaire. Ele anuncia a poesia moderna, mas é com Mallarmé que essa será vista como ideia, ou seja, na relação entre sujeito, palavra e mundo, conforme infere T.S. Eliot em A essência da poesia. Em Hilda Hilst, veremos um tipo lírico que oscila, anacronicamente, como um pêndulo, pelas instâncias diferentes do eu e o do sujeito. Dessa relação, entretanto, predomina um "eu" incisivo. Isso será melhor delineado no decorrer desta pesquisa.
} 
entretanto, entender que esse processo de "saída de si" do sujeito lírico configura-se de forma diferente na poesia de Hilst. Se, para o autor do ensaio, o "estar fora de si é ter perdido o controle de seus movimentos interiores e, a partir daí, ser projetado em direção ao exterior" (2004, p. 166), em Hilst, esse movimento de saída busca interlocução com um outro, que ela elege como interlocutor em ausência. Desta forma, o sujeito lírico não se perde fora de si, antes volta para seus próprios sentimentos, não de forma intimista, e gera uma situação de dependência entre ele (o sujeito lírico) e o outro, (o interlocutor). E o outro não só em presença, mas também em ausência, como se dá no poema III de Cantares do sem nome e de partidas, nos últimos versos: "Como pode ser isso? Ser tenro, marulhoso / Dançarino e novo, ter nome de ninguém / E preferir ausência e desconforto / Para guardar no eterno o coração do outro" (HILST, 2004, p.19).

Discutiremos, ainda, neste capítulo, a ideia do "sujeito lírico fora de si”, de Collot, contrastada com a exteriorização do eu de Hegel. Para este, o eu ainda acredita na palavra e na possibilidade de objetivar a ideia por meio da imagem. Em Collot, o sujeito é tomado pela palavra. Desta forma, veremos como a poesia de Hilst se instaura nessa ponte entre um sujeito descentrado e um eu que domina a linguagem e que sabe onde quer chegar.

No segundo capítulo pretendemos fazer uma leitura dos dois primeiros livros da reunião Do desejo e propor uma investigação sobre sentidos da lírica advindos da modernidade. Esses, na obra, mostram o eu movido pelo desejo e a experiência de subjetividade, que desorganiza o ser e o mundo no sentido de colocá-los sempre em estado de instabilidade.

Os desdobramentos do desencantamento de mundo, perceptíveis na modernidade, em que há a perda das aspirações transcendentes, num mundo cada vez mais racionalizado, explicado pela ciência e determinado pela técnica, enfocam o homem visto não mais na coletividade, mas no seu estado de indivíduo. Com isso, sua existência é 
colocada em conflito, instaurando uma crise de identidade. Essa crise é gerada pelo desejo de representar-se. Com o "ser ou não ser" de Hamlet, foi rompida a experiência religiosa da vida e do mundo, as certezas se abalaram e rompeu-se também a integridade do homem: “como posso desejar se desconfio de mim, se nem sei se sou?" Ou: "Como posso desejar se estou o tempo todo a duvidar?” (SANTOS, 1990, p. 212). Essas questões produzem um desajuste no modo de conceber também a obra de arte. Do ponto de vista da criação poética hilstiana, traremos para reflexão a atuação do eu lírico, que se desloca da sua zona de conforto e assume um perfil diferente de subjetividade, gerado pela interlocução com a modernidade. Uma das questões que constituem a lírica desses livros é que o desejo não é apenas objeto, mas apresenta-se também como sujeito, na relação interlocutiva. No caso do livro Do desejo, esses paradoxos se instauram na impossibilidade de se definir o amor, ora como corpo, ora como espírito: “[...] O desejo /Este da carne, a mim não me faz medo" (HILST, 2004, p. 21).

O sentido de lírica como uma voz que fala ao seu amado, reclamando a sua ausência, será trabalhado no terceiro capítulo, no qual pretendemos investigar os procedimentos de como se dão as formas dessa interlocução lírica, na obra Júbilo, memória e noviciado da paixão, sobretudo, em "Ode descontínua e remota para flauta e oboé. De Ariana para Dionísio”. Enfatizaremos alguns pontos passíveis de análise sobre a comunicação poética como função intrínseca no sentido de trazer para a discussão a presença de uma voz que sempre se dirige a um interlocutor ausente/presente. Esse jogo de ausência e presença é ponto fundamental da obra, pois é por ele que sua poesia se apresenta: No primeiro poema do livro tem-se o seguinte verso: “[...] E o verso a cada noite / Se fazendo de tua sábia ausência” (HILST, 2003, p.59).

Os elementos de diálogo e contradiálogo com a tradição das formas, no caso, a ode, apresentam-se, neste livro, como uma voz dissonante, manifestada, no nível da 
linguagem, como um modo de reconfigurar esse status formal. Na constituição do discurso do livro está um eu lírico, cuja voz é a espera e o suposto lamento pela ausência do amado, seu interlocutor. Para tanto, é possível pensar sobre a dialética tensiva entre as vozes, descritas no ensaio As três vozes da poesia. (1972), de T.S. Eliot. Neste ensaio, o autor infere que há três vozes na poesia moderna: a voz do poeta que fala de si mesmo, a que se manifesta diante de um público e a que tenta criar uma personagem dramática que dialoga com outros seres imaginários. Nesse sentido, o lugar de onde fala a voz poética de Hilst e suas relações tensivas com o contexto de criação são questões plausíveis de reflexão crítica.

A produção de sentidos na lírica de Hilst é vista, nesta perspectiva, como discurso produtor de sentidos a partir das vozes que dialogam entre o eu e o tu e tem o enunciado poético como ponte entre essas vozes. A comunicação poética é traço marcante e constitui entre o eu e o tu um jogo de sedução. Esse jogo parte não só dos elementos temáticos que demarcam a poesia da modernidade, no que se refere à atuação ativa do leitor/interlocutor, mas também da forma, colocando eu e tu na via de mão dupla entre interlocutor e texto. Dessa forma, tendo como base as discussões acima propostas sobre as relações constitutivas da forma lírica e com a análise imanente dos livros selecionados para esta tese, será possível delinear uma compreensão da poética hilstiana e seu modo de inscriç̃̃̃ interlocutiva, de forma a inseri-la no panorama das discussões da lírica contemporânea. 
CAPÍTULO I 


\section{DA LÍRICA E DOS CANTARES}

Soergo meu passado e meu futuro E digo à boca do Tempo que os devore.

E degustando o êxito do Agora A cada instante me vejo renascendo.

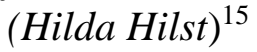

A reunião Cantares (2004) cuja composição é feita por dois livros, Cantares do sem nome e de partidas (1995) e Cantares de perda e predileção (1983) estabelece-se por uma série de motivos e formas poemáticas que se apresentam como um forte trânsito entre presente e passado e levam a refletir sobre um traço marcante na experiência poética de Hilda Hilst: a tensão explicitada pelo dualismo que se institui de várias formas. Estas formas, nutridas por um subjetivismo singular, permitem que se repense uma proposta de lírica, edificada nos vários tempos, promovendo um desdobramento provocador para a crítica, no que se refere ao status da tradição do gênero lírico e do pensamento a esse respeito, que se concretizou a partir da modernidade literária.

É preciso, antes de mais nada, principalmente quando se trata da obra de Hilda Hilst, falar com prudência sobre a concepção de gêneros. A ideia de gênero como "ordem" estabelecida, mesmo aos moldes dos clássicos, apresenta instabilidade de conceitos. Dizer que poesia é um texto, cujas estruturas e disposição são feitas em versos nem sempre a define como lírico, no sentido de expressão de um eu que se individualiza e expressa um estado de pensamento ou de sentimento.

\footnotetext{
${ }^{15}$ HILST, Hilda. Moderato Contabile. In: Júbilo, memória, noviciado da paixão. São Paulo: Globo, 2003, p. 56.
} 
Por este motivo, é importante relembrar que a poesia lírica era julgada gênero menor pela visão clássica. Para Aristóteles, o épico e o dramático eram os dois "grandes gêneros", por serem entendidos como ficção e imitação das vivências humanas, e como tal se ancoravam na ficcionalidade e nas histórias contadas em terceira pessoa e representadas em versos. O lírico não se incluía nesta perspectiva, porque apresentava uma imagem falsa da realidade, revelando emoções individuais, portanto, na primeira pessoa, cuja expressão de sentimentos se pautava no estado anímico.

A concepção de "grandes gêneros" modifica-se com o advento do Romantismo, quando o narrativo abre-se em várias facetas denominadas prosa; este fato propiciou a ascensão e o reconhecimento do romance como forma literária, substituindo a forma, em verso, da epopeia. Uma das muitas implicações dessas mudanças foi a instauração do verso como expressão da forma do poema. O lírico passa, a partir de então, a ser encarado de outra forma, o que imprimiu um remanejo do conceito e nesse remanejo a poesia acentuou a emergência de subjetividade.

Afirma-se comumente que a lírica, como forma peculiar de poesia, pode operar tanto em formas poemáticas, tais como a ode, o rondó, a cantiga, o soneto, quanto em formas de versificação livres. Além disso, pode também haver poesia em outras formas ou espécies de textos, como é o caso da prosa poética, do poema em prosa, poema de verso livre, entre outros. Aristóteles, em Poética, limita-se a desenvolver um entendimento sobre o narrativo e o dramático, negligenciando, até certo ponto, a definição clara de poético como gênero. Yves Stalloni (2007) conclui em seus estudos sobre os gêneros literários que o poético é visto como "gênero incerto"16. Essa expressão de incerteza também significaria uma "desordem” na concepção da categoria do lírico, que

\footnotetext{
${ }^{16}$ Do livro Os gêneros literários de Yves Stalloni. "Um gênero incerto" é o título do capítulo 4 (p.129), que trata sobre a poesia e o gênero lírico.
} 
se estende até os dias de hoje. Algo que ficou do pensamento aristotélico sobre os gêneros é que a lírica, feita para ser cantada, não toma como alvo unicamente o mundo como modelo porque é considerada espontânea, no sentido de ser vista como canto de introspecção individual, em que a fala do eu parece se dirigir a si mesmo. Neste ponto, é possível falar de subjetividade na lírica. Stalloni (2007, p. 129) estabelece como um dos critérios que contribuem para a concepção da poesia e do lírico, além do verso e da ficção, o critério da subjetividade. Subjetivo é a restrição de objetividade em sua forma narrada. Esta restrição:

responderá a uma relação pessoal das impressões suscitadas pelo mundo, uma exploração íntima dos sentimentos expressa através de uma voz julgada espontânea, que é o canto. Tomando-se ele próprio como assunto, o poeta abandona o domínio da imitação da realidade e troca daquele da introspecção individual. (STALLONI, 2007, p. 135).

Em se tratando de subjetividade lírica, os dois livros que compõem o volume Cantares propõem pontos de reflexão sobre o sentido de lírica como canto da alma, com todos os seus conflitos e suas indagações a respeito da vida e da constituição do ser. Entretanto, em Hilst, a elaboração verbal e a composição do conteúdo na obra são procedimentos que transpõem os meros registros do "estado de alma", de representação do "sublime". Os poemas que fazem parte de Cantares do sem nome e de partidas, em especial, evocam de forma mais contida a nomeação dos elementos convencionalmente vistos como próprios da lírica: questões de instabilidade, na linguagem, feita de contrastes entre a figura de Deus e do homem, da morte e do amor, retomadas e atualizadas por Hilst em seu discurso numa forma de lírica que se contrapõe, desde a modernidade, ao modo de pensar as estruturas do texto poético. Os primeiros versos do poema $\mathrm{V}$, que veremos na íntegra mais adiante, propõem um pensamento em relação aos temas e motivos cultivados pela modernidade de Edgar Alan Poe $^{17}$ :

\footnotetext{
${ }^{17}$ Edgar Allan Poe, um dos mais brilhantes escritores de uma geração que ajuda a afirmar a importância da literatura norte-americana do século XIX, era considerado o mestre do conto. Entre esses contos, publica "O Corvo" (1845), no qual apresenta a expressão nervermore - nunca mais.
} 
O Nunca Mais não é verdade.

Há ilusões e assomos, há repentes

De perpetuar a Duração

O Nunca Mais é só meia-verdade: [...]

(HILST, 2004, p.21)

Essas questões trazem à tona a atuação da voz lírica que expressa subjetividade e busca, no passado, elementos e temas possíveis de serem relidos de maneira nova. $\mathrm{O}$ fato de subscrever a expressão "Nunca Mais" - nervermore, do poema de Poe, não significa uma atitude de ratificação ou negação do $\operatorname{passado}^{18}$. É apenas uma maneira de transpor e sobrepor vozes líricas para darem formato ao tipo de subjetividade que a poesia de Hilst propõe. Desta forma, importa trazer para a reflexão, ou até contra a reflexão, o pensamento de Hegel sobre a lírica, para quem a poesia tem como marca principal um eu lírico subjetivo e opõe-se à objetividade épica. Por isso, a condição desta subjetividade consiste "no fato de assumir em si mesma inteiramente o conteúdo real e torná-lo seu" (HEGEL, 2004, p. 163). Neste caso, o mundo exterior, ou seja, o objeto sobre o qual se insere o texto, apresenta-se como pretexto para que o poeta lírico possa pinçar elementos que lhe são depurados pelo seu "estado de alma", e transformar em ficcionalização de maneira diferente da prosa.

A disposição interior do "eu" é configurada na exteriorização de si mesmo. Em Hilst, isso é percebido no momento em que a escolha do objeto é o próprio sentimento transformado em discurso que expressa uma subjetividade questionadora, por meio de imagens feitas de contrastes, causando tensão ao poema:

I

Vida da minha alma:

Recaminhei casas e paisagens

Buscando-me a mim, minha tua cara.

Recaminhei os escombros da tarde

Folhas enegrecidas, gomos, cascas

\footnotetext{
${ }^{18}$ Essa questão será melhor desenvolvida nas páginas mais adiante.
} 
Papéis de terra e tinta sob as árvores

Nichos onde nos confessamos, praças

Revi os cães. Não os mesmos. Outros

De igual destino, loucos, tristes,

Nós dois, meu ódio-amor, atravessando

Cinzas e paredões, o percurso da vida.

Busquei a luz e o amor. Humana, atenta

Como quem busca a boca nos confins da sede.

Recaminhei as nossas construções, tijolos

Pás, a areia dos dias

E tudo que encontrei te digo agora:

Um outro alguém sem cara. Tosco. Cego.

$\mathrm{O}$ arquiteto dessas armadilhas.

(HILST, 2004, p.33)

Neste poema de Cantares de perda e predileção, o substantivo "ódio-amor", criado pelo eu lírico, tem vasta gama de sentidos para a poesia de Hilst, neste e no primeiro livro de Cantares. Mesmo sendo precedido do pronome "meu", e de "nós dois", não representa unicamente alguém como seu interlocutor. Tal substantivo é parte primordial de um projeto de escrita, de um percurso traçado não aleatoriamente, mas arquitetado por um discurso que apenas "simula" falar sobre um desengano amoroso. Contudo, esse percurso se dilata pela busca incessante de nomeação do seu objeto de escolha: "Nós dois, meu ódio-amor, atravessando / Cinzas e paredões, o percurso da vida." O poema resulta da busca eterna de nomeação do amor e do desejo de materializálo: "Como quem busca a boca nos confins da sede". Uma busca que é construída paulatinamente pelas imagens criadas como "escombros da tarde", "Pás e areia dos dias". Essas imagens são representadas pelo sentimento do "eu" que quer comunicar algo em si. E essa comunicação em si, o eu lírico hilstiano a recolhe dos seus sentimentos mais profundos e transforma-os em imagens como expressão de subjetividade. "Buscando-me a mim, minha tua cara”, verso que representa o ponto alto da busca empreendida pelo eu 
lírico, uma busca da identidade individual, que se projeta na junção com o outro: "minha tua cara".

Ao pensar sobre a concepção de lírica, Hegel infere que o poeta lírico vê o objeto exterior, mas representa-o apenas pela intuição e sentimento. Desta forma, o poema lírico é, sobretudo, sua própria identidade e a grandeza dela que o poeta tem de expressar para si e tornar objetiva, de modo que ele se apodera por seu lado, do objeto, elabora-o interiormente, leva nele a si mesmo à exteriorização e, por isso, interrompe em autonomia livre o curso de desenvolvimento objetivo por meio de seu próprio sentimento ou reflexão, ilumina e altera-o subjetivamente e, desse modo, não deixa que predomine a coisa, mas o entusiasmo subjetivo preenchido por ele mesmo. Com isso temos, todavia, dois lados diferentes, sim, opostos: a potência arrebatadora do conteúdo e a liberdade poética subjetiva, que irrompe na luta com o objeto que quer dominar. (HEGEL, 2004, p. 185). ${ }^{19}$

Em Hilst, nos Cantares, o eu lírico resgata o objeto exterior que é o próprio sentimento, mas não o vê de forma intuitiva. A elaboração do objeto poético necessita não só da emoção e experiências individuais da poeta, mas também incita um "outro" como se fosse a metade de si, em: "Buscando-me a mim, minha tua cara", e no primeiro verso da última estrofe, no uso da forma pronominal "te": "E tudo que encontrei te digo agora". Esse verso retoma uma espécie de chamamento feito no primeiro verso "Vida de

\footnotetext{
${ }^{19}$ A visão totalizante de pensamento de Hegel prevê que a partir do conceito emana a realidade. Essa ideia é trazida para esta tese para volatizar a compreensão da gênese de lírica. Márcio Scheel, em sua tese de doutorado, assim apresenta: "Hegel é um dos principais representantes do Idealismo Absoluto alemão e foi ele quem pôs em circulação a noção metafísica de que são as ideias que, em última instância, fundam a realidade. Para tanto, desenvolveu uma dialética totalizante e teleológica, que privilegiava a criação de um sistema fechado de pensamento, capaz de promover, de forma rigorosa, essa síntese desejada e proposta. Foi justamente por esse ideal de sistema, essa busca por uma forma totalizante e integradora do pensamento e da ideia que fundam a realidade que Hegel se tornou um dos maiores combatentes da aventura poética e filosófica aberta pelos primeiros românticos alemães e sua busca pela conciliação entre poesia e filosofia por meio do fragmento literário, que desarticula ou torna impossível qualquer forma sistemática e teleológica de representação do pensamento. Hegel propõe o inverso dos românticos, faz um caminho contrário ao propor o resgate do classicismo greco-latino como um modelo sistêmico, a monumentalidade greco-latina, a transcentalidade da arte greco-latina. Hegel rejeita o niilismo romântico, que se afirma como abertura para um processo de negação, rejeição, ruptura e descontinuidade em relação aos modelos e paradigmas formais estabelecidos pelo pensamento clássico." (SCHEEL, UNESP-Araraquara, 2009, p. 286)
} 
minha alma", uma forma de expressão de subjetividade preocupada com a comunicação lírica por ele sugerida.

O percurso traçado pelo eu lírico que move o poema, um percurso feito mais de uma vez, indicado pelas palavras "Recaminhei", repetida por três vezes e por "Revi”, no primeiro verso da segunda estrofe, resgata um status de subjetividade, que não se configura apenas na expressão de experiências individuais, mas constitui-se em tensão, como retomada e crítica de si que também se endereça ao outro. $\mathrm{O}$ eu refaz o percurso para olhar o outro - que é o "arquiteto". É por causa "dele" que o eu se engana. Nesse caso, parece haver uma batalha com o Sublime. Vemos que todo o poema é uma preparação para a queda desse Sublime, que se dá na última estrofe. Na busca do outro está também a busca de si, já que esse outro é imaterial.

Desse modo, o eu hilstiano refaz e empreende, como sugere Hegel acerca da lírica, a "luta com o objeto que quer dominar", ou seja, a busca incessante de nomeação desse objeto: o amor, ou o "ódio-amor": "Busquei a luz e o amor. Humana, atenta / como quem busca a boca nos confins da sede". A relação metonímica "boca" e "confins da sede" expressa o máximo da intensificação da busca empreendida pelo eu lírico em externar o objeto. Assim, no processo de elaboração, encontra-se a experiência entre o sensível e o inteligível. Essa é a condição de ser do texto poético, e que se manifesta ao longo dos tempos de forma diferente.

A partir do período romântico, retomando o que foi mencionado anteriormente, a representação da subjetividade que compõe o gênero lírico modifica sua condição de “subgênero" ou de "gênero menor". Desde então, o termo poesia aproxima-se mais de lírica, escrita em versos; até que, ao longo do século XIX, o verso puro afasta-se de sua condição clássica em detrimento do verso livre e do poema em prosa. Neste ponto, há a ruptura da hegemonia das formas fixas na arte poética. A poesia também deixa de ser 
mera expressão de emoções e experiências individuais e constitui-se subjetivamente como uma teoria, uma história ou uma crítica de si mesma.

Para refletir um pouco mais sobre a relação entre a subjetividade do eu lírico e seu objeto e para delinear caminhos de entendimento sobre a lírica hilstiana, trazemos o pensamento do "sujeito lírico fora de si", expressão que Michel Collot utiliza para denominar o sujeito da lírica da modernidade. Segundo o autor, ao sair de si, o poeta projeta-se para a exterioridade e nesse movimento há uma tensão do "dentro" e do "fora" por meio da emoção lírica:

Pelo menos desde Platão, sabe-se que o sujeito lírico não se possui, na medida em
que ele é possuído por uma instância ao mesmo tempo a mais íntima de si e
radicalmente estrangeira. Essa possessão e esse desapossamento são
tradicionalmente referidos à ação de um Outro, quer se trate, no lirismo místico ou
erótico, de um deus ou do ser amado, no lirismo elegíaco, à ação do Tempo, ou ao
chamado do mundo que arrebata o poeta cósmico. Essa ação não se separa da que
exerce o próprio canto, que mais se apodera do poeta do que dele próprio emana.
(COLLOT, 2004, p. 165).

O movimento de tomar posse e de desapossar-se de si faz com que o eu lírico reveja os seus sentimentos e pensamentos modificados no momento da expressão ao outro. A esse respeito, importa lembrar também que o texto lírico, na esteira de Emil Staiger, em Conceitos Fundamentais da Poética (1975, p. 57), deve "mostrar o reflexo das coisas e dos acontecimentos na consciência individual”. Entretanto, o mesmo autor afirma que os conceitos se confundem, pois “os objetos não são presos em si e a imagem de 'dentro' e 'fora' provém da imagem de uma representação de câmara escura com que se figura a essência do homem” (p. 57-8). Neste caso, o sentido de 'disposição anímica' apresentado por Staiger não é nada que exista 'dentro' do eu, e sim 'fora', porque permite ao poeta não estar diante do objeto, mas nele. Significa dizer que esse estar no objeto implica a diluição do mundo interior e exterior e os dois tornam-se um só, o um-no-outro.

Entre Collot e Staiger, dadas as diferenças, é possível encontrar um fio de diálogo estabelecendo o lírico. Ambos tratam da relação dos elementos extrínsecos e intrínsecos 
como movimento necessário para que o poético se constitua. E a "saída de si” do sujeito lírico, o não expressar apenas as suas emoções individuais, empresta à poesia de Hilda Hilst sua mais íntima significação, no que se refere à atuação desse sujeito projetado em Outro, que pode ser o seu interlocutor. A poesia, segundo a própria poeta, é "escapar da emoção, fazer com que a emoção se desprenda da emoção cotidiana. E é algo além da emoção. Ela é um modo de disciplinar o dizer amoroso". ${ }^{20}$

Retomando ainda o poema I, nos versos: "Busquei a luz e o amor. Humana, atenta/ Como quem busca a boca nos confins da sede" (2004, p. 33), a expressão "Humana, atenta", conota tensivamente um eu despojado daquele sentimentalismo centrado apenas em si, mas do eu que sente com o raciocínio e apreende, "do fora", seu eu por meio de um outro eu. Este outro nem sempre é um ser ficcional, representa também outros lugares e tempos. Com eles a poeta dialoga para constituir o seu "eu" e, a partir desse procedimento, constitui uma poesia crítica de si, no sentido de colocar-se, em tensão, entre o objeto a ser expressado e a reflexão sobre o modo como se expressa. Dizendo de outro modo, uma disciplina do "dizer amoroso". O subjetivismo parece, neste caso, diluir o tom confessional de um lirismo apenas romântico, sem, contudo, abdicar a visão de mundo interior.

A poesia de Hilda Hilst problematiza conceitos da tradição, e materializa-os, como se fosse possível retornar ao princípio das coisas para nomeá-las e renomeá-las, de maneira a elidir e, ao mesmo tempo, validar um tipo de subjetivismo que, desapossado do tom apenas confessional, reelabora seus temas e motivos. No poema VII de Cantares do sem nome e de partidas, é perceptível este tipo de procedimento poético:

\footnotetext{
${ }^{20}$ Entrevista recolhida e organizada por Cristiano Diniz em Fico besta quando me entendem, entrevistas com Hilda Hilst. São Paulo: Globo 2013. PISA, Clelia \& PETORELLI, Maryvonne Lapouge. "Brasileiras: voux , écrits du Brésil." Paris: Des Femmes, 1977. Tradução de Marcela Vieira.
} 
Rios de rumor, meu peito te dizendo adeus.

Aldeia é o que sou. Aldeã de conceitos.

Porque me fiz tanto de ressentimentos

Que o melhor é partir. E te mandar escritos.

Rios de rumor no peito: que te viram subir

A colina de alfafas, sem éguas e sem cabras

Mas com a mulher, aquela,

Que sempre diante dela me soube tão pequena.

Sabenças? Esqueci-as. Livros? Perdi-os.

Perdi-me tanto de ti

Que quando estou contigo não sou vista

E quando estás comigo veem aquela

(HILST, 2004, p.23).

As formas de dicção comunicativa encontram-se expressas no verso "Aldeia é o que sou. Aldeã de conceitos" e são uma espécie de chave de entendimento para os demais versos, por conotar um discurso que esconde uma suposta simplicidade e parece relativizar conceitos, como se fosse fácil, assim, definir a experiência e a subjetividade poética. Neste sentido, retomemos Collot, para quem a saída de si do sujeito lírico é uma regra para que a expressão aconteça: “o sujeito lírico só virá a ser si mesmo através da forma realizada do poema, que encarna sua emoção, em uma matéria que é ao mesmo tempo do mundo e das palavras" (2004, p.167). Este pensamento desdiz, até certo ponto, o tipo de lirismo em que o eu se faz à mercê de seus sentimentos, como pensa Hegel. Entre esses dois tipos de subjetivismo, o que vê o exterior como pretexto para expressar o estado de alma e o que desapossa o sujeito de si para pertencer ao mundo e a linguagem, está o lirismo de Hilst. O eu, ora chama a atenção para si, ora sai de si para se encontrar no outro. Desta forma, a lírica de Hilst apresenta um tipo diferente de subjetividade de um lirismo apenas imanente, porque transforma-se em "outro-em-si"; ao se projetar para fora, volta para si transformando-se em outro, como no verso: "Que quando estou contigo não sou vista /E quando estás comigo veem aquela." Neste caso, a presença do sujeito amado é ponto fundamental para que aconteça a linguagem.

Neste sentido, chamamos a atenção para a maneira como Hilst mobiliza ações interlocutivas em sua lírica. Os procedimentos de construção poética no poema citado 
contribuem para que se constitua um tipo de alteridade, no qual o "eu" apreende do outro a sua emoção e intimidade, por meio do modo como se refere ao outro. Esse outro, muitas vezes, não é somente o amado, mas a performance lírica que traz, no processo de criação e por meio do diálogo, novas configurações. A palavra "rumor", por exemplo, em combinação com "rios" confere musicalidade ao verso e arrasta o discurso por meio do "r" à tradição e à memória da forma de canto da lírica. Esse movimento de volta à tradição não é muito tranquilo, assim como o rio não flui naturalmente; é um rio rumoroso, que propõe uma disposição afetiva, referindo-se a sentimentos individuais exteriorizados em imagens sentenciadas pelo sofrimento pela não realização do amor, em “... meu peito te dizendo adeus..." e pela impossibilidade de conceituar o signo da despedida, em: "Porque me fiz tanto de ressentimentos / Que o melhor é partir e te mandar escritos”. Vê-se, dessa forma, a expressão da incompletude amorosa que se esvai com a despedida. Mas o que fica é a obra, são os “escritos".

Um dado interessante é que neste poema parecem intensificar-se as indagações do eu sob a ótica do outro, ou seja, sobre a imagem de outro eu, uma espécie de contraposição a sua própria face, mas que não existe sem o seu oposto. Seria uma espécie de unidade dualista, cuja segunda persona, a que supostamente foi criada, impõe-se sobre a primeira: "Mas com a mulher, aquela / Que sempre diante dela me soube tão pequena". Assim como o sentido de 'disposição anímica' de que fala Staiger, o eu lírico expressa-se não somente pela via do "dentro", mas transmuta-se no objeto por meio do "outro", tornandose um só. O eu lírico se anula perante a "outra" e isso faz com que se invertam os papéis: o eu passa a ser a outra, "aquela": "Perdi-me tanto em ti / Que quando estou contigo não sou vista / E quando estás comigo veem aquela". Por fim, ao criar outra imagem, o eu lírico sai de si e adere à noção de prisão versus liberdade, em que a "outra", a imagem 
vista como seu duplo, não pertence ao amado, porque ela não tem corpo, é apenas espírito, ou um ser ficcional.

E, com o pensamento assim proposto, podemos dizer que sua poesia se insere no modo de encarar a subjetividade lírica da modernidade apregoada desde meados do século XIX e afirmada, principalmente, por Charles Baudelaire. O subjetivismo romântico se despersonaliza, conforme comenta Hugo Friedrich a respeito da poesia de Baudelaire (1978, p. 36): “com Baudelaire começa a despersonalização da lírica moderna, pelo menos no sentido que a palavra lírica já não nasce da unidade de poesia e pessoa empírica, como haviam pretendido os românticos". E acrescenta: "Quase todas as poesias de Les Fleurs du Mal falam a partir do eu. Baudelaire é um homem completamente curvado sobre si mesmo. Todavia este homem voltado para si mesmo, quando compõe poesias, mal olha para seu eu empírico" (Idem, p. 37).

Esse pensamento de Baudelaire, segundo Friedrich, faz refletir sobre questões de subjetividade que envolvem a poesia da modernidade. É na modernidade do século XIX que toda a reflexão a respeito do conceito de poesia vem à tona com maior força. É fato que Charles Baudelaire dá o tom novo à lírica, porque insere em seu pensamento uma proposta modificada de explicar as coisas pelo viés divino, que passa a ver a poesia mais como expressão do que como conteúdo. O pensamento de Baudelaire a respeito da poesia, analisado por Hugo Friedrich em seu livro A estrutura da lírica moderna, é o de que o poeta constrói uma nova realidade, na qual se torna possível definir a poesia como "recriação da linguagem, o que equivale ao rompimento da tessitura linguística" (FRIEDRICH, 1991, p.151). Ainda, para este autor, não haveria modernidade sem Baudelaire, pois ele é um dos criadores dessa palavra. O formato da poesia moderna ligase diretamente a Baudelaire, para quem o artista moderno expressa, de forma particular, a "capacidade de ver no deserto da metrópole não só a decadência do homem, mas 
também de pressentir uma beleza misteriosa não descoberta até então" (FRIEDRICH, 1991, p. 35). Para Baudelaire, a modernidade vai além de ver a metrópole como um dado negativo de diluição do homem em detrimento da máquina; ele vê a negatividade de modo dissonante e, ao mesmo tempo, fascinante: “o mísero, o decadente, o mau, o noturno, o artificial, oferecem matérias estimulantes que querem ser apreendidas poeticamente. Contêm mistérios que guiam a poesia a novos caminhos" (FRIEDRICH, 1991, p. 43).

Contudo, em vez de "novos caminhos" talvez fosse interessante dizer "diferentes caminhos" através dos quais a poesia da modernidade se constrói. O poema XXXIX de Cantares de perda e predileção, ao falar de amor, propõe uma forma "rara" de lírica. Nela a experiência poética se configura na expressão do que é novo:

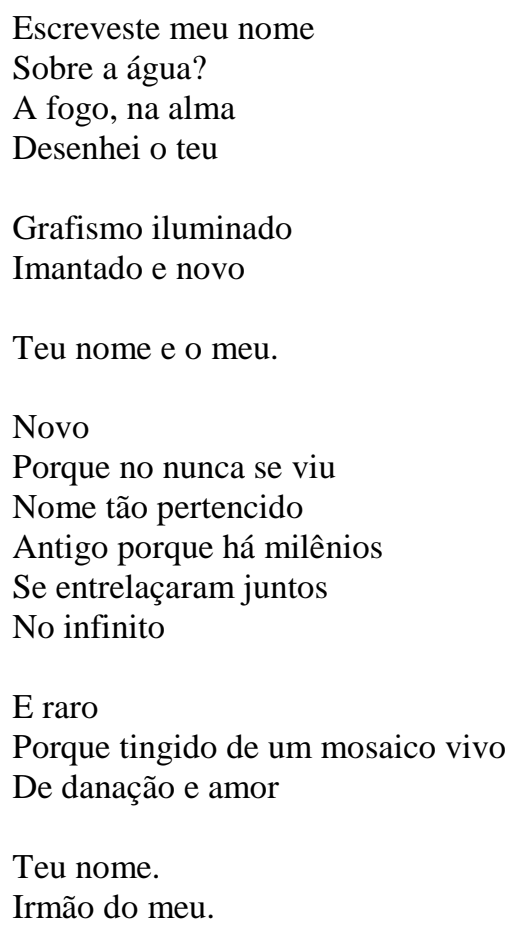

(HILST, 2004, p 73.)

A noção de subjetividade neste poema se inscreve de maneira a pinçar o novo das formas do antigo. E isso se faz pela escrita do poema, predisposta no primeiro verso. Uma escrita que não é feita "sobre a água" porque, assim, ela se desfaz facilmente no momento 
em que é realizada, mas uma escrita desenhada a fogo, na alma. Tem-se um eu falando com o interlocutor "tu". Essa escolha do tratamento em segunda pessoa, o "tu", sugere um tipo de proximidade e de intimidade em reação ao "eu". Tal processo íntimo pode indicar tanto a representação de uma relação amorosa, como a relação do poema com sua escrita, que infere ideia de "novo", algo nunca visto, de "antigo", porque ambos, os nomes, o amor e a escrita, para a poesia lírica, sempre estiveram entrelaçados. Finalmente, algo "raro", porque sua constituição se apresenta como um "mosaico vivo" em que o antigo e o novo estão imbricados. Nesse "mosaico vivo", “danação”, um termo disfórico, aparece ao lado de "amor". Os adjetivos "novo", "antigo" juntam-se em uma só significação, de forma a criar uma tensão de sentidos e constituir o "raro".

A lírica de Hilst, nesses versos instaura-se como uma crítica de si, o que pode colocá-la em sintonia com o estatuto da poesia pós-romântica. Ao mesmo tempo em que nos versos da segunda estrofe, "Grafismo iluminado / Imantado e novo" e na terceira, "Teu nome e o meu", percebemos uma relação amorosa, essa atmosfera amorosa estabelece um eu lírico que se desapossa do sensível romântico, porque a junção de "Teu nome e o meu" nomeia o "mosaico vivo" e, por isso, não há uma única versão para a subjetividade lírica. Assim, a poesia de Hilda Hilst constrói-se, nestes versos, de forma a desapossar o estatuto do antigo e do novo, aderindo a um subjetivismo individualizador do eu lírico, cujo papel é o de exteriorizar o sentimento do amor em que o sensível e o inteligível passam a ser comunicáveis.

Dentre as várias tensões que o poema em tela propõe por meio da imagem “mosaico vivo", uma delas situa-se na relação do eu lírico com o proposto interlocutor. Vejamos: apenas os versos "Escreveste meu nome"; "Grafismo iluminado"; "Nome tão pertencido"; "Se entrelaçaram juntos"; "De danação e amor", são hexassílabos, eles marcam um ritmo e com isso apresentam uma sequência inteligível de constituição lírica. 
Se pensarmos no verso "Se entrelaçaram juntos" como uma atitude apenas romântica de relação amorosa estaremos dirimindo o verdadeiro sentido poético do verso, isto é, a constituição da forma de dizer hilstiana que, neste mesmo verso, apresenta-se, gradativamente, por meio de tensões, o eu no outro.

É possível ver essa tensividade nos poemas de Cantares, não só com relação aos pressupostos da lírica da modernidade, mas também com relação aos da tradição clássica. Ao recolher das formas de versificação clássicas de lírica elementos para construir seu discurso, a poeta busca mais uma forma de interlocução com a tradição desses aspectos formais, como veremos, nas baladas, odes, árias, cantos, trovas, elegias, sonetos, de maneira a aglutinar formas da tradição numa espécie de desconstrução e reconstrução dessas formas.

Os versos "Grafismo iluminado / Imantado e novo" instalam, de forma "rara" a inscrição do novo reconstruído: o eu lírico cria um diálogo com um interlocutor que pode ser o amado, expressado pela relação entre "teu nome" e o "meu", desenhado a fogo, na alma. Dizendo de outra forma, sempre vai haver, na poesia, um eu para expressar ao ouvinte/leitor um estado de espírito. O que pode mudar é a performance desse eu no momento da materialização do discurso. Ao ler aspectos da lírica da modernidade na poesia de Hilst, propõe-se um certo tipo de eu/sujeito 21 "diferente", dado o fato de que, retomando o pensamento de Baudelaire, a lírica moderna liquefaz os pilares da tradição lírica e dá preferência a temas disfóricos a ela. No próximo tópico, será abordado mais de perto como isso se dá na reunião Cantares.

O termo "eu/sujeito" aparece aqui, desta forma, para definir a ambivalência de sentido com que a poesia de Hilst trabalha a subjetividade do eu lírico, e sua relação com o sujeito lírico da modernidade. Há, neste caso, uma sobreposição de um no outro. 


\subsection{Dos Cantares}

Os dois livros do volume Cantares $^{22}$ (2004) - "Cantares do sem nome e de partidas" de 1995 e "Cantares de Perda e Predileção" de 1983 - seguem ordem cronológica inversa de publicação. É como se essa disposição dos livros sugerisse uma espécie de reafirmação da obra poética de Hilst: o que está dito no seu último livro reitera o que já havia sido dito mais de uma década antes, no anterior. Esse procedimento reafirma o modo de fazer da poesia de Hilda Hilst, que adota o caminho da repetição, do ofício que a poeta tem em dizer o que quer dizer, como se repetir fosse uma retomada de consciência discursiva e esse procedimento usado como um artifício para expressar-se.

A leitura do livro pode suscitar vários tipos de diálogos, além dos já mencionados nesta pesquisa, e permite refletir sobre um traço marcante na experiência poética da autora: a tensão explicitada pelo dualismo que se apresenta de várias formas. A saber, a forma dual, começando pelo título do livro, justifica-se pela possível relação entre a forma “cantares" e os cânticos do livro bíblico (conforme sugere Alcir Pécora em "Nota do Organizador" ao livro Cantares, 2004, p.7). Com essa relação entre o livro de Hilst e o livro bíblico, é pertinente afirmar que os dois livros da reunião delimitam um espaço amoroso de perdas e partidas e celebram a união dos esposos de forma nada amena, conforme afirma Alcir Pécora, ocorre uma “celebração sensualíssima das núpcias trocada por um registro de batalhas e lutas" (PÉCORA, 2004, p. 7).

Esses enfrentamentos do amante em relação ao amado manifestam-se num discurso também carregado de paradoxos. Isto não ocorre no livro da Bíblia. "Cantares de Salomão" ou "Cântico dos cânticos"23 é um poema lírico escrito para exaltar as

\footnotetext{
${ }^{22} \mathrm{O}$ título da reunião foi dado por Alcir Pécora, organizador da obra de Hilda Hilst, pela editora Globo.

${ }^{23}$ Essa denominação de título varia de edição para edição. A que me refiro encontra-se na edição "Ave Maria" citada na bibliografia geral e adota o título "Cântico dos cânticos". O Livro Cantares de Salomão também apresenta o título Cântico dos Cânticos, este é considerado um superlativo, ou seja, serve para indicar que este é o melhor dos cantares. Salomão provavelmente escreveu esse cântico durante a primeira parte de seu reinado. Isso colocaria a data de composição por volta de 965 A.C. O Livro é um poema lírico
} 
virtudes do amor entre o esposo e sua esposa. Expressa uma atitude harmônica entre um homem e uma mulher, que devem viver juntos no contexto do casamento, amando um ao outro espiritualmente, emocionalmente e fisicamente. Neste livro bíblico, considerado o mais belo cântico do rei Salomão, há uma voz que exalta o amor numa relação de confluência pacífica entre os amados: "Ah! Beija-me com os beijos de tua boca! /porque os teus amores são mais deliciosos do que o vinho, / e suave é a fragrância de teus perfumes; / o teu nome é como um perfume derramado: / por isto amam-te as jovens. / Arrasta-me após ti; corramos!” (1957, p. 826). Este livro apresenta-se, ainda, como se fosse um único poema escrito para exaltar o amor também em seu estado espiritual: "porque o amor é forte como a morte," e "As torrentes não poderiam extinguir o amor / nem os rios o poderiam submergir" (1957, p. 834, cap. 8, vers. 6 e 7).

O livro de Hilda Hilst, sobretudo o que compõe a primeira parte de Cantares, constitui-se igualmente, como se fosse um único poema, porque, além de seus versos se entrelaçarem poema a poema, estes também se unem ao segundo livro da reunião, formando um único constructo que trata do amor, em presença e ausência, trabalhado de maneira conflituosa, revestido pelo tom do lamento de um amante que sofre pela falta do amado, e, configurado, este, em várias identidades.

Desta forma, o espaço metafórico em que os versos se apresentam é o do diálogo às avessas com a forma do livro bíblico, pois não há neles uma situação de equilíbrio, e sim de angústia que questiona conceitos e tudo o que pode ser considerado imutável, colocando em evidência a busca de nomeação dos sentimentos. Uma das expressões desse

escrito para exaltar as virtudes do amor entre um esposo e sua esposa. O poema claramente apresenta o casamento como um plano de Deus. Um homem e uma mulher devem viver juntos dentro do contexto do casamento, amando um ao outro espiritualmente, emocionalmente e fisicamente. Este livro combate dois extremos: o ascetismo (a negação de todo o prazer) e hedonismo (busca do prazer somente). A poesia deste livro toma a forma de um diálogo entre um marido (o rei) e sua esposa (a Sulamita). http://www.gotquestions.org/Portugues/Livro-Cantares-Salomao.html 
estado de conflito discursivo encontra-se nos versos abaixo, do poema III, de Cantares do sem nome e de partidas, cuja análise será desenvolvida no decorrer deste capítulo. Por ora, vejamos a última estrofe do poema:

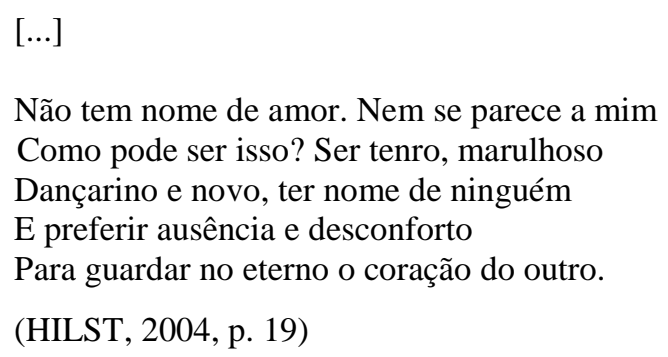

Não há, nesses versos, uma definição objetiva dos sentimentos expressos. Os signos de negatividade "não" e "nem" impermeabilizam uma resposta clara aos questionamentos. O estar perto não significa nada, só a ausência solidifica a plenitude, e o eterno é feito pela ausência do amado. Assim, a noção de amor é aquela da ordem do conflito em que o sujeito lírico ${ }^{24}$ se desapossa de sua visão apenas intuitiva e traz para reflexão tensiva os elementos extrínsecos e intrínsecos. É o que veremos, a seguir, no primeiro livro da reunião Cantares.

\subsection{Dos Cantares do sem nome e de partidas}

Cantares do sem nome e de partidas, o primeiro livro do volume Cantares, apresenta a maturidade da produção de Hilda Hilst, por ser seu último livro inédito publicado. Este pode ser considerado como um único poema, divido em dez partes/poemas, ligados uns aos outros por encadeamentos de ideias que propõem

\footnotetext{
${ }^{24}$ Até aqui foi utilizado o termo "eu" lírico para se referir ao eu da poesia de Hilst. Neste caso, a utilização do termo "sujeito" lírico refere-se à condição de lírica na modernidade, na qual este ser criado pelo poeta apresenta atitude ativa diante da criação e dialoga com o interlocutor/leitor e com o próprio texto, fazendo com que estes saiam do estado de passividade e contemplação clássicas. Neste caso, o sujeito lírico de Hilst faz a relação dele com o mundo e com o outro, mas acaba voltando para si mesmo.
} 
unicidade à obra. Nesse único poema revela-se o manejo de sua experiência poética adquirida ao longo dos anos. Quando lançado, em 1995, Jorge Coli assim o descreveu:

\begin{abstract}
Mais recente, seu "Cantares do Sem Nome e de Partidas" retoma um caminho meditativo. São dez poemas curtos que se encadeiam, formando núcleos que adquirem uma quase autonomia, mas cujo sentido maior se dá na relação que mantêm entre si. (COLI, Folha de São Paulo, 14/06/1996).
\end{abstract}

Os poemas que compõem este livro traçam, de fato, um "caminho meditativo" sobre a construção da imagem do amor, tema caro à lírica de todos os tempos. Hilst canta, neste seu último livro de poesia, de forma dolorosa, os sentimentos de partida: "a vida que esmorece" $" 25$, e a consciência de sua obra: o "texto-desengano" 26 , numa incessante luta interior do sujeito consigo mesmo, na eterna busca do amor pleno.

O livro é um projeto de escrita, cujas pistas de leitura foram sendo deixadas pela poeta no decorrer de sua criação, quer pelas dedicatórias, quer pelas epígrafes, quer pela disposição dos versos que constituem o todo da obra. O título do livro traz em si o signo da despedida, tomando-o como algo que não se explica racionalmente: "sem nome", e que pode ser lido de várias formas: uma reflexão sobre o amor, que se apresenta em ausência, ou a constatação de ser o último livro publicado pela autora, que nele encerra o trabalho de criação.

Os poemas de Cantares do sem nome e de partidas evocam de forma mais contida, a nomeação dos elementos próprios da lírica: questões de instabilidade do ser humano na linguagem, feita de contrastes entre a figura de Deus e do homem, da morte e do amor, que Hilst tematiza, retoma e atualiza em seu discurso, por meio das escolhas, da combinação dos signos e da maneira de se constituírem como texto poético. As pistas

\footnotetext{
${ }^{25}$ Parte do verso do poema IX de Cantares (2004, p.25): "E quando pensas VIDA QUE ESMORECE. E retomas"

26 “Teu balbucio trêmulo, teu texto-desengano". Idem.
} 
para a leitura começam pela dedicatória: a André Pinotti e à memória de Mirella Pinotti, que morreu jovem, vítima de um acidente automobilístico nos arredores de Campinas. ${ }^{27}$ Constituem pista também as epígrafes, uma do poeta português Luís Vaz de Camões e outra de John Webster. Na primeira, os versos: “Ó tirânico Amor, ó caso vário/ Que obrigas um querer que sempre seja/ De si contínuo e áspero adversário...”, integram a écloga 28 “Almeno e Agrário, pastores”. Este poema de Camões é marcado por uma voz queixosa que faz vários tipos de evocação, a saber: (“Ó tempo já passado, tão presente / te vejo abertamente na vontade". "Ó imatura morte, que a ninguém / de quantas vidas tem nunca perdoas!”. “Ó estranha inconstância e tão profana/ de toda a cousa humana inferior.". "Ó doce pensamento, ó doce glória!” "ó que triste sucesso foi de amores”. "Ó tirânico amor, ó caso vário. $)^{29 "}$ (os destaques são meus). Veremos que as invocações feitas nestes versos de Camões parecem relacionar-se com o tom que Hilda Hilst dá aos poemas do livro, pela invocação ao amor que se faz sempre em contrastes: “...um querer que sempre seja / De si contínuo e áspero adversário..."

\footnotetext{
${ }^{27}$ Conforme Folha de São Paulo. São Paulo, segunda-feira, 3 de julho de 1995. Mirela Pinotti era filha do deputado José Aristodemo Pinotti, medico obstetra, reitor da Unicamp, também pai do médico André Pinotti. Essa família era muito conhecida em Campinas.
}

\footnotetext{
${ }^{28}$ Segundo o Dicionário de Termos Literários de Carlos Ceia, écloga ou égloga é um poema em forma de diálogo ou de solilóquio (articulação lógica do pensamento), sobre temas rústicos, cujos intérpretes são em regra pastores. Inicialmente, o termo foi aplicado aos poemas bucólicos de Virgílio. A partir daí, aplica-se às pastorais e aos idílios tradicionais que Teócrito e outros poetas sicilianos escreveram. Outros poetas italianos como Dante, Petrarca e Boccaccio recuperaram o género, que acabaria por se tornar um dos preferidos dos poetas renascentistas e maneiristas europeus. A grafia égloga, popularizada por Dante, parte de uma falsa etimologia latina que derivava de aix ("cabra, bode") e logos ("palavra", "discurso", "diálogo"). De acordo com o comentário irónico do poeta inglês Spencer, em "E. K.", terá sido construída para significar algo como "Goteheards tales" (contos de cabreiros). Luís de Camões e outros poetas portugueses nos legaram poemas do gênero. As suas composições seguem os modelos clássicos, não existia até então qualquer teorização portuguesa sobre as éclogas. A rigor, nem os modelos clássicos (Horácio e Diomedes) teorizam em particular sobre a écloga. $\mathrm{O}$ que sabemos sobre as regras da écloga advém dos próprios textos. No caso português, só em 1605, Francisco Rodrigues Lobo teoriza sobre o assunto em Discurso sobre a Vida e o Estilo dos Pastores (1605). Os poetas árcades do século XVIII ainda exploram o gênero, tendo mesmo teorizado sobre a écloga, como Dinis da Cruz e Silva. Um dos melhores intérpretes da écloga nesta época é João Xavier de Matos, destacando-se Albano e Damiana (1758). Disponível: http://www.edtl.com.pt/index.php?option=com mtree\&task=viewlink\&link id=944\&Itemid=2

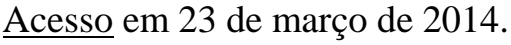

${ }^{29}$ O poema completo está no endereço eletrônico: http://www.jornaldepoesia.jor.br/camoes37.html. 
A segunda epígrafe: "Cubram-lhe o rosto, meus olhos ofuscam-se;/ ela morreu jovem", é de John Webster, um dramaturgo inglês, contemporâneo de Willian Shakespeare, que escreveu sua obra no início do século XVII. Entre suas obras estão as tragédias "O Diabo branco" e a "Duquesa de Malfi"30. Esta epígrafe, tomada por Hilst, faz pensar em duas possibilidades: a primeira, a relação de seu conteúdo com a dedicatória à Mirella Pinotti, que morreu jovem; a segunda, como metáfora de despedida da poeta com seu público. Basta pensar em "meus olhos ofuscam-se”, como uma luz que se esvai.

Os autores dessas epígrafes são ícones de épocas diferentes, mas tratam do mesmo objeto, o amor. Na primeira, um amor bem aos moldes camonianos, conflituoso no tema e no discurso; ávido de explicações para os deslimites do pensamento humano no que se refere ao amor. A segunda sugere a referência ao "morrer de amor", expressão máxima da individualidade lírica romântica e também da tragédia clássica. Esses elementos aparecem imbricados e muitas vezes retorcidos nos poemas do livro de Hilst. Vejamos:

\title{
I
}

\author{
Que este amor não me cegue nem me siga. \\ E de mim mesma nunca se aperceba. \\ Que me exclua do estar sendo perseguida \\ E do tormento \\ De só por ele me saber estar sendo \\ Que o olhar não se perca nas tulipas \\ Pois formas tão perfeitas de beleza \\ Vêm do fulgor das trevas. \\ E o meu Senhor habita o rutilante escuro \\ De um suposto de heras em alto muro. \\ Que este amor só me faça descontente \\ E farta de fadigas. E de fragilidades tantas \\ Eu me faça pequena. E diminuta e tenra \\ Como só soem ser aranhas e formigas. \\ Que este amor só me veja de partida.
}

\footnotetext{
${ }^{30}$ La Duquesa de Malfi, original de John Webster (Londres, 1580-1630), es la obra clásica que no firma Shakespeare más representada en los escenarios anglosajones. Relata la historia de una aristócrata que se casa en secreto con su mayordomo, enfrentándose por ello a sus hermanos. Estos se vengan desarrollando hasta límites casi cómicos la idea de crueldade. Disponível em: http://www.elcultural.es/version_papel/ESCENARIOS/29735/La_duquesa_de_Malfi_y_Juanra_Bonet Acesso em 24 de março de 2014.
} 
(HILST, 2004, p.17)

Neste poema, há uma série de aspectos constitutivos da linguagem que merecem atenção. A começar, o demonstrativo "este" refere-se ao objeto próximo ao falante, ou ao que acaba de ser dito - "este amor" - que remete à relação de profunda intimidade do "eu" com este referente temático proposto na obra. O fato de "este amor" vir precedido do pronome "que" dá ao verso um tom optativo e sugere a não intenção de definir o amor de uma única maneira. Os sentidos já estão postos no modo como se dispõem os versos, tanto que a expressão anafórica "Que este amor" se repete no início de cada estrofe. A construção "cegue", que é idêntica, foneticamente, a "segue", constitui uma dupla sonora com "siga". As sibilantes nos dois verbos, cegar e seguir, instauram, neste verso, um movimento que lembra o ir em frente, mesmo às cegas, e é, ao mesmo tempo, interrompido pelas negativas "não" e "nem", quebrando a fluidez do ritmo: "Que este amor não me cegue nem me siga.”. O segundo e terceiro versos: "E de mim mesma nunca se aperceba", "Que me exclua do estar sendo percebida" reforçam a negação pela forma "nunca", o que infere, já desde o início, um movimento de desapego ao amor cantado pelo viés apenas do sensível, do "tormento", em profundidade. Todavia, o movimento de desapego também se desloca para uma reafirmação, num ritmo contínuo marcado pelo verbo no gerúndio: "De só por ele me saber estar sendo".

O verso seguinte, "Que o olhar não se perca nas tulipas", como o primeiro e o terceiro, inicia-se com a forma optativa "que”, e expressa o desejo de que algo se realize, no caso, que seu discurso não se perca, não seja vão. Novamente há referência ao cantar o amor de forma diferente. A palavra "tulipas" 31 , no sentido e na forma de beleza, como

\footnotetext{
${ }^{31}$ Tulipa é uma flor selvagem oriunda da Pérsia. O seu nome, porém, é turco e a sua semelhança com turbante (Tulbend), usado pelos homens na Turquia. São formadas por uma única flor em cada haste, com folhas alongadas, apresentando seis pétalas ou na forma com pétalas dobradas, podendo atingir de 30 a 60 $\mathrm{cm}$ de altura.
} 
as tulipas, que crescem "escondidas" antes da floração, realça tanto as tensões provocadas pela expressão da beleza, encontradas no “...fulgor e trevas", como a ideia de uma beleza que se faz da relação entre claro e escuro, luz e sombra, lembrando o jogo de ideias dos tons do barroco, tensionados nestes versos de Hilst. E essa relação parece remeter a uma desconfiança da beleza do amor, porque esta beleza provém não da escuridão das trevas, mas do "fulgor das trevas" ou do "rutilante escuro".

"Este amor", cantado nos versos do poema, sugere a desconstrução do sentido de magnificência e perfeição, dos versos do "Cântico dos Cânticos": "Põe-me como um selo sobre o teu coração, / como um selo sobre os teus braços; / porque o amor é forte como a morte, a paixão é violenta como o $\operatorname{cheol}^{32}$ / Suas centelhas são centelhas de fogo / uma chama divina" (1957, p. 834. Cap. 8, vers. 6). Este sentido de amor parece não ser o mesmo no poema de Hilst. Os versos da segunda estrofe demonstram que "este amor" tem sentido disfórico em relação aos do livro bíblico, porque causam descontentamento. Os sentidos de amor são encadeados, no poema, pelo polissíndeto "e", que também se apresenta de forma gradativa, porque sugere um movimento de diminuição do ser perante o amor: "E de mim mesma nunca se aperceba"; "E farta de fadigas. E de fragilidades tantas / [...] E diminuta e tenra”. O processo de repetição da conjunção “e”, nesses versos, dá a ideia de mitigação gradativa da identidade humana, ao desembocar em símbolos de animais, "Como só soem ser aranhas e formigas", bichos rasteiros que podem ser identificados aqui como a pequenez do ser, ou, ainda, como forma de negação do homem.

\footnotetext{
Uma lenda conta que a tulipa negra teve origem no drama de uma jovem persa que nutria um grande amor por um jovem de sua região, porém, seu amor não era correspondido e ao ser rejeitada, a jovem fugiu para o deserto e desesperada chorava muito. Conta a lenda que em cada local da areia onde caia uma lágrima, nascia uma tulipa negra. Disponível em: http://www.significados.com.br/tulipas/Acesso em $03 \mathrm{de}$ abril de 2014.

${ }^{32}$ Segundo definição que consta no livro Cântico dos Cânticos, (1957, p. 834), cheol significa "habitação dos mortos".
} 
A condensação lírica no verso “Que este amor só me faça descontente” propõe um tipo de subjetividade que expressa o conflito do eu lírico em relação ao que se tenta conceituar como amor. Esse conflito remete à epígrafe camoniana, um "tirânico amor", “áspero e adversário" de si. Neste ponto, há uma construção lírica que faz o movimento de sair de si e, ao mesmo tempo, voltar a si, como continuidade de um eu, sempre nesse trânsito.

A última estrofe, composta por apenas um verso, retoma o primeiro verso do poema $^{33}$, ao mesmo tempo em que anuncia o início do poema II: "E só me veja"34. Importa pensar nesse procedimento de retomada como um dado interessante de continuidade. A palavra "só", nos dois versos, propõe dubiedade de sentidos. Apesar de ser um elo entre os dois poemas, ela pode ser lida, no poema I, como advérbio, projetando nele o signo da despedida. No primeiro verso do poema II, a ideia que se tem é tanto a de solidão, ou do abandono, quanto a de unicidade, reforçada no segundo verso: que este amor apenas deveria ser visto "No não merecimento das conquistas". Segue o poema:

II
E só me veja
No não merecimento das conquistas.
De pé. Nas plataformas, nas escadas
Ou através de umas janelas baças:
Uma mulher no trem: perfil desabitado de carícias.
E só me veja não no merecimento e interdita:
Papéis, valises, tomos, sobretudos
Eu-alguém transvestida de luto. (E um olhar de púrpura e desgosto, vendo através de mim navios e dorsos)
Dorsos de luz, de águas mais profundas. Peixes.

\footnotetext{
${ }^{33}$ Esse tipo de retomada é chamado de leixa-pren: antigo artifício poético, que consistia em começar uma estrofe pela palavra ou frase, em que terminou a estrofe anterior. Esta repetição pode se dar não com a retomada literal de palavras, mas com a retomada de um mesmo núcleo semântico Do Gal. port. (deixaprende, isto é, larga e retoma). http://pousio.blogspot.com/2009/02/vestigios-do-leixa-pren-na-poesia.html\#ixzz454euHXoU
}

34 Uma técnica próxima do leixa-pren. Esse procedimento de linguagem acontece em todos os poemas deste Cantares do sem nome e de partidas. 
Mas sobre mim, intensas, ilhargas juvenis

Machucadas de gozo.

E que jamais perceba o rocio da chama:

Esse molhado fulgor sobre o meu rosto.

(HILST, 2004, p.18)

No poema há uma relação intrínseca entre o signo da "partida" e o signo do "ver", que configuram modos diferentes do olhar: "E só me veja" remete a um olhar que vê através de uma superfície opaca, de passagem: "De pé. Nas plataformas, nas escadas /Ou através de umas janelas baças:”. O ver pela penumbra, que não define muito bem alguém "transvestido de luto", imagem do eu da poeta que sugere a ausência não só de quem olha, no caso, o outro, o amado, mas também de quem é olhado, o eu, o amante.

A poeta cria uma segunda pessoa, uma espécie de segundo eu, um alter ego, que vê a si próprio e, de forma amargurada, a dor de estar partindo. A visão de ver a si no "não merecimento e interdita" remete ao silenciar-se ou, fazendo um jogo sonoro e semântico, ao interdito, dito por dentro, que não se expõe; um discurso vindo do interior, recluso, movido pelos signos expostos no último verso da segunda estrofe: "Papéis, valises, tomos, sobretudos". Neste verso, misturam-se os elementos de produção da arte, papéis e tomos, e os do partir, valises, sobretudos, como se todos os sentidos fossem uma coisa só, confluídos num mesmo constructo discursivo.

O sentido de "só" percorre o poema movido pelo signo do adeus. O verso "Uma mulher no trem: perfil desabitado de carícias" remete a um eu que parte, mas com sentimento contido de solidão e abandono, vendo na partida a possibilidade de perpetuar sua imagem. Vejamos a terceira estrofe:

\footnotetext{
Eu-alguém transvestida de luto. (E um olhar de púrpura e desgosto, vendo através de mim navios e dorsos)
} 
O eu lírico apresenta-se "em si”, pois vê o mundo através de si e manifesta-se em outro. O um-no-outro. Neste caso, o grau de 'disposição anímica' compreendida por Staiger propicia uma compreensão do eu lírico hilstiano nos versos acima. Este, não somente está diante do objeto, mas nele, e o mundo é visto através dele. O outro, que também é um “eu-alguém” criado por Hilst em sua poesia, é a saída para a compreensão de sua identidade lírica. Desta forma, o sujeito se constitui em uma relação íntima com a alteridade, na qual o eu, o mundo e a linguagem são recíprocos.

É pertinente retomar a reflexão sobre a lírica e a atuação do sujeito em si ou fora de si como um problema a ser digerido na poesia de Hilst. Se, para Hegel, o eu se projeta para fora para expressar a subjetividade e, para Collot, o sujeito sai do "dentro" para não pertencer mais a si, e sim ao mundo e à linguagem, a peculiaridade, no caso da lírica de Hilst, está exatamente no movimento de exteriorização do eu para realizar-se no outro, mas sem perder o domínio de si, porque o outro criado nesse processo é visto em ausência, ou em partida. Logo, o eu não perde o domínio de si, porque acaba voltando para si. Dizendo de outro modo, o eu de Hilst não é contemplativo, isto é, sua poesia contém um tipo de subjetividade diferente do lirismo de "pura imanência", porque este tipo de eu lírico se transforma no outro-em-si, como nas expressões destes versos: "Eu-alguém transvestida de luto $[\ldots]$ vendo através de mim $[\ldots] "$

O "olhar de púrpura e desgosto[...]" que vê através do signo "luto" sugere a referência a alguém que fica e a alguém que está partindo. Neste caso, a ausência tem duplo sentido. Uma ausência que pode ser do "amado" e também do "amante". A palavra "dorsos", que termina o terceiro verso da terceira estrofe e inicia a estrofe seguinte, anuncia a saída e ao mesmo tempo o mergulho em si do eu lírico, no sentido de partida, de deixar para trás a materialidade e a sensualidade: "Mas sobre mim, intensas, ilhargas juvenis / Machucadas de gozo". Nos dois últimos versos do poema, temos novamente 
uma oração optativa em que a ideia de gozo se materializa pelas imagens "rocio da chama" e "molhado fulgor": "E que jamais perceba o rocio da chama:/ Este molhado fulgor sobre meu rosto". Há, nesses dois versos, as marcas da mais bela sensualidade como forma de amor carnal. Vemos a maneira como o eu lírico de Hilst lida com a emoção, e a expressão "este molhado fulgor" apresenta o grau de sentimentalidade externado no rosto e, antecedido pelo pronome "este", que será identificado no poema III pelo "Isso": "Isso de mim que anseia despedida".

III

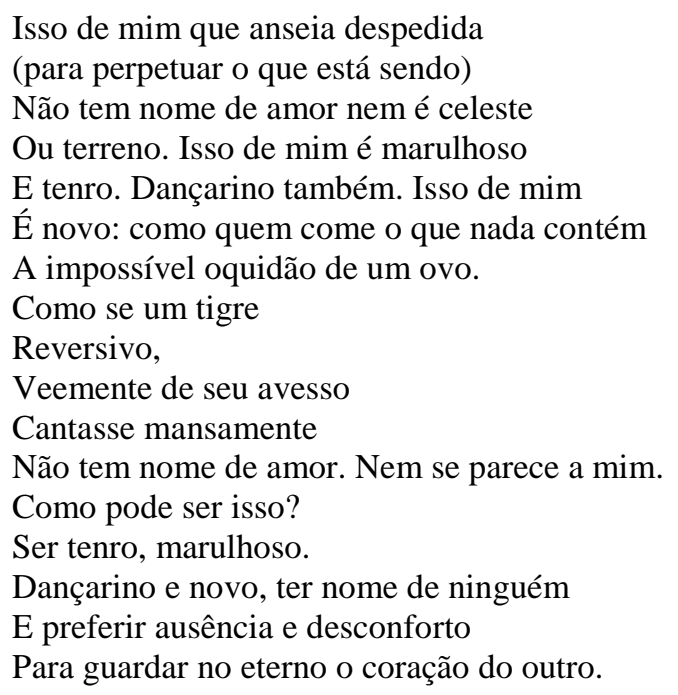

(HILST, 2004, p.19).

Cantares do sem nome e de partidas é um livro que instala, de forma mais reflexiva, a busca da explicação para as coisas. A forma como estas questões são cantadas coaduna a impossibilidade de dar resposta às indagações da alma. Dizendo de outra maneira, a poesia de Hilst se coloca no intervalo entre a contemplação e o raciocínio, na tentativa de definir questões indefiníveis sobre o homem e o mundo, o amor e a morte.

Neste poema, há um esvaziamento de conceitos que se desdobram em outras facetas do que "não tem nome", metaforizados pelo movimento pendular entre o nada e 
o tudo, materializados numa outra configuração: o corpo em movimento do qual emana o fazer poético, que é também o corpo do poema. A expressão inicial, "Isso de mim", repete-se por mais duas vezes: "Isso de mim que anseia despedida", [...] "Isso de mim é marulhoso", "E tenro e dançarino também. Isso de mim". O pronome demonstrativo "isso" aparece duas vezes com tons afirmativos nos primeiro e quarto versos; acompanhado de "de mim", adquire uma significação interessante para a construção lírica: o sentimento expresso por um eu que "sai de si" para referir-se imediatamente ao seu interlocutor, dado que o pronome "isso" indica algo que se encontra afastado do falante e perto do ouvinte. Na terceira vez, o pronome aparece interrogando o ouvinte: “Como pode ser isso?”, e sugere algo indefinível. Entretanto, ele pode também significar uma retomada do que foi dito anteriormente. Na verdade, essa é uma constante da obra de Hilst: a construção consciente, por meio de imagens antitéticas, de nomeação, revestida dos sentimentos que a compõem, tais como o amor, o ódio e a inquietação.

O movimento da dança “E tenro. Dançarino também. Isso de mim”, que pode ser um movimento de circularidade e repetição, permite pensar numa tentativa de nomear o "novo" ou fazê-lo nascer: "A impossível oquidão de um ovo" ou "É novo: Como quem come o que nada contém". Esse movimento da dança reforça ainda a percepção de continuidade discursiva entre os versos e os poemas de todo este primeiro livro da reunião Cantares.

A experiência poética aqui está pautada na busca do eterno, por meio da ausência que vive o ser em suas emanações e transfigurações. Um ser inquieto com seu estar no mundo; o "isso de mim", ao mesmo tempo vazio e pleno de conflitos, busca no coração do outro a sua edificação e só terá nome se for guardado no eterno. Há, neste caso, a essência e a substância metaforizadas em "ovo", imagem que remete ao nascimento da 
forma lírica, como se a poeta tentasse nomear, mas essa nomeação lhe escapasse, porque ela é feita de ausências e de partidas.

O "Isso de mim", além de ser "marulhoso", "tenro", "novo" também pode ser "doloso", conforme segue, no primeiro verso do poema IV:

IV

\author{
E por que, também não doloso e penitente? \\ Dolo pode ser punhal. E astúcia, logro. \\ E isso sem nome, o despedir-se sempre \\ Tem muito de sedução, armadilhas, minúcias \\ Isso sem nome fere as feridas. \\ Pertinente e algoz: \\ Como se só na morte abraçasse a vida. \\ É pomposo e pungente. Com ares de santidade \\ Odores de cortesã, pode ser carmelita \\ Ou Catarina, ser menina ou malsã. \\ Penitente e doloso \\ Pode ser o sumo de um instante. \\ Pode ser o tu-outro pretendido, teu adeus, tua sorte \\ Fêmea-rapaz, ISSO sem nome pode ser o todo \\ Que só se ajusta ao Nunca. Ao Nunca Mais. \\ (HILST, 2004, p.20).
}

O sentido da palavra "doloso" predito neste primeiro verso vem reforçar a forma como a poeta expressa o signo da despedida: uma manobra discursiva e astuta para “enganar" o menos avisado que pensa o "isso de mim" apenas como alguma coisa que causa sofrimento. "Dolo pode ser punhal. E astúcia, logro". Mas o "isso" é sem nome e pode ser um todo, como nos últimos versos. Para chegar à ideia do todo, há uma construção retórica, argumentativa, da construção do poema. Primeiro, a enumeração do que pode ser o "isso": "Isso sem nome fere as feridas", como o despedir-se, que se constitui de elementos opostos: penitente e algoz, santidade e cortesã, tu-outro, fêmearapaz. Esses aspectos discursivos contribuem para uma tessitura da teia em que o eu lírico se enreda. Isso se faz presente, no poema, pela locução “pode ser”, repetida por três vezes, 
na última estrofe. A locução reforça a noção de doloso da primeira estrofe, isto é, de lograr e de jogar de forma enganosa e camaleônica com os sentidos e as definições do "isso de mim".

A última estrofe inicia-se por um tipo de quiasmo deslocado do primeiro verso do poema: da interrogação “doloso e penitente?" para a afirmação "Penitente e doloso". Essa construção propõe interlocução provocativa com um interlocutor que não pode mais ser passivo, porque as respostas não estão prontas. Isso nos faz refletir sobre a atuação do eu lírico hilstiano: ele instiga seu leitor, convida-o ao diálogo, dá-lhe pistas de compreensão, mas, ao mesmo tempo, ele próprio já tem as respostas na busca de conceitos para um “isso" cuja resposta está em processo de formação; algo "Que só se ajusta ao Nunca. Ao Nunca Mais”, que é negado, em seguida, com o primeiro verso do poema V:

\section{$\mathrm{V}$}

O Nunca Mais não é verdade.

Há ilusões e assomos, há repentes

De perpetuar a Duração.

O Nunca Mais é só meia-verdade:

Como se visses a ave entre a folhagem

E ao mesmo tempo não.

(E antevisses

Contentamento e morte na paisagem).

O Nunca Mais é de planícies e fendas.

É de abismos e arroios.

É de perpetuidade no que pensas efêmero

E breve e pequenino

No que sentes eterno.

Nem é corvo ou poema o Nunca Mais.

(HILST, 2004, p.21).

A construção lírica deste poema remete a uma espécie de visita ao passado, rememorado por elementos do poema "O Corvo" de Edgar Alan Poe ${ }^{35}$. O artifício de

\footnotetext{
${ }^{35}$ Alguns críticos da obra de Hilda Hilst já chamaram a atenção para este recurso utilizado pela autora neste poema, pois a questão salta aos olhos. É o caso de Cantares de encontros, partidas e contradições (uma leitura de Cantares, de Hilda Hilst), de Vera Maria T. SILVA. Contudo, julguei pertinente recorrer a esses apontamentos, acrescentando reflexões que ainda precisam ser mencionadas nos estudos sobre esta questão em Hilda Hilst.
} 
composição poética adotado retoma o refrão do poema de Poe pela expressão "Nunca Mais", com iniciais maiúsculas; aparece de forma aleatória no poema, infringindo a forma do refrão, mas associando-se ao seu sentido de recorrência. Essa expressão não é negação ou recusa, mas estabelece-se como um "logro" ao passado que está no tempo presente da obra e recolhido na poesia de Hilst não como uma verdade absoluta, mas sim na relatividade de conceitos expressos no poema. Esse procedimento se faz como um misto de aceitação e negação, porque são apenas indícios ou aparências da "verdade" da obra de Poe. Há, nessa relação entre as duas obras, proposta por esse poema, uma espécie de interlocução que relativiza a ideia do que está posto como verdade: “O Nunca Mais não é verdade".

A primeira estrofe retoma o poema de Poe não só pela expressão substantivada do "Nunca Mais", mas também pela menção à "a ave", que não vem pela janela, como no poema de Poe, mas “entre as folhagens". O passado, neste caso, é visto de forma não muito clara pelo sujeito lírico, que o vê "E ao mesmo tempo não". ${ }^{36} \mathrm{O}$ mito do corvo

\section{${ }^{36} \mathrm{O}$ CORVO}

Numa meia-noite agreste, quando eu lia, lento e triste, / Vagos, curiosos tomos de ciências ancestrais, /E já quase adormecia, ouvi o que parecia / O som de alguém que batia levemente a meus umbrais. /"Uma visita", eu me disse, "está batendo a meus umbrais./ É só isto, e nada mais."

Ah, que bem disso me lembro! Era no frio dezembro, /o fogo, morrendo negro, urdia sombras desiguais./Como eu qu'ria a madrugada, toda a noite aos livros dada / P'ra esquecer (em vão!) a amada, hoje entre hostes celestiais - / Essa cujo nome sabem as hostes celestiais, / Mas sem nome aqui jamais!

Como, a tremer frio e frouxo, cada reposteiro roxo / Me incutia, urdia estranhos terrores nunca antes tais!/ Mas, a mim mesmo infundido força, eu ia repetindo, "É uma visita pedindo entrada aqui em meus umbrais; -/ Uma visita tardia pede entrada em meus umbrais. / É só isto, e nada mais".

E, mais forte num instante, já nem tardo ou hesitante, / "Senhor", eu disse, "ou senhora, decerto me desculpais; / Mas eu ia adormecendo, quando viestes batendo, /Tão levemente batendo, batendo por meus umbrais, /Que mal ouvi..." E abri largos, franqueando-os, meus umbrais. /Noite, noite e nada mais.

A treva enorme fitando, fiquei perdido receando, / Dúbio e tais sonhos sonhando que os ninguém sonhou iguais. / Mas a noite era infinita, a paz profunda e maldita, / E a única palavra dita foi um nome cheio de ais - /Eu o disse, o nome dela, e o eco disse aos meus ais. /Isso só e nada mais. 
Para dentro então volvendo, toda a alma em mim ardendo, / Não tardou que ouvisse novo som batendo mais e mais. /"Por certo", disse eu, "aquela bulha é na minha janela. /Vamos ver o que está nela, e o que são estes sinais." /Meu coração se distraía pesquisando estes sinais. / "É o vento, e nada mais."

Abri então a vidraça, e eis que, com muita negaça, / Entrou grave e nobre um corvo dos bons tempos ancestrais. / Não fez nenhum cumprimento, não parou nem um momento, / Mas com ar solene e lento pousou sobre os meus umbrais, / Num alvo busto de Atena que há por sobre meus umbrais, /Foi, pousou, e nada mais.

E esta ave estranha e escura fez sorrir minha amargura / Com o solene decoro de seus ares rituais. / "Tens o aspecto tosquiado", disse eu, "mas de nobre e ousado, / Ó velho corvo emigrado lá das trevas infernais! / Dize-me qual o teu nome lá nas trevas infernais." / Disse o corvo, "Nunca mais".

Pasmei de ouvir este raro pássaro falar tão claro,/ Inda que pouco sentido tivessem palavras tais. / Mas deve ser concedido que ninguém terá havido / Que uma ave tenha tido pousada nos meus umbrais, /Ave ou bicho sobre o busto que há por sobre seus umbrais, / Com o nome "Nunca mais".

Mas o corvo, sobre o busto, nada mais dissera, augusto, /Que essa frase, qual se nela a alma lhe ficasse em ais. /Nem mais voz nem movimento fez, e eu, em meu pensamento /Perdido, murmurei lento, "Amigo, sonhos - mortais / Todos - todos já se foram. Amanhã também te vais". /Disse o corvo, "Nunca mais".

A alma súbito movida por frase tão bem cabida, /"Por certo", disse eu, "são estas vozes usuais, Aprendeu-as de algum dono, que a desgraça e o abandono / Seguiram até que o entono da alma se quebrou em ais, /E o bordão de desesp'rança de seu canto cheio de ais / Era este "Nunca mais".

Mas, fazendo inda a ave escura sorrir a minha amargura, /Sentei-me defronte dela, do alvo busto e meus umbrais; / E, enterrado na cadeira, pensei de muita maneira / Que qu'ria esta ave agoureia dos maus tempos ancestrais, / Esta ave negra e agoureira dos maus tempos ancestrais, /Com aquele "Nunca mais".

Comigo isto discorrendo, mas nem sílaba dizendo / À ave que na minha alma cravava os olhos fatais, Isto e mais ia cismando, a cabeça reclinando / No veludo onde a luz punha vagas sobras desiguais, Naquele veludo onde ela, entre as sobras desiguais, / Reclinar-se-á nunca mais!

Fez-se então o ar mais denso, como cheio dum incenso / Que anjos dessem, cujos leves passos soam musicais. / "Maldito!", a mim disse, "deu-te Deus, por anjos concedeu-te / O esquecimento; valeu-te. Toma-o, esquece, com teus ais, /O nome da que não esqueces, e que faz esses teus ais!" / Disse o corvo, "Nunca mais".

"Profeta", disse eu, "profeta - ou demônio ou ave preta! / Fosse diabo ou tempestade quem te trouxe a meus umbrais, / A este luto e este degredo, a esta noite e este segredo, /A esta casa de ância e medo, dize a esta alma a quem atrais /Se há um bálsamo longínquo para esta alma a quem atrais! / Disse o corvo, "Nunca mais".

"Profeta", disse eu, "profeta - ou demônio ou ave preta! Pelo Deus ante quem ambos somos fracos e mortais. / Dize a esta alma entristecida se no Éden de outra vida / Verá essa hoje perdida entre hostes celestiais, / Essa cujo nome sabem as hostes celestiais!" / Disse o corvo, "Nunca mais".

"Que esse grito nos aparte, ave ou diabo!", eu disse. "Parte! / Torna á noite e à tempestade! Torna às trevas infernais! / Não deixes pena que ateste a mentira que disseste! / Minha solidão me reste! Tira-te de meus umbrais! / Tira o vulto de meu peito e a sombra de meus umbrais!" / Disse o corvo, "Nunca mais".

E o corvo, na noite infinda, está ainda, está ainda/ No alvo busto de Atena que há por sobre os meus umbrais. / Seu olhar tem a medonha cor de um demônio que sonha, / E a luz lança-lhe a tristonha sombra no chão há mais e mais, / Libertar-se-á... nunca mais!

(Traduzido por Fernando Pessoa, ritmicamente conforme com o original) Disponível em: 
como ave que traz más notícias é negado no poema hilstiano, porque infere um significado diferente daquele da tradição moderna encontrado na obra do poeta norte-americano. "O Nunca Mais não é verdade.” e "O Nunca Mais é só meia-verdade”. A esse respeito, SILVA, (2009, p. 128), comenta que o primeiro verso do poema hilstiano "nega o caráter absoluto da dor da perda, o abatimento eterno e inexorável que acomete a voz lírica do poema de Poe, porque também esse sentimento de luto é paradoxal como o amor". No poema de Poe, a dor da perda da amada Lenora é intensificada pela presença do corvo; em Hilst, essa dor não é significante, nele sobressai-se a reelaboração dos temas e motivos da modernidade de Poe. Além disso, os índices de sentidos do corvo propostos por Poe, percebidos no poema de Hilst, aparecem de maneira a colocar em dúvida se eles estão mesmo no poema ou não, como se vê no último verso: "Nem é corvo ou poema o Nunca Mais". Esses sentidos aparecem nos versos: "Como se visses a ave entre as folhagens / E ao mesmo tempo não". A imagem estabelecida por esses versos contém um movimento de clareza e opacidade a respeito de seu sentido: "O Nunca Mais é só meia verdade”, "O Nunca Mais é de planícies e fendas"; as imagens criadas por meio das expressões "meia verdade" e "fendas" permitem perceber, parcialmente, o sentido dos elementos contidos no poema de Poe.

Os paradoxos se manifestam no poema todo: perpetuidade e efemeridade, breve e eterno. Esses pares geradores de negação e aceitação colocam a poesia de Hilst no status que torna possível perceber a dicotomia tensiva na poética da autora e na atuação do seu eu lírico. O poema de Hilst apresenta uma estrutura diferente da de Poe, porque ela reinventa, de maneira distinta, o termo nervermore; isto é, a poeta resgata esta expressão para agregá-la ao seu discurso, sem, contudo, chamar a atenção para si de forma explicitamente individualista. Enquanto para Poe o nunca mais (nervermore) é uma forma 
de o sujeito lírico dialogar com um interlocutor e expor seu estado anímico, em Hilst, essa recorrência se faz como um elo com o passado, convocando-o a dialogar, mas não há para isto uma subserviência ao sujeito lírico romântico. De maneira diferente, o interlocutor hilstiano está oculto pelos verbos "visses", “antevisses", "pensas" e "sentes", que fazem uma sequência significativa: ver, pensar e sentir. Tais sentidos configuram, na lírica da poeta, um caminho ativo de discernimento da realidade que sobrepõe o inteligível ao sensível, dramatiza o presente e escava o passado por meio da manipulação das palavras. O poema em questão demarca este discurso paradoxal pela reelaboração do passado, o romantismo, cujos traços são encontrados no poema "O corvo" de Alan Poe. ${ }^{37}$ O último verso de Hilst, "Nem é corvo ou poema o Nunca Mais", reverbera outro sentido ao poema, que não o dado por Poe. Este verso estabelece uma reflexão da ordem da autoconsciência poética hilstiana: a impossibilidade de nomear, apresentada neste poema pela substantivação da expressão "Nunca Mais", propõe não só a reconfiguração do termo usado por Poe, mas reforça a atitude de negação da verdade absoluta personificada, aqui, pela expressão dos aspectos originados do poema de Poe. Neste sentido, o eu lírico em Hilst se constitui pela relação que faz com as formas já ditas, e as dilui, tornando-as outra realidade poética, nascida do movimento de afirmação e negação do passado da modernidade.

Não é por acaso que este poema se localiza gráfica e tematicamente na parte central do livro; é para chamar a atenção para si, porque todos os poemas de Cantares aqui analisados estão ligados tanto no nível da linguagem como no nível dos motivos e

\footnotetext{
37 “O Corvo", publicado em 1845, representa o que há de melhor na poesia de Poe, com elementos estéticos bastante refinados, como musicalidade apurada, métrica perfeita e rimas complexas. Sua temática é repleta de morbidez e melancolia, envolvendo os temas mais comuns da segunda geração romântica, como a noite, o medo, a solidão, o sobrenatural, o mistério e a morte. Todos esses temas dão vida a uma obra-prima da literatura americana, que influenciou uma geração de escritores e remodelou as bases do gênero terror.
} 
temas pelo fio de um sujeito conflituoso que quer dar nome ao "isso", ao "sem nome" que pode ser visto como o amor ou a despedida. No poema VI, esse ciclo parece fechar-se:

VI

Tem nome veemente. O Nunca Mais tem fome.

De formosura, desgosto, ri

E chora. Um tigre passeia o Nunca Mais

Sobre as paredes do gozo. Um tigre te persegue.

E perseguido és novo, devastado e outro.

Pensas comicidade no que é breve: paixão?

Há de se diluir, molhaduras, lençóis

E de fartar-se,

O nojo. Mas não. Atado à sua própria envoltura

Manchando de quimeras, passeias teu costado.

O Nunca Mais é fera.

(HILST, 2004, p.21).

Novamente, neste poema uma voz canta a busca de nomear o "isso". Desta vez, valendo-se da voz do "Nunca Mais", materializado no ponto de vista físico e não espiritual, como no poema de Poe. O verso "Tem nome veemente. O Nunca Mais tem fome" conduz a nomeação para o aspecto erótico, configurado na forma de tigre ${ }^{38}$ : "Sob as paredes do gozo. Um tigre te persegue". Contudo, o poema retoma a figura de mansidão aparente, como no poema III "Como se um tigre / Reversivo, / Veemente de seu avesso / Cantasse mansamente”. (HILST, 2004, p. 19). A figura do tigre, como símbolo de potência e ferocidade, dá ao discurso o tom sensual de luta e combate à dor de representação do signo do adeus, ao mesmo tempo em que se humaniza com a beleza e a passividade: "De formosura, desgosto, ri / E chora. Um tigre passeia o Nunca Mais/

\footnotetext{
${ }^{38}$ El tigre evoca generalmente las ideas de potencia y de ferocidad; lo que no implica más que signos negativos. Es un animal cazador, y por ello símbolo de la casta guerrera. Tanto en la geomancia como en la alquimia china el tigre se opone al dragón; pero si en el primer caso es un símbolo nocivo, representa en el segundo un principio activo, la energía por oposición al principio húmedo y pasivo, el plomo por opasición al mercurio y el aliento por oposición al semen.(CHEVALIER; GHEERBRANT, 1986, p. 995.)
} 
Sobre as paredes do gozo". Parece haver uma relação de intimidade entre os dois, em que riso e choro se subvertem em gozo. Neste sentido, a referência ao Nunca Mais parece fechar um ciclo de procura à nomeação do amor e da partida, configurado pelas sensações de matéria e espírito, marcado pela imagem do animal felino, numa mistura do humano e do animalesco: "O Nunca Mais é a fera".

Os dez poemas contidos em Cantares do sem nome e de partidas formam um mosaico da poética de Hilda Hilst. Nele é possível ver o pensamento da poeta a respeito dos conflitos da vida, nos quais sempre buscou expressar na sua obra. Dizendo de outro modo, há uma realidade própria dessa lírica, não a que ela é, mas a que ela poderia ser, projetada em outro eu. Essa realidade permite que a poeta transponha a intimidade subjetiva para o plano do inteligível.

No poema VIII, há uma retomada deste outro "eu" e isso assim se configura:

VIII

Aquela que não te pertence por mais que queira

(Porque ser pertencente

É entregar a alma a um Cara, a de áspide

Escura e clara, negra e transparente), Ai!

Saber-se pertencente é ter mais nada.

É ter tudo também.

É como ter o rio, aquele que deságua

Nas infindas águas de um sem-fim de ninguéns.

Aquela que não te pertence não tem corpo.

Porque corpo é um conceito suposto de matéria

E finito. E aquela é luz. É etérea.

Pertencente é não ter rosto. É ser amante

De um Outro que nem nome tem. Não é Deus nem Satã.

Nem tem ilharga ou osso. Fende sem ofender.

É vida e ferida ao mesmo tempo, "ESSE"

Que bem me sabe inteira pertencida.

(HILST, 2004, p.24). 
Novamente temos, neste poema, o procedimento de repetição da palavra "aquela", em forma de anadiplose ${ }^{39}$, como elemento de unidade do livro de Hilda: o último verso do poema anterior "E quando estás comigo veem aquela" (poema VII, p. 23) é ratificado por "Aquela que não te pertence por mais que queira" (Poema VIII, p. 24. Os grifos são meus). "Aquela", diferentemente dos outros pronomes demonstrativos encontrados nos poemas anteriores, pode ser lido como substantivo, ou seja, pode referir-se a alguém cujo nome se ignora ou a algo que não se pode ou não se deve nomear. Metaforicamente, seria a imagem, ou a máscara utilizada pelo sujeito lírico que se projeta em outra pessoa, ficcionalizada.

Essas considerações remetem à noção de pertencimento e em consonância com a escassa liberdade do ser. Ambos, pertencimento e liberdade criam um fio tensivo entre pertencente e pertencida. Nos versos: "Saber-se pertencente é ter mais nada". "Pertencente é não ter rosto. É ser amante." e, "Que bem me sabe inteira pertencida", pertencente e pertencida se ligam pelo sensível e pelo inteligível e formam uma só carne e um só espírito. Há aqui a relação entre um duplo ser, o que não tem corpo, porque é feito de luz, e o que tem corpo, a pertencente, e a que é pertencida. Os versos "É vida e ferida ao mesmo tempo, "ESSE" / Que bem me sabe inteira pertencida" reforçam a noção de que "pertencida" se faz de desejos corpóreos e incorpóreos, porque é vida e ferida ao mesmo tempo e desemboca no ESSE, que tanto se busca nomear e parece ser feito de amor carnal e espiritual. A letras maiúsculas chamam a atenção para si, como que querendo dizer ou buscando nomear, de forma contundente, a aglutinação de todos os sentimentos a serem expressados no poema. E esse jogo de linguagem entre pertencida e

\footnotetext{
${ }^{39}$ Consiste na repetição da última palavra de um seguimento de verso ou de um membro da frase no início do seguinte: "Quero escrever sem saber, / Sem saber o que dizer." (Milano)O mau-humor produz a impaciência; da impaciência nasce à cólera; a violência; e a violência conduz ao crime. Disponível em: http://www.recantodasletras.com.br/gramatica/1960942. Acesso em 2 de abril de 2016.
} 
pertencente subjaz de uma relação íntima da atuação do eu lírico que se permite apossarse e desapossar-se de si para, e nesse movimento, criar um outro sem rosto, resultante da junção entre matéria e luz.

O penúltimo poema enfoca o sentido de despedida pela predominância de elementos que comprovam desejo carnal. Veremos como isso se dá no poema:

IX

Ilharga, osso, algumas vezes é tudo o que se tem.

Pensas de carne a ilha, e majestoso osso.

E pensas maravilha quando pensas anca

Quando pensas virilha pensar gozo.

Mas tudo mais falece quando pensas tardança

E te despedes.

E quando pensas breve

Teu balbucio trêmulo, teu texto-desengano

Que te espia, e espia o pouco tempo te rondando a ilha.

E quando pensas VIDA QUE ESMORECE. E retomas

Luta, ascese, e as mós vão triturando

Tua esmaltada garganta... Mas assim mesmo

Canta! Ainda que se desfaçam ilhargas, trilhas...

Canta o começo e o fim. Como se fosse verdade

A esperança.

(HILST, 2004, p.25).

Nos primeiros quatro versos, parece haver uma apologia ao corpóreo. A primeira palavra, "Ilharga", referente à quadril, carregada de sentidos sensuais, abarca um teor de magnitude, como se fosse uma ilha larga feita de "majestoso osso", que oferece gozo e prazer carnais. Os quatro primeiros versos organizam-se em afirmativas e se ordenam por meio de evidências sobre o despedir-se pelo aspecto do prazer carnal. O quinto verso iniciado pela adversativa "mas" remete a um desfazimento da matéria, do que é perecível e propõe que a vida e o tempo são fugazes, a matéria se desfaz, e tudo se transforma em pó. Nesse sentido, no décimo verso, há uma explicação para isso, numa definição para a vida em "caixa alta": "VIDA QUE ESMORECE”. Essa expressão remete ao primeiro verso do poema III: "Isso de mim que anseia despedida". O despedir-se da vida material 
aparece como inevitável, impossível de ser dominado sob a perspectiva do incorpóreo do ser.

Está evidente neste poema a interpelação que o eu lírico faz a um interlocutor, sobre a vida e o desaparecimento dela, pelos verbos e pronomes em segunda pessoa do singular. Há uma repetição do verbo pensar nas expressões "pensas”, (verso 2); “E pensas", (verso 3); "E quando pensas" (verso 7 e 11), distribuídas pelo poema desde o início, enfatizando que, gradativamente, esse pensar, ou seja, os aspectos trabalhados no poema devem ser considerados (pensados) e que o texto, mesmo sendo "textodesengano", precisa ser cantado, desencadeando lutas e batalhas: "Luta, ascese, e as mós vão triturando / Tua esmaltada garganta... Mas assim mesmo / Canta! Ainda que se desfaçam ilhargas, trilhas... / Canta o começo e o fim. Como se fosse verdade / A esperança". Aqui se vê o canto aflito de partidas, triturado pelas mós, buscando a ascese que é ao mesmo tempo recusa da plenitude do corpo e do espírito.

Não há como negar a interlocução com o oficio da escrita do poema, este ofício deve sobressair-se, como os oitavo e nono versos propõem: "Teu balbucio trêmulo, teu texto-desengano / Que te espia e espia o pouco tempo rondando a ilha”. Nestes versos há um apelo, como no carpe diem, a aproveitar a vida e continuar cantando, mesmo que este canto seja doloroso e esmagado pelas "mós" do tempo. Neste sentido, "Ainda que se desfaçam as ilhargas", ainda que a matéria se dilua com o tempo, o que sobra de tudo são os escritos.

Importante notar que o amor cantado neste livro, desde o início, é feito de ressentimentos. Assim, os signos da partida e da despedida são a solução para que a poesia se perpetue, como pode ser observado nos versos do poema VII: "Porque me fiz tanto de ressentimentos / Que o melhor é partir. E te mandar escritos” (HILST, 2004, p. 23).

E essa ideia continua no último poema do livro: 
$\mathrm{X}$

Como se fosse verdade encantações, poemas

Como se Aquele ouvisse arrebatado

Teus cantares de louca, as cantigas da pena.

Como se a cada noite de ti despedisse

Com colibris na boca.

E candeias e frutos, como se fosses amante

E estivesses de luto, e Ele, o Pai

Te fizesse porisso ${ }^{40}$ adormecer...

(Como se se apiedasse porque humana

É apenas poeira,

E Ele o grande Tecelão da tua morte: a teia).

Como se fosse vão amar, e por isso perfeito.

Amar o perecível, o nada, o pó, é sempre despedir-se.

E não é Ele, o Fazedor, o Artífice, o Cego

O Seguidor disso sem nome? ISSO...

$\mathrm{O}$ amor e sua fome.

(HILST, 2004, p.26).

O último poema do livro dá sequência à ideia de partida e de perpetuação da poesia, como busca de seu lugar "ao sol". Os últimos versos do poema IX, "Como se fosse verdade / A esperança", promovem o sentido de devir da poesia e são retomados (como de praxe neste livro) no primeiro verso do poema seguinte "Como se fosse verdade encantações, poemas". A ideia do vir a ser da poesia é reforçada pela repetição da expressão "Como se", que aparece por seis vezes, "como se" funcionasse como um balanço da escrita de Hilst, pois remete àquilo que poderia ter sido, como também à esperança do que ainda será.

Outra questão, no poema, é a retomada da despedida pelo símbolo da morte, como aspecto marcante à espreita, no livro todo. Basta lembrar a referência à morte na epígrafe de John Webster e na dedicatória à Mirella Pinotti. O poema parece se fechar num ciclo de vida e de criação artística pautada no canto ao amor, "esse" sem nome, que se relaciona contraditoriamente à vanidade e à perfeição, como no primeiro verso da

\footnotetext{
${ }^{40}$ A palavra é assim escrita também na primeira versão do livro, publicada pela Massao Ohno Editor, 1995.
} 
segunda estrofe: "Como se fosse vão te amar e por isso perfeito". E esse amor que a poeta canta desde o primeiro verso do primeiro poema, "Que este amor não me cegue nem me siga”, pode ser perecível e transformar-se em despedida: “Amar o perecível, o nada, o pó, é sempre despedir-se". A inter-relação entre a vida humana e a vida da poesia se concretiza pelos versos: "És apenas poeira" e a vida também se despede do poema, no verso, (como se) "Teu cantares de louca, as cantigas da pena. / Como se a cada noite de ti se despedisse".

Esse poema apresenta uma tentativa de interlocução com a morte e, principalmente com Deus. Sua construção é feita por um processo de encadeamentos, e, por meio desse procedimento nomeia Deus de Aquele, Ele, Pai, Tecelão, Fazedor, Artífice, Cego, Seguidor e culmina na relação tensiva entre o amor e Deus, pela qual se tenta explicar o "Isso", que, assim como o processo de nomear Deus, não pode também ter um único nome. Poderíamos dizer que o poema apresenta uma apologia a Deus e ao amor, o primeiro como gerador de tudo e o segundo, como fonte de busca eterna: "O amor e sua fome".

Conforme apresentado no início deste texto, os poemas do livro Cantares do sem nome e de partidas prefiguram um único construto; ligando-se por um fio em curtocircuito, tocam-se e se completam, tornando-se uma coisa só. Dentro dessa cadeia em que se constitui o livro, é possível notar um sujeito conflituoso, sem nome e sem certezas, que se apresenta em seus questionamentos pelos pronomes "este": "Que este amor não me cegue nem me siga" (poema I, p.17); "isso": "Isso de mim que anseia despedida" e "Como pode ser isso?" ( poema III, p. 19). Por fim, o ciclo traçado no livro todo permite chegar às mesmas indagações sobre a nomeação do "isso": "Como se fosse verdade encantações, poemas" (poema X, p. 26). A busca do sentido do amor e da despedida também se 
compara à busca de Deus como "o Fazedor, o Artífice, o Cego / O Seguidor disso sem nome? ISSO... / O amor e sua fome" (poema X, p. 26).

A construção do livro é feita em forma de espiral que ora se afasta, ora se aproxima do ponto de convergência entre o nível da linguagem e o temático, como autoconsciência poética. O último poema do último livro deixa em aberto as indagações sobre o amor, Deus, morte e despedida. Esses motivos ficam ecoando à procura de respostas ao caminho iniciado com o primeiro verso do poema I e o último verso do poema X, "Que este amor não me cegue nem me siga" e "O amor e sua fome".

O livro marca o encerramento do projeto de escrita de Hilda Hilst e com ele podemos refletir sobre o seu processo de expressão lírica. Nesse processo performático notamos um afastamento da veia puramente confessional. Assim, é possível pensar no eu lírico capaz de expressar-se tanto "em si" como "fora de si”, seus próprios sentimentos a respeito da vida e de suas mazelas, preconizadas pelo conflito existencial que percorre a sua obra.

A configuração discursiva de Hilst remete à noção de subjetividade, no plano da expressão. A esse respeito, é possível trazer o pensamento de Käte Hamburger (2013), que aponta o sujeito lírico considerado como sujeito-de-enunciação na noção de subjetividade. Para Hamburger, um enunciado, mesmo que de teor subjetivo, sempre vai se dirigir ao objeto. Isto quer dizer que, no caráter comunicativo da linguagem, os enunciados partem de um polo subjetivo para um polo objetivo. Contudo, o que faz um sujeito ser lírico não é a "elevação lírica", mas o contexto de enunciação da linguagem em que este discurso se manifesta (2013, pp. 168 e 169).

Os estudos sobre a subjetividade feitos por este teórico compõem uma linha possível de análise da poesia de Hilst, no que se refere à atuação do eu lírico. Para ele, os polos subjetivo e objetivo se juntam no enunciado para dar sentido a este. Em outras 
palavras, o que pretendemos dizer não é, de forma alguma, que a comunicação poética encerra-se em si. E sim que, na poesia de Hilst, a presença intensa de um "tu" expresso em seus versos comprova que no processo criativo de sua obra não há antinomias do eu e do outro, e sim uma cena que envolve ora o eu, ora o outro. A relação sujeito de enunciação e enunciado supõe interlocução discursiva por meio da anulação do próprio sujeito que se torna um, conforme se apresenta nesses versos do poema VII: "Perdi-me tanto em ti/ Que quando estou contigo não sou vista / E quando estás comigo veem aquela" (HILST, 2004, p.23).

Os procedimentos empregados por Hilda Hilst no livro Cantares estabelecem pontos de convergência e divergência entre as formas da lírica, e, do ponto de vista temático, entre elementos aparentemente antagônicos tais como vida e morte, amor e ódio, entre outros. Isso demonstra a dimensão poética proposta por Hilda Hilst como forma de despolarização de termos aparentemente opostos. O seu processo de criação encena a dicção do sujeito que, ao se desalojar de sua pura interioridade, destitui a maneira de ser da lírica tradicional não como segregação, mas como agregação de tons e estilos dos vários tempos. O “eu” destituído de sua soberania exprime o seu estado anímico ao lançar-se fora de si e perde o controle de sua interioridade, porque precisa de um interlocutor que se utilize das mais variadas máscaras. Esse movimento se configura em Hilst, assim como se faz regra na formação lírica da modernidade. Com isso, os tempos modernos e seus pressupostos geram conflitos existenciais, porque o homem sai da zona de conforto racional e se descentraliza. O eu lírico hilstiano, neste livro, parece também refletir sobre esses paradoxos: as verdades universais são abaladas e o sujeito lança-se para fora de si e se projeta para o mundo e para a linguagem, desencantados. É o que trataremos no capítulo seguinte. 


\section{CAPÍTULO II}




\section{DA LÍRICA DO DESEJO}

Para pensar o Outro, eu deliro ou versejo. Pensá-LO é gozo. Então não sabes? INCORPÓREO

É O DESEJO

(Hilda Hilst)

\subsection{Do desencantamento e do desejo}

Retomando o pensamento de Becker, em que o mal do mundo deriva da necessidade de negar a morte, nele internalizam-se formas de desencantamento do homem perante o mundo e as reflexões sobre sua consciência. Para esse autor, o homem sente necessidade de viver verdades vitais, como a de ser herói de sua história e "um dos conceitos-chave para compreender essa ânsia pelo heroísmo é a ideia de narcisismo" (2013, p.20). Todavia, o mesmo autor afirma que na era moderna, o heroico parece ser grande demais e, essa constatação transforma-se em experiência frustrada. O mundo da modernidade legou ao homem a crise do heroísmo e isso o leva a negar o que não pode mais dominar, levando-o a indagar sobre sua própria identidade.

Junte-se a esse pensamento a ideia de desencantamento, palavra ícone da modernidade, que promove reflexão sobre a condição do "estar no mundo" no presente. Muitas considerações têm sido feitas a respeito desse termo por teóricos, principalmente os da filosofia, sociologia e psicanálise, os quais discutem a questão sob o argumento de que com o advento da modernidade, desde o século XVII até o início da segunda metade do século XX, há o processo de desagregação ou deslocamento do homem do seu centro 
e, consequentemente, o seu afastamento das velhas identidades estáveis. A esse descentramento, em que o indivíduo se desliga do estado de referência unificada, assim como na condição de herói de sua história, atrela-se a chamada "crise de identidade". E a crise, produzida pelo processo de desencantamento de mundo, instalou, no homem, o desejo de busca constante que desencadeia o sentido da consciência estrutural de solidão humana.

Em estudo sobre o sentido do termo desencantamento do mundo em Max Weber, Pierucci, 2013, infere que o significado da palavra pode ser análogo aos termos “desenfeitiçamento”, “desdivinização”, “desmagificação” de mundo. Marx Weber, em seus escritos dos primeiros anos do século $\mathrm{XX}$, retoma o termo desencanto ou desencantamento de mundo como estado de perda da referência centralizadora das coisas, gerada pela substituição da figura de Deus em detrimento da industrialização e dos avanços científicos. Portanto, em sua opinião, rompe-se o pensamento de mundo antigo. A partir de então, depois do "destronamento" de Deus como figura onipotente, da qual emana todo o sentido das coisas, o homem começa a eterna busca de explicar sua existência pelo viés da racionalidade, porém nem sempre consegue explicá-la. O homem passa a viver à mercê de uma série de desejos materialistas, que consomem sua essência humana e o coloca em estado de conflito. O legado advindo do pensamento da modernidade, ao desarticular o homem do seu centro, instaurado pelas instâncias que governavam o mundo até o final da Idade Média, leva o homem a desconfiar de si e, em consequência disso, nasce nele o desejo de fixar essa nova identidade.

Essa nova configuração identitária humana interfere no modo como a arte é concebida, em se tratando de seus temas e motivos. Em Do desejo, (1992), de Hilda Hilst, veremos que o eu lírico se apropria do sujeito em falta, sujeito este que se projeta na busca 
de si, e essa projeção só poderá representar-se no Outro, cujo caminho de representação perpassa também pelo desejo de ser da arte. No poema X de Do desejo, vemos os versos:

$$
\mathrm{X}
$$

Pulsas como se fossem de carne as borboletas.

E o que vem a ser isso? perguntas.

Digo que assim há de começar o meu poema.

Então te queixas que nunca estou contigo

Que de improviso lanço versos ao ar

Ou falo de pinheiros escoceses, aqueles

Que apetecia a Talleyrand cuidar.

Ou ainda quando grito ou desfaleço

Adivinhas sorrisos, códigos, conluios

Dizes que os devo ter nos meus avessos.

Pois pode ser.

Para pensar o Outro, eu deliro ou versejo.

Pensá-LO é gozo. Então não sabes? INCORPÓREO

É O DESEJO.

(HILST, 2004, p. 26)

A imagem do movimento ritmado que indica o batimento de uma artéria na superfície sanguínea de um determinado corpo vivo, inicia o poema, no primeiro verso. O verbo "pulsas" e a palavra "carne" anunciam a que vem a lírica de Hilst: sempre feita na agitação das tensões movidas por intermitente busca. A imagem desse movimento remete também à preparação para o início de um voo, que se comporta mais como questionador do que definidor de algo. Esse voo pode configurar também o começo do poema. Diferente de outros poemas já analisados, no que se refere à relação interlocutiva, este inicia-se com interpelação do interlocutor: "Pulsas como se fossem de carne as borboletas. / E o que vem a ser isso? perguntas." Só a partir do terceiro verso é que aparece a voz do eu lírico: "Digo que...”. "Dizes que...”, no décimo verso; “... eu deliro ou versejo.” No penúltimo verso.

O quinto, oitavo e décimo versos da primeira estrofe são fundamentais para refletir sobre a atuação do eu lírico hilstiano, neste poema, no que se refere à forma e ao conteúdo: 
"Que de improviso lanço versos ao ar" / "Ou ainda quando grito ou desfaleço" / "Dizes que os devo ter nos meus avessos.”. Quanto à forma, apenas os três versos são decassílabos, o que já é um dado para pensar sobre a preocupação com as formas fixas do verso, entre os demais de métrica livre. Por esse motivo, a palavra "improviso", no quinto verso tem seu sentido distorcido, já que sugere não ser de improviso que se faz versos, caso contrário, não haveria essa disposição com a métrica de dez sílabas.

A voz lírica de Hilst mostra-se aqui como voz que se lança no processo de constituição poética, marcado pela busca de si no outro. Nos versos: "Dizes que os devo ter nos meus avessos." e "Para pensar o Outro eu deliro ou versejo", é possível ver que o teor da palavra desejo, como incorpóreo, delimita o status do trânsito da busca humana, no outro, pelo avesso de si. Vemos que o eu lírico envolve-se num jogo de perguntas e respostas com seu interlocutor, representado pelos verbos "pulsas", "perguntas", "queixas", seguidos de "adivinhas", “dizes" e [...] Então não "sabes"? A tentativa de diálogo com o interlocutor simula um eu aparentemente inquieto, mas o poema não apresenta a intenção de responder a essas inquietações, pois importa mesmo é o processo de pensar o outro, pois, "Pensá-LO é gozo" [...]. O gozo, para o eu lírico, sugere o pensar na realização do desejo de representar-se e de deixar a marca de sua lírica.

Essas considerações iniciais encaminham para discussões que pretendemos fazer sobre a poesia de Hilda Hilst, no presente capítulo, a partir do livro Do desejo. Veremos que várias formas de interlocução serão estabelecidas por um eu movido pela procura, pleno desejos, sem, contudo, esperar respostas. Para isso, retomamos a noção do sujeito "fora de si" mencionada no capítulo anterior. Há, de modo mais agudo, neste livro, a desestabilização do sujeito, gerada por um suposto enfraquecimento da individualidade em estado de contemplação de si, advindo do pensamento do sujeito da modernidade. 
Para tanto, é interessante voltarmos ao pensamento de Michel Collot, também mencionado no primeiro capítulo, quando diz:

Fazendo a experiência de seu pertencimento ao outro - ao tempo, ao mundo ou à linguagem -, o sujeito lírico cessa de pertencer a si. Longe de ser o sujeito soberano da palavra, ele se encontra sujeito a ela e a tudo o que o inspira. Há uma passividade fundamental na posição lírica, que pode ser similar a uma submissão. Sem poder mais se sustentar em um fundamento transcendente ou transcendental, não seria esse arrebatamento em direção ao outro uma pura e simples alienação? Sem poder mais cantar Deus ou o Ser ideal através das palavras e das maravilhas tanto da criação quanto da criatura, o sujeito que se precipita para fora de si se encontra lançado em um mundo e em uma linguagem desencantados. (COLLOT, p.165).

As proposições de Collot sobre a desestabilização do sujeito de seu centro produzem reflexões acerca daquilo que se designa subjetividade e o posicionamento do sujeito lírico. Ao retomar Collot, queremos enfatizar um eu lírico, que o autor denomina sujeito, por representar a instância da lírica da modernidade, cuja experiência poética sai de si e passa a ser objeto da palavra. Esse sujeito, ao sair de si, transporta um tipo de lírica que pode se lançar "em um mundo e uma linguagem desencantados", no qual é possível ver um tipo diferente de subjetividade. Contudo, uma subjetividade diferente daquela pregada por Hegel, já que para Hegel, ela alcança em si a consciência de sujeito (eu), cuja lírica não se encontra mais na exterioridade, mas sim na apreensão de si e da exterioridade como consciência individualizante do sujeito (eu). ${ }^{41}$

Em Do desejo, não há o estado de contemplação diante do mundo como na estética romântica, tampouco o da submissão à linguagem. Em vez disso, o eu lírico detém a palavra e coloca o Outro sob seu domínio como forma de enfatizar que sua lírica é regida pelo desejo de representar-se e este desejo se mostra como uma experiência desorganizadora do ser, no sentido de colocá-lo, sempre, no trânsito da busca humana. A

\footnotetext{
${ }^{41}$ Convém lembrar que o pensamento de Hegel tem como pano de fundo a subjetividade romântica, nascida da inadequação entre o homem e o mundo, porque o homem romântico está voltado para si. E essa é a pedra de toque do romantismo: um tipo de subjetividade voltada somente para si mesma, que apreende o mundo naquilo que ele tem de sensível, e no movimento para dentro de si cria o ideal de beleza.
} 
busca está também atrelada à existência e à dimensão profunda do inexplicável humano e, por isso, serve de elo entre o ser e o mundo.

A ideia de mundo desencantado permite olhar para a poesia de Hilst em um lugar no qual é possível explicar as coisas pelo viés do desejo. A questão da representação na alteridade não se parece exclusivamente com a poética de Hegel nem com as concepções Collot, mas é possível aproximar-se das conceituações dos dois, já que notamos ser possível pinçar de cada uma das proposições desses dois teóricos o que convém e o que se adequa ao entendimento da lírica hilstiana.

Assim, a linguagem poética se faz da subjetividade que se transfigura em experiência de linguagem e pode servir de contínua travessia entre o ato de dizer e o não dito, por meio de uma voz lírica que sai de si para encontrar-se no Outro e volta para si no momento em que se realiza. Dessa espécie de operação temos, em Hilst, uma subjetividade singular, feita do desejo em ser travessia também para outros lugares e tempos. Obviamente, para se chegar a isto é necessário pensar sobre o discurso em trânsito entre polos opostos, que se materializa sempre na representação de um contexto, de um tempo e de um espaço, expressos em sua poética. Num estudo sobre a poesia da autora, Nelly Novaes Coelho conclui que:

\footnotetext{
Como toda grande poesia (a que é tecida por um $\mathrm{eu}$ interior centrado em si e ali buscando a porta de acesso ao Enigma da Vida), a de Hilda Hilst expressa em seu suceder as metamorfoses de nosso tempo. Ou melhor, algumas interrogações mais radicais do pensamento contemporâneo: uma de natureza física (psíquico-erótica) (...) outra, de natureza metafísica (filosófico-religiosa) (...). (COELHO, 1999, p.67).
}

As interrogações latentes da poesia contemporânea refletem o mundo descentrado, no limiar entre o profano e o sagrado, que sublimam a experiência poética. E na forma de ser da lírica de Hilst, pela materialização do desejo em forma de linguagem, este torna-se sujeito principal de toda a sua poética. Dizendo de outro modo, a palavra 
desejo é vista como substantivo mesmo, colocado no centro da intenção do poema. Isso se evidencia, no plano dos temas e motivos, como um tipo de desejo apresentado não como corpo material, como no poema X, citado acima, porque é "incorpóreo": "PensáLO é gozo. Então não sabes? INCORPOREO / É O DESEJO”. A grafia em maiúsculas não é aleatória, mas apresenta a forma como se constitui a lírica hilstiana no que tange a um tipo de desejo, que, neste caso, incorpora-se tanto para pensar a materialidade da palavra como o Outro, que representa também o eu. E a representação do eu-no-Outro não difere muito de questões que envolvem um sujeito "fora de si-no-outro", já tratadas em Cantares e que se refazem em Do Desejo.

\subsection{Da reunião Do Desejo}

O volume Do Desejo, lançado a primeira vez pela Editora Pontes, Campinas, (1992) e cujo título foi dado pela própria autora, é uma junção de sete livros publicados entre 1986 e 1992, após a publicação da chamada "trilogia obscena"42, em prosa, e o quarto livro, em poesia satírica, também chamado de "obsceno", Bufólicas. A publicação de Bufólicas no mesmo ano de publicação de Do desejo é um dado no mínimo instigante para o crítico, porque ambos os livros, embora distintos do ponto de vista temático, levam à reflexão sobre uma marca constante na obra hilstiana: o fato de haver todo tipo de tensão possível, quer seja temática, estrutural ou de elaboração de linguagem. Tanto nas obras ditas "obscenas ou pornográficas", quanto naquelas ditas "sérias ou lúcidas", Hilst não

\footnotetext{
42 Os livros de ficção O caderno rosa de Lori Lamby (1990); Contos d'scárnio. Textos grotescos (1990) e Cartas de um sedutor (1991) fazem parte da chamada "trilogia obscena". Com a publicação de Bufólicas (1992), poesia, fechou-se a "tetralogia obscena". Essas obras incomodaram muito o público crítico e leitor. Segundo a própria Hilda, em entrevista concedida para a TV Cultura em 1990, (http://www.youtube.com/watch?v=5yeFhO4G2OQ). O Caderno Rosa de Lori Lamby, segundo a autora, foi um ato de agressão para os editores, para o mercado editorial, porque nunca a tinham lido com seriedade antes disso. Acrescenta também que é um livro de humor e que há uma tristeza muito profunda no mundo, por isso o riso é uma saída para uma saúde mental geral.
} 
perde o tino da densidade reflexiva sobre questões que incomodam o ser e que se refletem em sua linguagem poética. E ela mantém essa atmosfera densa em todos os seus livros, mesmo quando resolveu escrever "bandalheiras" (termo utilizado pela própria autora e também pela personagem Lory de O caderno rosa de Lory Lamby, 1990), para se referir ao projeto de publicação das obras "obscenas".

Os livros que compõem o volume Do desejo não seguem uma ordem cronológica de publicação, mas sim, modos diferentes de tratar questões que envolvem o desejo, ora traduzido em desejo corpóreo, ora em desejo como busca metafísica do ser, trazendo para si uma forma dupla de estabelecer seu conceito. A ordem cronológica de publicação é invertida; seu último livro, Sobre tua grande face, foi publicado em 1986 e o seu primeiro, Do desejo, em 1992. Parece que não é a organização cronológica que importa para os volumes e reuniões em Hilst. O mesmo também acontece em Cantares, conforme já foi afirmado. O que importa são as questões recorrentes em todos os livros do volume. A esse respeito: "Do desejo traz consigo possibilidades semânticas interessantes de cruzamentos entre eles, que o tornam verdadeiramente um livro novo, único.” (PÉCORA, 2004 p. 8$)^{43}$. A questão do desejo sempre aparece como um dado desarticulador da poesia em todos os livros da reunião, mas em situações distintas.

Não é nossa intenção trabalhar minuciosamente cada livro da reunião. Para o presente capítulo fixaremos maior atenção nos dois primeiros, Do desejo e Da noite, por perceber neles, traços da palavra lírica "desejo" com tons marcantes para a compreensão do livro como um todo. Para situar a organização do volume em relação ao ponto de ligação entre seus livros, mencionaremos, de forma breve, apenas algumas especificidades de alguns deles.

\footnotetext{
${ }^{43}$ Em "Nota do organizador" do volume Do desejo, (2004).
} 
Amavisse, (1989), antes de integrar Do desejo foi também o nome de um volume que reuniu mais dois livros: Via espessa e Via vazia (ambos publicados no mesmo ano de Amavisse). Foi dedicado à memória de Ernest Becker e de Vladimir Jankelevitch ${ }^{44}$, autor da epígrafe: “... ter um dia amado (amavisse)”. O livro constitui um dos aspectos mais caros e que também se manifesta nos demais livros que compõem Do desejo: a relação estabelecida entre o sujeito desejante e o objeto desejado, que é, muitas vezes, o próprio ato de desejar. No poema X de Amavisse:

\author{
Um incêndio de angústias e sons \\ Sobre os intentos. E no corpo da tarde \\ Se fez uma ferida. A mulher emergiu \\ Descompassada no de dentro da outra: \\ Uma mulher de mim nos incêndios do Nada. \\ Tinha o rosto de uns rios: quebradiço \\ E terroso. O peito carregado de ametistas \\ Uma mulher me viu no roxo das ciladas: \\ Esculpindo de novo teu rosto no vazio.
}

(HILST, 2004, p. 51)

Os primeiros três versos do poema instauram uma atmosfera de dor e sofrimento: "Um incêndio de angústias e sons", verso que perfaz uma imagem do processo do sofrer, pelo tom pleonástico, que amplia o sentido de angústia pelas palavras "incêndio" e "sons". O sentido de desejo vem por meio da palavra "intentos" no segundo verso, preparando o movimento para fazer surgir, no poema, uma outra persona: "Uma mulher nos incêndios do Nada." A imagem dessa mulher, que emerge de dentro, apresenta-se como mediadora entre o eu lírico e seu interlocutor, ou seja, o eu lírico saindo de si mesmo, mediado pela dor de desejar ser a outra. A imagem da outra vai sendo construída por meio do desejo

\footnotetext{
44 Vladimir Jankelevitch foi um filósofo e musicólogo de ascendência russa, nasceu na França. Foi influenciado pelo pensamento do filósofo Henri Bergson. Uma de suas ideias mais enfáticas é que a moral é o problema central na reflexão filosófica.

http://www1.folha.uol.com.br/fsp/mais/fs0609200914.htm Acesso em 07/05/2014.
} 
apresentado no poema como algo que arde, no "incêndio de angústias". Desta forma, a dupla atuação do sujeito feito por si e pelo outro, que emergiu do processo doloroso de desejar, torna possível o surgimento também do desejo que se manifesta no ato de realizar novamente a busca do outro e no outro. Assim, o que importa é o ato de desejar, porque a realização do desejo se funda no vazio, fora do conceito de satisfação plena: "Uma mulher me viu no roxo das ciladas: / Esculpindo de novo teu rosto no vazio."

Em outro aspecto, Sobre a tua grande face, último livro da reunião, é também dedicado à memória de Ernest Becker e "A Guilherme Dicke ${ }^{45}$ por identificação no exercício da procura. Neste último livro, os poemas trazem a marca do desejo manifestado na ânsia de conhecer e na tentativa de explicar a existência de Deus. O desejo é também o do eu lírico, que busca a si próprio, como nos versos: "Vem apenas de mim, ó Cara Escura / este desejo de te tocar o espírito (...)" (HILST, 2004, p.114). E a busca se transforma em dor, que o eu lírico não consegue nomear:

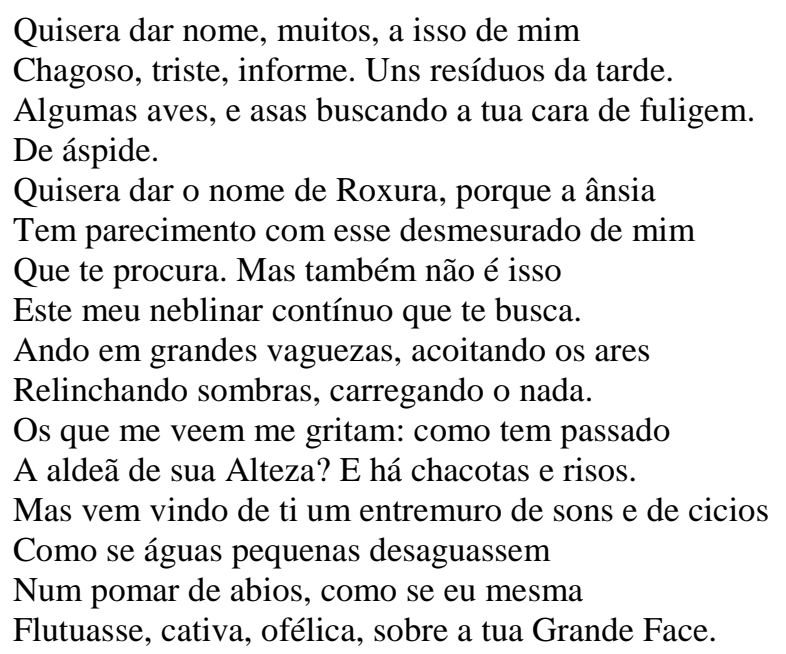

(HILST, 2004 p.115)

\footnotetext{
45 Guilherme Dicke foi um poeta mato-grossense, escreveu uma vasta obra, mas foi pouco conhecido. Também trabalha em seus poemas o tema da morte. Morreu em 2008. Foi apontado por Hilst como um dos "gigantes" da literatura nacional.
} 
Nos versos do poema há também a expressão de um eu lírico que procura, incessantemente, algo inatingível, o "isso de mim", uma ânsia que incomoda em toda a poesia de Hilst e se limita com o próprio objeto de desejo: dar nome ao movimento do desejar o inominável, que projeta sentidos na nomeação de Deus e na interlocução com ele. O sentido de desejar intensifica-se de "ânsia" para "Roxura", destacado com inicial maiúscula para chamar a atenção ao seu sentido e seu nível de importância em relação ao sentido de "ânsia". Roxura refere-se a um desejo louco, uma excitação sem medidas: “Quisera dar o nome de Roxura, porque a ânsia/ Tem parecimento com esse desmesurado de mim/ Que te procura. Mas também não é isso /Este meu neblinar contínuo que te busca." A imagem "neblinar contínuo que te busca" conota o movimento de ir e vir, ou seja, a busca torrencial, sem medidas e, ao mesmo, tempo branda e constante.

A ideia de intensa procura permeia o livro. No primeiro poema de Sobre tua grande face, os seguintes versos: "Por isso me sentiria aliviado. E de ti, Sem Nome /Não desejo alívio. Apenas estreitez e fardo.” (HILST, 2004, p. 111), remetem ao trabalho de uma suposta nomeação do que não tem nome, ou melhor, daquilo que não se pode ou não se consegue nomear. Uma busca inominável, voltada para indagações sobre a incompletude do ser, como nos versos, "[...] isso de mim/ Chagoso, triste, informe. Uns resíduos da tarde.”

As questões relacionadas à procura intensificam-se nos dois primeiros livros da reunião Do desejo, do ponto de vista do eu lírico sobre a concepção da palavra desejo. No nível dos motivos e temas o primeiro livro, de título homônimo ao da reunião, apresenta uma noção de desejo voltada para a dicotomia tensiva entre o corpo e o espírito. A dedicatória, “À memória de Apolônio de Almeida Prado Hilst, meu pai.”, infere a intenção de reverenciar seu pai ${ }^{46}$, que teve uma história de vida, movida por um desejo

\footnotetext{
${ }^{46}$ Apolônio de Almeida Prado Hilst foi o pai de Hilda Hilst, morreu paranoico e esquizofrênico. Foi escritor não reconhecido pelo público de sua época. Hilda declara em entrevistas que seu pai foi responsável pela
} 
enorme de ser conhecido pela escrita; isto, entretanto não aconteceu. Os versos da epígrafe “Quem és? Perguntei ao desejo. / Respondeu: lava. Depois pó. Depois nada”, de autoria da poeta, remetem aos aspectos que integram o desejo corpóreo, aquele que se desfaz ao nada. A partir deste pensamento, o livro mostra uma relação entre amante e amado que parece se realizar na ordem da tensão entre o eu e o outro, metaforizando a relação carnal para incorporar-se na palavra poética. Vejamos o primeiro poema:

I

\author{
Porque há desejo em mim, é tudo cintilâncias. \\ Antes, o cotidiano era um pensar alturas \\ Buscando Aquele Outro decantado \\ Surdo à minha humana ladradura. \\ Visgo e suor, pois nunca se faziam. \\ Hoje, de carne e osso, laborioso, lascivo \\ Tomas-me o corpo. E que descanso me dás \\ Depois das lidas. Sonhei penhascos \\ Quando havia o jardim aqui do lado. \\ Pensei subidas onde não havia rastros. \\ Extasiada, fodo contigo \\ Ao invés de ganir diante do Nada.
}

(HILST, 2004, p. 17)

No primeiro verso, o eu lírico aponta para o desejo como condição da existência do ser. Chama a atenção pela forma, composta por doze sílabas poéticas, alexandrino, cujas cesuras se dão na sexta e décima-segunda sílabas. Esse tipo de métrica, utilizado pelos clássicos, impõe certa exaltação de sentimentos: o verso incide sobre a ideia de manifestar a intenção em mostrar o desejo que vem de um "em si" do eu lírico, e se manifesta ao ser iniciado com a conjunção explicativa "porque". O sentido lírico da palavra "desejo" se apresenta como peça motora que move todo o ser vivo em seu estado

escolha no campo da literatura: "Eu fiz minha obra por causa do meu pai. Eu queria agradar meu pai. Queria que um dia ele dissesse que eu era alguém. É isso". (Entrevista "Das sombras", CLB n ${ }^{\circ} 8$, Instituto Moreira Sales: 1999, p. 26.). 
físico e metafísico: a materialização do desejo como carência, impotência, enquanto não se realiza.

O sexto verso do poema também apresenta doze silabas poéticas e propõe sentidos, não só na forma, como nos motivos expressos pelo eu lírico: O "Antes" no segundo verso, e "Hoje", no sexto, mostram o desejo como algo inatingível, e por isso mesmo, desejável: “Antes, o cotidiano era pensar alturas”. Depois a satisfação, mesmo que momentânea da realização do desejo: "Hoje, de carne e osso, laborioso, lascivo.” A busca da realização do desejo ideal cede lugar ao desejo real, de forma a tornar o ideal corpóreo, de carne e osso. Por isso, a condição animalizada do homem se interpõe e ganha força no verso "Surdo à minha humana ladradura." e "Extasiada, fodo contigo / Ao invés de ganir diante do Nada". (destaques meus). Assim, podemos vislumbrar um tipo de desejo corpóreo, debatendo-se com a incorporeidade; dizendo de outra forma, trata-se do desejo que só se realiza no nível da tensão entre o material e o imaterial.

Ademais, a relação "amado e amante" sugerida pelo poema mostra ainda, pelo primeiro verso, não só a linguagem do desejo, mas o desejo da linguagem: "Porque há desejo em mim, é tudo cintilância”, no qual o eu lírico se apresenta pela exteriorização do desejo que move a capacidade de ser. A linguagem é vista como movimento de subidas e descidas no trabalho de buscar uma forma "decantada" de se manifestar. O mesmo movimento que acontece com um eu movido pelo desejo e pela ânsia de desejar. Os versos “Tomas-me o corpo. E que descanso me dás / Depois das lidas. Sonhei penhascos/ Quando havia o jardim aqui do lado. / Pensei subidas onde não havia rastros." apontam para esse movimento tenso e frenético do eu em busca do outro, a saída da interioridade para exteriorizar-se e manifestar-se no outro, por meio do desejo: "Buscando Aquele Outro decantado". Notamos uma configuração de lírica em que a materialização do desejo só é feita por meio do movimento do eu em busca da falta. A representação no outro se 
dá quando este, o desejo, é corporificado e passa a ser representado pela carência e impotência enquanto não se realiza.

Essas considerações sobre o desejo estabelecem, na poesia hilstiana, a relação com o ser desencantado da modernidade, ou seja, a figura do homem movido por desejos e por perdas. Para essa discussão sobre o desejo, importa trazer Marilena Chauí, que em "Laços do Desejo", diz ser possível a mística do desejo como "uma noção privilegiada para captarmos o advento do mundo desencantado, particularmente quando acompanhamos sua mutação, passando de conceito metafísico a conceito psicológico.” (1990, p.22). O desejo, tido como entidade cósmica e teológica, deixou de ser o motor do universo e passou a ser subjetivo da alma e da paixão humanas e, por isso, os estudos da psicologia e da psicanálise passaram a geri-lo. Infere a autora: "O desencantamento do mundo tem como pressuposto essa decisiva mutação do desejo que, de misteriosa potência cósmico-teológica, transmuta-se em simples potência da alma, cujo enigma cabe à razão decifrar inteiramente”. (1990, p.22). Esse pensamento afeta a forma de ver o mundo e, consequentemente, a arte. Vê-se aqui um tipo de subjetividade lírica, que não se fecha em si, mas desaloja-se, regida pelo desejo de ser.

Evidentemente, essas reflexões conceituais acerca da identidade poética não são nenhuma novidade. Como já afirmado, as experiências da modernidade do século XIX trouxeram o desencantamento do mundo, o que provocou a mitigação do tempo no qual o homem já não é, perde a consciência de ser, situação que o coloca em crise consigo mesmo e à mercê do desejo. Muito antes, desde o "Ser ou não ser" de Hamlet, a identidade do homem entra em conflito. Santos (1990, p. 211) afirma que, com essa máxima hamletiana, foi rompida "a experiência religiosa da vida e do mundo, e com isso rompeuse também a integridade do homem - agora, o que o faz sofrer é a sua mente, não as suas paixões, os seus desejos, os seus atos". Se o homem está em conflito de identidade, 
logicamente ele não terá mais desejos próprios e passará a desejar o desejo do outro, pois, segundo Santos, “o que o faz sofrer é a sua desconfiança, é a incapacidade de decidir e de agir" (1990, p. 211). Assim, verifica-se e vivifica-se, conforme Santos, com o "Ser ou não ser" de Shakespeare, que a afirmação de reflexão vinda do interior do indivíduo; assim como "Deus é, ou não é" de Pascal, é uma visão exteriorizada. Podemos dizer que, com Hamlet, ocorre, de fato o início do mal da modernidade: a consciência da solidão torna o eu soberano e, ao mesmo tempo, perdido e individualizado.

Aqui temos um modelo de sujeito conflituoso, a exemplo do eu poético de Hilda Hilst, na obra Do desejo, movido pela ausência e pela falta. Não há como compatibilizar os polos do Eu/Outro. No mundo não organizado, que é o mundo regido pela multivalência de concepções, não cabe o desejo numa visão univalente, mas sim numa visão tensiva, isto é, o desejo só se realiza no duplo desejo, no Outro. Esse modo de conceber o desejo e de vivê-lo engendra sofrimento.

Com Hamlet foi rompida a experiência religiosa da vida e do mundo, as certezas se abalaram e rompeu-se também a integridade do homem: "como posso desejar se desconfio de mim, se nem sei se sou?" Ou: "Como posso desejar se estou o tempo todo a duvidar?" (SANTOS, 1990, p.212), o “ser ou não ser" bloqueou o desejo do ponto de vista cósmico e religioso, num mundo em que Deus não mais é, e como o homem pode desejar ser se desconfia de si próprio? A resposta a esta questão seria desejar o desejo do Outro. A propósito disto, a condição humana passa a ser regida pelo desejo de representarse.

A relação entre desejar e ser manifesta-se como uma constante na poesia de Hilst, porque causa uma situação de instabilidade discursiva e constitui conceitos para a sua lírica. Esse procedimento não ocorre só em Do desejo. Retomamos alguns versos de 
Cantares de perda e predileção, em que essa questão também se configura na dicotomia do sublime e do não sublime:

XLIX

\author{
Se comedimento \\ Mornidão, prudência \\ Me dourassem a carne \\ E o coração \\ Tu me dirias rouco \\ Que a bem do Desejo \\ Desfez-se o Paraíso \\ E inventou-se a Paixão. \\ Bem por isso preserva \\ Quem te sabe inteiro \\ E cala teu instante \\ De um ciúme que repete \\ Que devo ser repouso \\ E contenção.
}

(HILST, 2004, p. 86).

Estes versos trazem à tona as reflexões sobre o desejo do sublime, prudente e comedido em contraposição ao desejo/ paixão ${ }^{47}$. Os dois conceitos de desejo se debatem e se configuram em algo que não é nem um nem outro tipo de desejo, mas a inteireza deles: "Bem por isso preserva / Quem te sabe inteiro / E cala teu instante / De um ciúme que repete / Que devo ser repouso / E contenção".

\title{
2.3. Do desejo
}

Assim, em Do desejo também temos o desejo de representação poética das mazelas humanas e seus conflitos, que configura como possibilidade do sujeito lírico hilstiano neste livro, e traduz uma realidade externada no ser da poesia. O livro é composto por dez poemas que sintetizam o sentido de desejo para a poeta; os poemas são

\footnotetext{
${ }^{47}$ Os termos, "desejo sublime" e "desejo paixão" são sinônimos do desejo apetite, o que está intimamente ligado ao corpo e à urgência; e do desejo aspiração, que se refere ao incorpóreo, à incompletude da alma. Esses conceitos serão retomados e desenvolvidos nas páginas seguintes deste capítulo.
} 
interligados pela mesma linha de força que traduz um estado de espírito conflituoso. $\mathrm{O}$ primeiro verso do poema I "Porque há desejo em mim, é tudo cintilância" e o primeiro do poema $\mathrm{X}$ "Pulsas como se fossem carnes de borboletas" demonstram todo o movimento sugerido pela imagem "carnes de borboletas", pulsantes, e "cintilância", como se o desejo fosse marcado no livro por uma liberação de faíscas de um corpo incandescente. Esse movimento percorre os poemas do livro, na tentativa de compor a expressão do desejo, que se reflete de várias formas.

O poema VII sugere o espelhamento de um sujeito inadaptado, refeito na união de contrários, de autoconsciência e de corpo físico. A ideia de espelhamento tem sentido duplo, pois o sujeito lírico prefere a "dor e o fastio", e, ao mesmo tempo, a deslumbrante beleza que se curva ao desejo físico e é, para a poeta, sinônimo de vida. Parece haver uma dor voltada para um tipo de desejo incorpóreo:

\title{
VII
}

\author{
Lembra-te que há um querer doloroso \\ E de fastio a que chamam de amor. \\ E outro de tulipas e de espelhos \\ Licencioso, indigno, a que chamam desejo. \\ Não caminhar um descaminho, um arrastar-se \\ Em direção aos ventos, aos açoites \\ E um único extraordinário turbilhão. \\ Porque me queres sempre nos espelhos \\ Naquele descaminhar, no pó dos impossíveis \\ Se só me quero viva nas tuas veias?
}

(HILST, 2004, p.23)

Há imagens utilizadas neste poema para referir-se ao desejo: "tulipas" e "espelhos". A recorrência à imagem da tulipa, flor de várias cores, uma planta que se sobressai entre as outras e chama a atenção para si pela altura de seu talo e a beleza de sua flor ${ }^{48}$. Já a palavra espelho, que aparece no plural, projeta não apenas uma imagem,

\footnotetext{
${ }^{48}$ É recorrente a menção à "tulipa" na poesia de Hilst. Como no poema I de Cantares do sem nome e de partidas, analisado no primeiro capítulo desta tese.
} 
mas várias e, no conjunto, pode distorcer o objeto e refratá-lo em um ou infinitos objetos. Essa visão caleidoscópica provoca combinações de sentido em que incide a lírica hisltiana, no que se refere ao desejo. A expressão de um querer corpóreo, incorpóreo, cuja voz, ávida dessa ânsia espiritual e desse desejo erótico, arde de paixão e desejo, como no verso: "E um único extraordinário turbilhão."

Não há reminiscências ao amor sensível e transcendental. No poema, este tipo de amor é regido pelo "querer" que se limita com o sentido de aspirar a algo. É um querer "doloroso e de fastio" e se reporta a um tipo de subjetividade deslocalizante do sentido de sensível para o de inteligível. O desejo metaforizado em "tulipas" e "espelhos" tem valor absoluto no poema, porque se sobrepõe ao amor, aquele que é descaminho e move a interioridade do ser. Este sentido de amor/querer, na poesia de Hilst, insiste em fazer sobressair o sentido do desejo carnal e o jogo entre os dois tipos de querer, o da carne e o do espírito. Esse procedimento configura o teor paradoxal de seu discurso porque, ao mesmo tempo em que o ser parece estar ligado ao ato de desejo, como aspiração, ele também não se satisfaz com este tipo de desejo.

Num estudo sobre Do desejo de Hilda Hilst, Elaine Cintra também se reporta à questão do desejo como uma constante na obra da poeta, no sentido de colocar a questão na ordem da subjetividade, que legitima a sua poética. Segundo Cintra, "Falar em desejo, a partir da modernidade, é naturalmente nos remeter à discussão de uma configuração da subjetividade, ou de um sujeito em falta que configura múltiplas projeções em busca de si”. (2009, p. 48). Nesta perspectiva, a subjetividade lírica posta na obra de Hilda Hilst remete a uma reflexão sobre o ser balizado no mundo em "fratura", no sentido de perda do centro e de desapossamento de si, movido pelo ato de desejar, que coloca em jogo a maneira de ver o mundo e conota um discurso feito por paradoxos entre um "querer", que se vincula no corpo e outro, no espírito. É o caso dos primeiros versos do poema VII: 
"Lembra-te que há um querer doloroso / E de fastio a que chamam de amor. / E outro de tulipas e de espelhos / Licencioso, indigno, a que chamam desejo."

A tensão existente entre os "quereres" remete não a um eu lírico contemplativo e introspectivo, como o da estética romântica, e sim, a um eu conflituoso, que busca encontrar-se fora de si, no sentido da "disposição anímica" de que fala Staiger (1975), na qual o sentimento não vem de dentro, da "alma", mas volta-se para as coisas e os objetos que se deseja cantar por meio do processo de recordação. Para o eu lírico, recordar "deve ser o termo para a falta de distância entre sujeito e objeto, para o um-no-outro." (1975, p.50).

Retomando o pensamento de Chauí, em Laços do desejo, "o desencantamento do mundo sofreu pequenas interrupções no correr dos últimos séculos, com a emergência periódica dos irracionalismos: o romantismo exacerbado, o niilismo, o nazi-fascismo e, no momento, o pós-modernismo". (1990, p.22). Com isso, o desejo deixa de ser uma prerrogativa mítica para ser uma potência da alma. Ainda segundo Chauí, o desejo que move o homem contemporâneo pode ser um caminho para entendermos o mundo desencantado que foge da metafísica para o inconsciente da alma. Esta noção de mundo desarticula o homem e seu discurso passa a ser o da reflexão sobre as tensões que envolvem as percepções de corpo e de espírito. Essas duas formas de desejo vêm desde Platão, o desejo "aspiração" que remete à alma e o desejo "apetite" ligado mais ao corpo, como necessidade imediata de realização. Ao discutir sobre esses dois tipos de desejo, Pessanha pondera que o desejo "aspiração" é o nostálgico anseio de retorno à incorporeidade pura, apontando para "alhures," já o desejo “apetite persegue vorazmente na sofreguidão do corpóreo, o aqui e o agora.” (1990, p. 91). O autor ainda defende que: permite-nos discernir o verdadeiro sentido do idealismo platônico, enquanto preeminência do ideal em relação ao real imediato, do modelo em relação à cópia, do paradigma em relação a sua provisória e precária imitação concreta, da significação plena em relação aos signos inevitavelmente parciais e incompletos de sentido, do 
condicionante em relação ao condicionado, do absoluto em relação ao hipotético, da justa medida - justeza e justiça, na matemática, na ética, na política - em relação ao valor aproximado. Ou: da alma em relação ao corpo." (1990, p.95)

Os pares que Platão apresenta podem ser tomados como ideias para a compreensão da dicotomia que se materializa em Hilst. E essa dicotomia envolve o outro também como o interlocutor de seus versos. O desejo é a aspiração de preenchimento daquilo que falta. É um processo de carência que tumultua o pensamento e potencializa o objeto desejado na presença da imagem desse objeto. O homem, como ser desejante, não sabe muito bem como lidar com o desejo, porque ele desloca a essência humana. É algo que se realiza no nível da tensão entre o eu e o objeto de desejo.

Há variadas visões sobre a definição da palavra desejo. Na psicanálise, o desejo é "uma moção psíquica que procura restabelecer a situação da primeira satisfação, expectativa consciente ou inconsciente de possuir (um objeto) ou alcançar (determinada situação que supra uma aspiração do corpo e do espírito); exibição, exigência". (Dicionário Houaiss da Língua Portuguesa). Etimologicamente, deriva do latim desiderium, de desiderare, esperar por, desejar, ter expectativa, cujo sentido original talvez tenha sido "esperar pelo que as estrelas trarão", de desidere, "dos astros" ${ }^{49}$ Numa leitura desse vocábulo, Chauí (1990, p.23), retoma desiderium com o sentido de perda; para ela, o desejo chama-se, então, "carência, vazio que tende para fora de si em busca de preenchimento, aquilo que os gregos chamavam de hormê." Ou seja, deriva da expressão latina Reliquia desiderantur que significa, falta o restante. A autora infere que o sentido da palavra desejo passa por vários teóricos. Espinosa define desiderium como desejo ou apetite de possuir algo que foi visto em situação de deleite e que ficou na lembrança. Hobbes, para quem amor e desejo, segundo a autora, significam a mesma coisa, mesmo

\footnotetext{
${ }^{49}$ Disponível em: http://origemdapalavra.com.br. Acesso em 20/004/2015.
} 
que desejo seja ausência e amor seja presença. Para Freud, o desejo também é visto como carência ou falta que culmina em desejar ser objeto de desejo para o outro.

O estudo que Chauí desenvolve sobre o desejo retém maiores forças na crítica do filósofo Espinosa ${ }^{50}$. Para este filósofo, é a razão quem cria o desejo, mas sem ter pleno poder sobre ele. A razão não tem a capacidade de imunizar o ser humano de ser vítima do desejo, porque este se submete constantemente às forças externas. A razão, segundo Chauí, não nos corta do mundo nem nos separa de nosso corpo. "Como ação intelectual, é simplesmente uma maneira melhor e mais feliz de estar no mundo, ter um corpo e ser uma alma.” (1990, p.63). Para Espinosa:

"Ninguém pode desejar ser feliz, agir bem e viver bem que não deseje, ao mesmo tempo, ser, agir e viver, isto é, existir em ato. O que é evidente por si e pela definição de desejo, pois o desejo deve viver feliz, isto é, de ser, agir e viver é a própria essência do homem pelo qual cada um se esforça para conservar seu ser". (apud Chaú, 1990, p.63):

As concepções discutidas por Chauí apontam para reflexões a respeito do que seria a linha do pensamento moderno de humanidade, a qual fez surgir o desencantamento movido pelo desejo, como "apetite" e "aspiração", responsável pela desorganização do mundo. Essas reflexões são perceptíveis quando pensamos nos procedimentos da lírica de Hilda Hilst, no livro Do desejo, no sentido de trazer à tona, a partir de seu discurso, considerações que se relacionam com a postura do ser e da arte do presente. Se o desejo se faz como princípio vital para qualquer circunstância da experiência humana, para Hilst, este legado também se configura como motivo primordial da obra poética. $\mathrm{O}$ desejo de ser poesia, que se realiza ao fazer-se e ao ser "visto" ou "lido". Um discurso imbricado de potências contrárias que não se polarizam, mas que colocam tanto o poeta, quanto o discurso, em situação de trânsito. Para a poeta, o desejo significa condição da existência humana, sempre prenhe de quereres, pois estes sustentam, como uma faca de dois gumes,

\footnotetext{
${ }^{50}$ Espinosa foi um dos grandes racionalistas do século XVII, da chamada filosofia moderna.
} 
a vida e a feitura poética. Em entrevista concedia à equipe dos Cadernos de Literatura Brasileira - IMS - ao ser questionada sobre o fato de a poética do desejo ter sido sempre buscada por ela, Hilda Hilst responde: "Daquele suposto desejo que um dia eu vi e senti em algum lugar. Eu vi Deus em algum lugar. É isso o que eu quero dizer." ${ }^{1}$ (CLB, 1999, p. 37). Desta forma, na lírica de Hilst, a linha de força perseguida é a de encontrar no outro, em ausência, a intensificação do sofrimento pela falta. Veremos isso no poema a seguir:

\title{
VIII
}

\begin{abstract}
Se te ausentas há paredes em mim.
Friez de ruas duras

E um desvanecimento trêmulo de avencas.

Então me amas? te pões a perguntar.

E eu repito que há paredes, friez

Há molimentos, e nem por isso há chama.

DESEJO é um Todo lustroso de carícias

Uma boca sem forma, um Caracol de Fogo.

DESEJO é uma palavra com a vivez do sangue

E outra com a ferocidade de Um só Amante.

DESEJO é Outro. Voragem que me habita.
\end{abstract}

(HILST, 2004, p.24).

O poema é construído pela palavra desejo, grafada por três vezes em maiúsculas, aparece desta forma para enfatizar definições: "DESEJO é...” Há marcas do desejo sensual e sensorial, que se manifestam como experiência discursiva. A expressão do desejo chama a atenção para o que o eu lírico quer exprimir: concepções de desejo como marcas de um sujeito que vive das tensões entre o corpóreo e o incorpóreo. Essa ideia é articulada pelos paradoxos "ruas duras" e "desvanecimentos trêmulos de avencas" e expressa um tipo de sentimento do eu lírico, na ordem da tensão entre o que é dor e solidão, provocado pela prisão resultante da ausência do suposto amado. É como se o sujeito ficasse preso, pela ausência do objeto, ao amado, às duas faces do desejo: a do

\footnotetext{
${ }^{51}$ Entrevista concedida à equipe dos Cadernos de Literatura Brasileira- IMS - que trata sobre várias questões, entre elas, o pensamento da autora em relação a sua obra e a recepção do público. Hilda se coloca como um ser inadaptado, mas com a certeza do "dever cumprido", ou seja, de ter falado tudo o que tinha que falar ao realizar seu trabalho de escrita.
} 
sensível e a do inteligível, neste caso, o desejo "apetite" e o desejo "aspiração", e dessa relação não conseguisse se desligar. A ausência é algo que separa, como no verso: "Se tu ausentas há paredes em mim”. A falta provoca também solidão e aprisionamento pela imagem "parede" reafirmada pelo verso: "E eu repito que há paredes, friez".

Os sétimo, nono e décimo-primeiro versos iniciam com a palavra desejo em maiúsculas, acompanhada do verbo "é" como elemento definidor. O eu lírico constrói o sentido de desejo por meio da repetição inicial de "DESEJO é”. As palavras e expressões utilizadas para defini-lo também são grafadas com iniciais maiúsculas: "Todo”, "Caracol de Fogo", "Um só Amante", "Outro”, e constroem uma gradação que intensifica o que quer expressar como desejo, o fato de este só se realizar no Outro, como no último verso: "DESEJO é Outro. Voragem que me habita." Temos, neste caso, a performance do eu lírico fora-de-si-no outro. Esse procedimento discursivo evidencia um eu lírico que se apropria de imagens como "Caracol de fogo", como metáfora da desordem a qual provoca o desejo ardente no ser desejante.

A materialização da palavra desejo, concebida como apetite do corpo que desemboca no querer da alma, perpassa os versos deste primeiro livro da reunião Do desejo. Neste livro, o desejo corpóreo parece sobrepor-se ao desejo incorpóreo, mas não o anula, cria tensão e produz uma espécie de discurso mediado pelo intervalo entre um e outro tipo de desejo. Entre a incompletude do desejo "aspiração" e a urgência do desejo “apetite” está o ser e o discurso de Hilda Hilst, conjugados pela potência tensiva de seus versos: "DESEJO é um Todo lustroso de carícias” e também: “DESEJO é Outro, voragem que me habita”. (HILST, 2004, p.24). 


\subsection{Da noite}

O segundo livro da reunião de Do desejo é composto também por dez poemas, como o primeiro. A lírica exposta nestes poemas transpõe os limites do sentido de desejo como "apetite" ou "aspiração". Este novo sentido se configura numa voz que quer cantar o desejo de ser poesia, por meio da representação imaterial. Com o objetivo de contribuir para um melhor entendimento do livro é preciso retomar alguns sentidos do conceito de desejo sobre os quais o segundo livro se debruça. Sobre ele e sobre suas origens, de acordo com o pensamento filosófico, há muitos estudos. Antes do conceito ser nominado por várias terminologias é interessante mencionar como ele surgiu. Num sentido bem amplo, desde a criação do homem e do mundo, primeiro surge o espírito, depois a consciência de corpo e espírito, só depois a Dialética e com ela desejo. Bornheim, em estudo sobre o desejo em Hegel e Marx, infere que, para Hegel, a consciência separa o homem da vida universal, o que faz surgir o desejo como experiência de desejos particulares. A separação da vida universal proposta pela consciência acontece em dois níveis: “como separação da vida universal e como particularização do desejo numa sequência de desejos separados. O homem deseja e consome aquilo que deseja. (...) O desejo de se afirmar como desejo através do objeto desejado.” (BORNHEIM, 1990, p. 148). Ao consumir o objeto desejado, o ser decreta a sua morte. Portanto, o que o ser deseja não é o objeto, mas o ato de desejar que o torna vivo. Assim, continua o autor, "de tanto desejar, instaura-se uma espécie de vício, que exige que o desejo seja desejo de si mesmo; o objeto, então não passa de um meio para que o desejo possa ser." (BORNHEIM, 1990, p. 149). Para o idealismo de Hegel a respeito do desejo, este é avassalador, porque impulsiona o homem para ações que consequentemente deixarão vestígios de ruína e destruição. Assim que o desejo se manifestar nele mesmo, os resultados serão de insatisfação para o sujeito. Já 
que o desejo em si não se satisfaz, o sujeito buscará realizar-se na alteridade, e nem sempre terá uma resposta satisfatória no processo desejante do objeto.

Para além de uma questão meramente temática sobre o desejo, em Da noite, o segundo livro da reunião, há marcas comuns que são as de refletir sobre o desejo aparentemente do ponto de vista material, porém em constante reflexão sobre a essência humana, um paradoxo entre consciência e corpo físico, que acaba se fragmentando diante do silêncio e da solidão. E sendo assim, a concepção de desejo se configura como imaterial, porque os prazeres da carne são passageiros e inomináveis, mas nem por isso menos dolorosos, no poema VI temos:

\author{
O que é a carne? O que é este Isso? \\ Que recobre o osso \\ Este novelo liso e convulso \\ Esta desordem de prazer e atrito \\ Este caos de dor sobre o pastoso \\ A carne. Não sei este Isso. \\ O que é o osso? Este viço luzente \\ Desejoso de envoltório e terra. \\ Luzidio rosto \\ Ossos. Carne. Dois Issos sem nome.
}

(HILST, H. 2004, p. 34)

De forma mais sensorial, os versos trazem possibilidades estéticas significativas que se juntam e realçam o aspecto físico do desejo de forma paradoxal. Ao mesmo tempo em que marca o perecível da carne: "Esta desordem de prazer e atrito / Este caos de dor sobre o pastoso", e do osso: "Desejoso de envoltório e terra", mostra também a incerteza e a impossibilidade de saber o que significam e como podem ser nomeados os prazeres da carne.

Há, no poema, uma retórica para referir-se ao conceito de desejo, ou à impossibilidade de conceituá-lo como desejo corpóreo. A começar pelas palavras que indicam movimento: "convulso", "desordem", "atrito", "caos", em combinação com 
"liso", "prazer", "dor". No quinto verso da primeira estrofe "Este caos de dor sobre o pastoso" configura uma espécie de "confusão" na intenção de tentar racionalizar uma compreensão do que seja o desejo. Os pronomes demonstrativos "este" e "esta", que aparecem, na primeira estrofe, seguidamente, no início de três versos, estabelecem uma forma de atuação do eu lírico que aproxima de si não o sentir do desejo, mas a ânsia de exteriorizá-lo. É como se estivesse nas entranhas a impossibilidade de definição e de desestabilização causada pelo desejo. O "Isso" "52, que lembra o "Isso de mim" no poema III de Cantares, apresenta-se como sujeito da busca de nomeação, em uma poética que arde no desejo de desejar.

Em Da noite parece haver, de forma mais acentuada, essa preocupação do sentido de desejo relacionado à incapacidade de realizar-se plenamente em si; o ser passa a desejar algo inalcançável e isto instaura um grande conflito causador de frustração. Se o que torna vivo o ser é o processo que envolve o ato de desejar e não o próprio objeto desejado, a poesia de Hilst, em Da noite, propõe uma forma de refletir sobre a própria poesia como processo de criação ligado a transitoriedade das paixões e coloca em questão o tipo de subjetividade lírica de seus versos. Vejamos o poema II:

Que canto há de cantar o que perdura?

A sombra, o sonho, o labirinto, o caos

A vertigem de ser, a asa, o grito.

Que mitos, meu amor, entre os lençóis:

O que tu pensas gozo é tão finito

E o que pensas amor é muito mais.

Como cobrir-te de pássaros e plumas

E ao mesmo tempo te dizer adeus

Porque imperfeito és carne e perecível

E o que eu desejo é luz e imaterial.

Que canto há de cantar o indefinível?

$\mathrm{O}$ toque sem tocar, o olhar sem ver

A alma, amor, entrelaçada dos indescritíveis.

Como te amar, sem nunca merecer?

(HILST, 2004, p. 30)

\footnotetext{
${ }^{52}$ Como no poema III de Cantares do sem nome e de partidas, analisado nas páginas 56-58.
} 
Há um dado interessante para a compreensão da lírica hilstiana neste poema. Curiosamente, a forma é parecida com um soneto. O poema contém catorze versos em cuja métrica predominam os decassílabos. Apenas o terceiro, o sétimo e o décimo-terceiro apresentam métrica diferenciada. Contudo, mesmo não apresentando a versificação rígida, o poema possui um certo ritmo, produzido pela combinação dos versos interrogativos e pelas rimas, sobretudo nos últimos versos. O soneto ${ }^{53}$ é uma forma discursiva fixa e por isso racionalizada do ponto de vista estrutural, e é empregada de maneira consciente pela poeta. É possível aproximar também o poema de Hilst, à forma de soneto, pela divisão estrutural, a saber: os quatro primeiros versos propõem questões sobre o tema desejo: "Que canto há de cantar o que perdura?”; os próximos quatro versos acrescentam argumentos ao que foi questionado, colocando várias possibilidades de respostas. Os versos:” Porque imperfeito és carne e perecível / E o que eu desejo é luz imaterial. / Que canto há de cantar o indefinível?" assim agrupados, como se fosse um terceto, apresentam uma unidade de sentido que encaminham para o "desfecho" apresentado no último verso: “Como te amar sem nunca merecer?”, que concentra em si a ideia principal sobre as indagações propostas no poema.

A coincidência formal do poema com o soneto reforça, ainda, mesmo de maneira desrealizada, a relação com essa forma poemática, pois a semelhança só se dá, sobretudo, pelo número de versos, pela presença dos decassílabos, e pela divisão temática dos versos, e apresenta o diálogo que a poeta busca com algumas formas da tradição. Todavia, esse diálogo é utilizado por Hilst como um procedimento discursivo no trato com o objeto que quer cantar: o desejo. Neste caso, o desejo em todas as suas dimensões, mas sobrepõe-se,

\footnotetext{
${ }^{53}$ Para Salvatore D’Onófrio, a “estrutura rígida do soneto, que obriga o poeta a condensar em poucos versos a expressão de um sentimento, explica talvez a preferência que tem por essa forma poemática os poetas lúcidos, aqueles que entendem que a poesia é a arte das palavras conscientemente organizadas para produzir sentidos surpreendentes". (1994, p. 96).
} 
aqui, o desejo imaterial, aquele que não cabe no canto da poeta, porque é de difícil definição, e por isso precisa ser pensado e racionalizado.

Nesse sentido, sua voz transita pelas formas da tradição, e não perde a posição de poeta "lúcida e consciente" do seu trabalho poético, realizando um discurso interlocutivo com essas formas, mas não criticamente. Hilst, neste caso, impõe sua voz de maneira diferente da dos modernos: ela não se curva à palavra, sua poesia não se enquadra no conceito rigoroso de poesia como "arte da palavra" pregada por alguns modernos. Em pesquisa realizada sobre o livro de contos "Fluxo-floema", Reguera (2013) corrobora que o texto de Hilst "atua nos alicerces da tradição dinamizando-a e reescrevendo por meio de conjunto de procedimentos discursivos e de temas matizados pela sua trajetória como autora e sua posição e visão no mercado literário". (2013, p. 67). A estudiosa refere-se à "instância narrativa" hilstiana, mas isso serve também como ponto de reflexão para a sua poesia, no sentido de que sua proposta de escrita não cabe em nenhuma fórmula, porque ela cria uma própria forma de dizer: “Que canto há de cantar o que perdura?”. Este verso é o cerne de expressão do desejo de que a linguagem de sua poesia se perpetue, assim como o ato de desejar, que alimenta o homem da modernidade, colocando-se como condição do seu existir.

Confluindo com a impossibilidade de definir claramente o desejo, vemos também a impossibilidade de cantá-lo. Se desejar é perdurar sempre em estado de tensão, retomando, no poema II, as palavras "sombra, sonho, labirinto, caos, asa, grito" ${ }^{4}$, todas definidas pelos artigos que as precedem, estão postas na ordem do inalcançável e criam sentidos obscuros. Pode-se dizer que os sentidos dessas palavras estão na esfera do desejo como "aspiração", pois se ligam mais à alma do que ao corpo. E a ideia do impalpável apresenta-se pela segunda estrofe do poema, composta por apenas um verso: "E o que eu

\footnotetext{
${ }^{54}$ Dos versos: "Que canto há de cantar o que perdura? / A sombra, o sonho, o labirinto, o caos /A vertigem de ser a asa e o grito".
} 
desejo é luz e imaterial.” Essa estrofe chama a atenção para si e impõe-se tanto como forma, quanto como conteúdo. É uma estrofe que parece querer afirmar ou responder ao primeiro verso do poema; no entanto, o primeiro verso da estrofe seguinte desrealiza a mesma afirmação, e retoma o questionamento inicial: “Que canto há de cantar o indefinível?"

Por essa razão, há uma espécie de movimento de resistência do eu lírico ao descentramento, porque volta para si; entretanto, é uma voz provocativa que quer fisgar o leitor e impor-se diante dele. Há em Hilst um processo de distanciamento e ao mesmo tempo de aproximação do movimento, na construção das imagens poéticas, do eu para o outro; do eu para a ausência do outro e do eu para dentro dele mesmo. No poema acima citado, esse movimento se faz, por exemplo, por meio da tensão entre o finito e o infinito: “O que pensas gozo é tão finito / E o que pensas amor é muito mais. / Como cobrir-te de pássaros e plumas / E ao mesmo tempo te dizer adeus / Porque imperfeito és carne e perecível / E o que eu desejo é luz imaterial.”

O posicionamento do eu lírico que comporta a segunda estrofe do poema encaminha para além do entendimento apenas temático da palavra desejo, tem-se a tentativa de compreensão da sua forma poética, que se debate consigo mesma, cuja corporeidade se ancora numa voz lírica que se impõe, ao mesmo tempo em que simula uma incapacidade de descrever seus próprios pensamentos. É como se o canto do desejo não coubesse no poema de forma racionalizada: "Que canto há de cantar o indefinível? e "A alma, amor, entrelaçada dos indescritíveis."

Uma questão delineada pelo percurso da voz poética de Hilst é aquela que culmina no sentido de desejo relacionado ao de paixão. Essa que habita o ser e provoca uma situação de instabilidade em que corpo e espírito, retomando o pensamento de Espinosa, não se sobrepõem um ao outro. Com isso, o "corpo" do poema também se faz de maneira 
instável. Como fio condutor há um sujeito desejante e uma poética em estado de desejo de ser, porque a voz do poeta é a voz do desejo. No poema III do livro, flagramos estes versos: "Vem dos vales a voz. Do poço" e "Se faz paixão, serpente, e nos habita." Vemos uma voz que vem da interioridade do eu lírico e explicita-se na forma paradoxal de seus versos, pelas palavras "vales", "poço".

A voz poética, em Da noite, prende-se também à questão do desejo como busca vital para o ser. Como se a realização do desejo material se mostrasse de forma inconsciente, numa conjunção de elementos que formam aquilo que torna o discurso ambivalente. No primeiro livro, Do desejo, a palavra desejo aparece explícita em quase todos os poemas. Já em Da noite, ela permeia a linguagem de forma mais velada, mas tendo ainda, a mesma força semântica e é feita por meio dos paradoxos:

\title{
VIII
}

\author{
Costuro o infinito sobre o peito \\ E no entanto sou água fugidia e amarga \\ Eu sou crível e antiga como aquilo que vês \\ Pedras, frontões no Todo inamovível. \\ Terrena, me adivinho montanha algumas vezes. \\ Recente, inumana, inexprimível. \\ Costuro o infinito sobre o peito \\ Como aqueles que amam.
}

(HILST, 2004, p. 36)

Neste poema, há uma tensão entre o pensar e o sentir, remetendo a uma linha de força que se mistura e se debate com ela mesma. Ao mesmo tempo em que o eu se afirma como inabalável, ele se perde nas incertezas e no inexprimível. Isso se percebe na relação entre os dois primeiros versos em que "Costuro..." sugere o absoluto, mas na condição de aprisionamento, para logo em seguida, com "E no entanto...", supor o relativo e o impalpável. Esse jogo que percorre o poema todo sugere a imagem de um abismo feito de "pedra", desembocando no conflito existencial que o aprisiona e impossibilita a realização plena de liberdade. 
O poema promove uma preocupação com o ato de construir: "Costuro o infinito sobre o peito". O verbo costurar no sentido de desejar o infinito, algo impossível de se realizar, indica uma retórica da representação poética do desejo empenhada por Hilst. A imagem constituída por este verso sugere uma carga de significâncias e permite visualizar um sujeito que junta o exterior, "infinito", ao interior de si, "peito", no exercício de “costurar", limitando-se ao movimento do fazer da poesia. Entretanto, o eu lírico aqui se vê diante da impossibilidade de afirmar sua própria identidade, pois ela lhe escapa entre os dedos: "E no entanto sou água fugidia e amarga".

O universo poético se estabelece como uma massa líquida, "água fugidia”, que se dissolve ao ser tocada, produzindo uma sensação de se estar pisando em um terreno sobre o qual as relações entre presente e passado parecem tênues. Isso constrói uma reflexão paradoxal por meio dos adjetivos "antiga" e "recente", “crível” e "inexprimível", lembrando o diálogo com o passado e a aceitação do presente inútil que não se projeta no futuro, mas busca a afirmação do momento e não do eterno. O eu lírico de Hilst se afirma num tempo gerido pelo desejo, aquele que é sempre o agora, porque é o desejo que arde pela falta e a necessidade de desejar que torna acesa a chama da vida e da poesia. Pela dor do arder em desejo, o abismo feito de pedra se abre entre o eu e o ato de desejar. Os signos "pedra", "terrena”, "montanha" exprimem a dureza da racionalidade inteligível com feições para o sensível: "Costuro o infinito sobre o peito / como aqueles que amam”.

É possível ver em Da noite elementos que legitimam o status do sujeito lírico da modernidade, inspirado pelo desencanto de mundo busca afirmar-se regido pelo desejo de representar-se. O modo de ver o mundo pela engrenagem do desejo imbrica, na obra de Hilst, uma visão estilhaçada do ser. A fragmentação do homem e do mundo, advinda do pensamento da modernidade, interfere e perturba o seu discurso ao ponto de colocar 
em conflito a totalidade das coisas. Desta forma, o eterno se confunde com o transitório. A visão destotalizante de mundo desemboca num forte anseio que gera angústia.

O poema em questão configura um sujeito que, movido pela ânsia de desejar, funde-se com o mundo. Isso provoca um desvio não só da linguagem, mas um desvio do sujeito de si mesmo, um distanciamento do criador enquanto ser que se cria com o outro eu para ser seu interlocutor. O desejo passa a ser o da condição dupla, que se faz pelo discurso em constante travessia.

O exercício poético de Hilst em Do desejo, visto pelo espelhamento entre os dois primeiros livros, torna possível perceber mais claramente a performance da lírica, movida ora pelo desejo imaterial, ora pelo amor/paixão, cujos sentidos se cruzam em algum ponto para que se estabeleça a interlocução com o outro. Neste caso, o outro que muitas vezes é o próprio eu fora de si no Outro, em seu avesso. O eu que passa a ser não mais a sua individualidade, mas a sua alteridade. Por conseguinte, a relação interlocutiva, neste livro, apresenta uma dimensão que ultrapassa a relação do eu com outro revestido de tu, ou mesmo, interlocução com as formas poemáticas e com o status do pensamento puramente da modernidade. A maior e mais importante aqui é a interlocução com o Desejo, porque este, não se apresenta apenas como objeto, mas como sujeito na constituição dos poemas.

Se em Do desejo, o eu se realiza pelo desejo no outro, a ausência deste eu se manifesta com êxtase na figura do outro ausente. Este pensamento faz com que se retome o pensamento de Collot quando diz que "fazendo a experiência de seu pertencimento ao outro - ao tempo, ao mundo ou à linguagem -, o sujeito lírico cessa de pertencer a si.”. (p.165). Isto pode tornar o sujeito lírico submisso à ausência do interlocutor, e, com isso, assumir uma posição de passividade, ou não. É o que observaremos no próximo capítulo. 
CAPÍTULO III 


\title{
3. DA INTERLOCUÇÃO LÍRICA COMO AUSÊNCIA
}

\author{
$[\ldots]$ \\ A ideia, Túlio, essa ilha escondida \\ É límpida, encantada, se faz prata \\ Vive através de ti. Por isso brilha. \\ (HILST, 2003, p. 54) $)^{55}$
}

Toda poesia compreende um movimento relacional, no qual sempre haverá um eu que se dirige a um interlocutor, seja ele o leitor, ou um outro, ficcionalizado pelo eu poético. Os versos acima citados performatizam um tipo de procedimento caro à constituição lírica de Hilst, no que se refere a uma voz que canta e deseja ser ouvida, e a um interlocutor criado de modo eloquente, em presença/ausência. Nele se constitui o centro do processo de criação de Hilst, como no verso da epígrafe: "Vive através de ti. Por isso brilha." A lírica empreende certo tipo de comunicação poética por meio do interlocutor, imbricada numa enunciação pressuposta por um enunciado em que o eu e o tu se constituem reciprocamente.

Essas questões, já tratadas nos capítulos anteriores, serão o fio condutor de análise dos poemas contidos em "Ode descontínua e remota para flauta e oboé. De Ariana para Dionísio", que se encontra no livro Júbilo, memória, noviciado da paixão, publicado em 1974. Veremos que, de certa forma, a voz lírica hilstiana, através de um eu fictício, Ariana, fala a um outro também fictício, Dionísio, e, neste caso, diz para esse outro o que diria para si mesmo. Assim, a constituição da obra hilstiana transita por questões da existência humana e da própria existência poética, apresentando um eu lírico, cuja voz, ao falar de si também encena outras vozes.

\footnotetext{
${ }^{55}$ Última estrofe do poema III que abre a sessão "Moderato Cantabile", de Júbilo, memória, noviciado da paixão, 2003.
} 
T. S. Eliot no ensaio As três vozes da poesia (1972) afirma que há três vozes na poesia moderna: a voz do poeta que fala de si para si mesmo, a que se dirige a um auditório e a que incorpora uma personagem dramática e dialoga com outros seres ficcionais. $\mathrm{Na}$ primeira voz, o eu lírico volta para dentro de si e apenas fala de si, e para si, sem se importar em ser ouvido. O próprio teórico problematiza a questão: um poema, mesmo escrito para um único destinatário, se isso é possível, pode também ser dirigido a um ou mais interlocutores. Os poemas de primeira voz, segundo o autor, são aqueles considerados não dramáticos, ou seja, são os que falam com a própria voz, "como esta soa quando se lê para si mesmo, constitui disso a prova, pois é o próprio autor falando. O problema da comunicação, daquilo que o leitor extrairá do verso, não é o mais importante..." (ELIOT, 1972, p. 134). A primeira voz de que fala Eliot não pressupõe um público porque não se reveste de um personagem dramático para falar de si, e por isso, não tem o propósito de comunicação. Isso virá naturalmente, porque a comunicação é uma função intrínseca à poesia, mesmo quando fala para si ou não quer comunicar nada em particular.

Na segunda voz descrita pelo autor do ensaio, o poeta fala de si e se dirige para um auditório; logo, pressupõe a presença de um tipo de interlocutor com o qual possa se fazer ouvir. É chamada de voz "quase dramática", porque incorpora um personagem num monólogo dramático. Na terceira voz o poeta também se transforma em personagem e a partir dele fala para um público personificado em outro personagem, um público com o qual tenta criar um elo interlocutivo. É uma voz que não fala por si, mas pela voz de um personagem que se dirige a outro ser ficcional. Desse modo, Eliot denomina essa terceira voz de dramática, por conter os elementos de uma peça de teatro.

As três maneiras didáticas de classificação das vozes poéticas, feitas por Eliot, não se fecham em si, não são vistas separadamente. Dessa forma, o processo de criação da 
voz poética sempre utilizará, conforme afirma o crítico, a junção e o fluxo entre as três vozes. No caso da poesia de Hilst, a presença de um público encerra sempre uma forma de diálogo com um interlocutor, seja ele um leitor, um personagem ou até as formas tradicionais de poesia.

É perceptível, em Ode descontínua e remota para flauta e oboé. De Ariana para Dionísio, o fluxo dessas vozes, que se constitui como forma e se conforma em elemento de tensão entre poeta e público. Alguns tipos de interlocução serão possíveis nesta parte do livro, já pela escolha, no título, da palavra "ode". A construção do título "Ode descontínua e remota..." tem uma carga de significação que alimenta o processo de diálogo harmônico, de continuidade, e desarmônico, de ruptura com o passado remoto, pela seleção dos temas e motivos presentes nos seus versos. A seção ${ }^{56}$ “Ode descontínua e remota para flauta e oboé. De Ariana para Dionísio" composta por 10 partes/poemas, configura-se como um único poema; basta ver no título a palavra "ode" no singular. É importante reiterarmos que a origem da forma "ode" vem do grego oidê, semelhante à palavra hino. Refere-se a um poema lírico destinado ao canto.

Ode era um poema caracterizado pela voz do cantor que servia de um instrumento de corda (lira ou harpa) para ao acompanhamento musical. Originariamente era um canto individual que expressava sentimentos pessoais, especialmente o amor. [...]. Atualmente, a ode libertou-se de todo constrangimento formal, aceitando, inclusive o verso-livrismo, o que leva a distinguir a ode de outras formas poemáticas. (D’ONÓFRIO, 1995, p. 67-8). ${ }^{57}$

Normalmente, as odes também adquiriam a forma coral e eram criadas para exaltar, em tom solene, algum acontecimento ou alguma personalidade, com versos em

\footnotetext{
${ }^{56}$ Será assim designada cada parte do livro Júbilo, memória, noviciado da paixão.

${ }^{57} \mathrm{~A}$ forma ode, quando se refere a um canto individual denomina-se de sáfica, da qual Horácio, um dos maiores poetas latinos, é representante. Quando trata de assuntos elevados e solenes, denomina-se heroica ou pindárica. (D’ONOFRIO, 1995, p. 69). Neste caso, a Ode de Hilst reflete um canto individual, com a intenção de louvar e cantar para Dionísio.
} 
tom alegre. Contudo, os adjetivos dados à Ode ${ }^{58}$ hilstiana, "descontínua e remota", não são nada eufóricos; o adjetivo "descontínua” nega também o canto alegre e entusiástico, próprio das formas das odes; "remota" alude à consciência do tempo, uma visitação às formas, guiada por uma memória "remota", mas foge à pura e simples imitação dessas formas, pois não adere a elas, e sim, mantém com elas um diálogo "nervoso" de aproximação e afastamento, que se desmancha na estrutura do poema. Em vez de instrumentos de corda, (lira ou harpa), a Ode hilstiana prefere os de sopro (flauta e oboé). É importante ressaltar, estes são instrumentos que emitem sons agudos, ao mesmo tempo suaves e doces. A flauta, por exemplo, é um instrumento musical primitivo usado para acompanhar os rituais místicos e religiosos.

Dadas essas maneiras de interlocução com as formas, outro ponto curioso para análise é que a Ode foi escrita separadamente, em $1969^{59}$, no intervalo entre a dramaturgia e a inauguração da prosa da autora, para depois ser agrupada ao volume de 1974. Isso leva ao entendimento da preferência de Hilda Hilst pelo gênero poesia. Segundo Alcir Pécora, responsável pela reedição deste volume no ano de 2003, Hilda Hilst reinaugura o gênero poesia, pois foi o primeiro depois da publicação de sua obra dramática e, portanto, “posterior ao jorro dramático e ao início já maduro dos livros de prosa". ${ }^{60}$ Para Pécora, talvez este seja o motivo de haver elementos de narratividade incorporados aos poemas.

Há aspectos recorrentes no livro: a preocupação em perpetuar-se como poeta e como poesia, feita em tom de lamúria, como se fosse possível impedir a passagem do momento presente. Interessante que essa preocupação parece estar ligada, na obra, à

\footnotetext{
${ }^{58}$ Será utilizada esta nomenclatura, com inicial maiúscula, para o título Ode descontínua e remota para flauta e oboé: De Ariana para Dionísio.

${ }^{59}$ Nesse ano a autora começa a escrever sua prosa com o conto "O Unicórnio" que foi publicado como parte de Fluxo-floema, e 1970. DESTRI, Luisa e DINIZ, Cristiano. Cronologia. In: Pécora, Alcir. (org) Por que ler Hilda Hilst. São Paulo: Globo, 2010, p.59.

${ }^{60}$ Nota do organizador do livro Júbilo, Memória e Noviciado da Paixão, 2003, p. 12.
} 
relação amado/amante, e que o ponto de intersecção de todos esses elementos é a voz sempre se dirigindo a um distante interlocutor masculino. Desta forma, podemos adiantar que, no livro citado, é possível perceber mais claramente um eu lírico, cuja palavra de ordem, como veremos na leitura desta seção, é a "espera” do amado que está ausente, e essa palavra de ordem encena-se como motivo desencadeador da voz poética, porque conota uma intensidade de tons da poesia amorosa, não como derramamento sentimental, mas como construção sutil de ausência.

Essas questões inerentes à relação interlocutiva entre amado e amante estão inscritas ao longo da reunião Júbilo, memória, noviciado da paixão. Numa breve apresentação, o livro é composto por sete seções: "Dez chamamentos a um amigo", "O poeta inventa viagem, retorno e sofre saudade", "Moderato cantabile", "Ode descontínua e remota para flauta e oboé. De Ariana para Dionísio", "Prelúdios intensos para os desmemoriados do amor", “Áreas pequenas. Para bandolins" e "Poemas aos homens do nosso tempo". No decorrer de cada seção vemos que há possibilidades de interlocução do eu do poema com o outro ficcional, sendo eles Dionísio, Túlio, o amado, o amigo, Pastor, ou os "homens do nosso tempo".

Na primeira seção do livro "Dez chamamentos para um amigo"61, os dez poemas que a compõem desvelam a ideia de súplica e de evocação. O título desta seção lembra

\footnotetext{
${ }^{61}$ Os poemas de Hilst nesta seção, de algum modo, lembram o procedimento estrutural e temático das cantigas, mas não é intenção desta pesquisa enfatizar detalhadamente tal linha de leitura. A título de referência, as cantigas de amigo constituem a variedade mais importante e original da produção lírica da Idade Média, estas composições se enquadram na poesia trovadoresca. $\mathrm{O}$ homem se refere à sua amada como sendo uma figura idealizada, distante. O poeta fica submisso às ordens de sua senhora, dama da corte e a realização desse amor está no plano do impossível, porque a amada está distante. "Um tipo peculiar de cantigas de amigo é o das paralelísticas, que aliam uma simplicidade de motivos e recursos semânticos ao elaborado arranjo da sua expressão, através de um esquema de repetitividade que enriquece o sentido pelo tom de litania e sugestão encantatória, muitas vezes magoada, perplexa ou interrogativa, que cria. Típicas da poesia galaico-portuguesa, encontram-se também nas cantigas de amor e noutras variedades poéticas medievais, persistindo até muito tarde na literatura medieval. O rei D. Dinis é um dos seus mais famosos cultores". Disponível em: http://cvc.instituto-camoes.pt/literatura/cantigasamigo.htm. Acesso em $\underline{12 / 12 / 15}$.
} 
as cantigas de amigo trovadorescas em alguns aspectos, mas se distanciam em outros.

Temos uma voz que busca interlocução com o amado; contudo, essa busca parece ser pretexto para falar de si, como alguém que implora e evoca um interlocutor, mas quer chamar a atenção para si. Trazemos este poema que abre o livro:

\author{
Se te pareço noturna e imperfeita \\ Olha-me de novo. Porque esta noite \\ Olhei-me a mim, como se tu me olhasses. \\ E era como se a água \\ Desejasse \\ Escapar de sua casa que é o rio \\ E deslizando apenas, nem tocar a margem. \\ Te olhei. E há tanto tempo \\ Entendo que sou terra. Há tanto tempo \\ Espero \\ Que o teu corpo de água mais fraterno \\ Se estenda sobre o meu. Pastor e nauta \\ Olha-me de novo. Com menos altivez. \\ E mais atento.
}

(HILST, 2003, p. 17).

A relação entre eu e tu ${ }^{62}$ é estabelecida pelo processo de reversibilidade, porque ambos se fundem e se confundem reciprocamente. Nos três primeiros versos do poema, o eu e o tu não são vistos como opostos, pois a voz do eu lírico evoca o seu interlocutor para que ele o observe atentamente. A ideia de espelhamento é feita pelo procedimento de se ver no outro e de ser olhado pelo outro. $\mathrm{O}$ segundo verso, iniciado pelo imperativo "Olha-me” e pela súplica: "de novo" remete a um chamamento que envolve um movimento de repetição e de retorno à memória do interlocutor, como se ele já tivesse sido olhado, mas não atentamente. Há a visão de interioridade do eu lírico em relação à ótica do interlocutor, pela imagem do rio que flui sem escapar de seu leito, sem tocar a

\footnotetext{
${ }^{62}$ Referimo-nos ao pensamento de Emile Benveniste, sobre a concepção de subjetividade em Problemas da linguística geral I, 1988. Para o autor, principalmente na comunicação oral, o eu e o tu estabelecem uma relação contraditória. $\mathrm{O}$ eu dirige-se, no ato da comunicação, a alguém a quem chama de tu, que acaba tornando-se o eu na reciprocidade do ato da comunicação.
} 
margem, sem transbordar. Essa ideia de contenção impermeabiliza o derramamento, e esse obstáculo impede a junção da terra e da água. Por isso, o eu lírico pede para ser olhado novamente, porque deseja ardentemente essa junção.

No terceiro verso: “Olhei-me a mim, como se tu me olhasses" há uma combinação sonora semelhante a "molhasse", remetendo à fluidez da água, "do corpo de água” em junção com a terra "entendo que sou terra". Isso pode sugerir a transformação em barro, possível de ser modelado e, a partir dele, a obtenção de formas. A imagem do barro, que surge da junção de terra e água, remete a uma recorrência na poesia de Hilst, que é a interlocução do eu lírico com a construção estrutural do poema. Uma espécie de metalinguagem guiada pelo processo do nascimento a partir do barro. E esse nascimento só será possível pelo olhar, que revela a intimidade do eu lírico com o oficio de escrever. Por isso, os versos: "olhei-me a mim como se tu me olhasses" e "Te olhei. E há tanto tempo", reforça a ideia de espelhamento, do eu-no-outro, também entendido como o espelhar de sentimentos e de emoções do eu no poema.

A interlocução com o "Pastor e nauta" estabelece a possibilidade de diálogo da voz que pretende legitimar-se por meio deste como voz não solitária, mas encena e simula uma maneira de submissão ao seu interlocutor. O desejo, que só é percebido por meio do último verso da primeira estrofe "Desejasse", e pelo terceiro verso da terceira estrofe, "Espero", suplica a constante reincidência do olhar do interlocutor sobre o eu lírico. Um "olhar de novo" e "mais atento".

Assim, esta seção do livro prepara o leitor para o que vem a ser a voz lírica de Hilst em sua obra, sobretudo na Ode. Essa voz é apresentada como uma espécie de fusão das três vozes das quais fala Eliot, porque ela se comunica consigo mesma e, ao mesmo tempo, dirige-se a um ser fictício a quem nomeia Dionísio, configurado como ouvinte, isto é, um suposto público. Contudo, esta voz nunca esquece de si. Há uma voz que fala 
da solidão em tom lamurioso, pela falta de um amado distante, e outra que se reinventa e se preocupa com o devir de seus versos, ou seja, com a falta de público. A voz personificada por Ariana ${ }^{63}$ - personagem mitológica, representa solidão e abandono remete ao outro ausente, Dionísio, entidade divina e também mitológica, que salva Ariana da solidão. ${ }^{64}$ Esses mitos, na figuração amado/amante, são representação de vozes reconfiguradas por Hilst no seu discurso, com o intuito de constituir sua palavra poética.

É possível, por meio dessas vozes, delinear alguns lugares em que a poesia de Hilst transita, para beber em suas fontes e depois transgredi-las. E isso é feito em sua poesia por um movimento de curto-circuito entre o tempo presente da obra e a tradição literária, como a dos românticos e de outras épocas e estilos. Como já afirmado, o espírito romântico pressupõe uma visão de mundo, cujo centro é o eu que, pela sua emoção, propõe-se a retratar o amor como drama humano. Na poesia de Hilst, de forma controversa, vemos uma pista que encaminha para essa constatação: o fato de referir-se

\footnotetext{
${ }^{63} \mathrm{Na}$ mitologia grega a princesa Ariadne ou Ariadna era filha de Pasífae e de Minos, rei de Creta, apaixonou-se por Teseu, herói grego, filho de Egeu, rei de Atenas, e o ajudou a destruir meio irmão, o monstruoso Minotauro, besta metade touro e metade homem, que habitava o labirinto sob o castelo de seu pai, filho de Pasífae com um touro branco. O jovem herói apresentou-se ao pai para e matar a fera. A princesa apaixonou-se por ele e receou que este morresse no labirinto, não conseguindo encontrar a saída. Então presenteou seu amado com um carretel de barbante e com a única espada capaz de matar o monstro. Teseu entrou no labirinto e à medida que caminhava ia soltando o fio, para achar a saída do labirinto após matar o Minotauro. A dificuldade maior não era o confronto com a besta, e sim achar o caminho de volta do labirinto, que só foi possível graças ao barbante. Teseu prometeu casar com ela e, cumprido a sua missão, ambos partiram de barco, mas este, ingratamente, abandonou-a à própria sorte na ilha de Naxos. O destino posterior de Ariadne é objeto de versões divergentes. Numa delas conta-se que, desesperada, atirou-se ao mar, procurando a morte e foi salva por Baco, que imediatamente se apaixonou por ela e com ela teve vários filhos e, depois que ela morreu, colocou no céu uma forma de uma coroa de estrelas, como lembrança do seu amor. E assim ela ficou conhecida como a imortal esposa do deus Dionísio. Disponível em: www.dec.ufcg.edu.br. Acesso em 20 de março de 2013.
}

64 Ao longo dos séculos, a história da princesa cretense foi tratada de modo diverso; porém, todos insistiram no tema da mulher seduzida e abandonada. Para alguns (Boccaccio), Teseu a teria abandonado porque estaria interessado em Fedra, outra filha de Minos, e, além disso, porque Ariadne em Naxos teria se embriagado e caído num sono profundo. A história da princesa também foi parar na literatura, na poesia (Corneille, Victor Hugo, Nikos Kazantazakis, Marguerite Yourcenar etc.), nas artes plásticas (Guido, Tiepolo e outros), na escultura (J.Dennecker).Disponível em: http://cidmarcus.blogspot.com.br/2011/10/teseu-ariadne-e-dioniso.html acesso em 20 março de 2013. 
ao amor e as suas relações conflituosas de uma forma peculiar, na qual o eu lírico busca, no interlocutor, uma forma de ser ouvido. Essa forma, aparentemente delineada, configura-se na negação da presença do interlocutor.

A voz poética, na obra em questão, mantém o desejo de tocar o outro por meio da interlocução, também, com as formas. As formas se dissolvem ao serem tocadas e se apresentam numa outra estrutura, cujo interlocutor assume a figura de Dionísio. Por ser a ode uma forma poemática que adota uma voz lírica destinada ao canto, na Ode de Hilst, Ariana, como representação do eu lírico, canta e exalta Dionísio em ausência. Vejamos como as questões acima citadas se configuram na primeira parte da Ode:

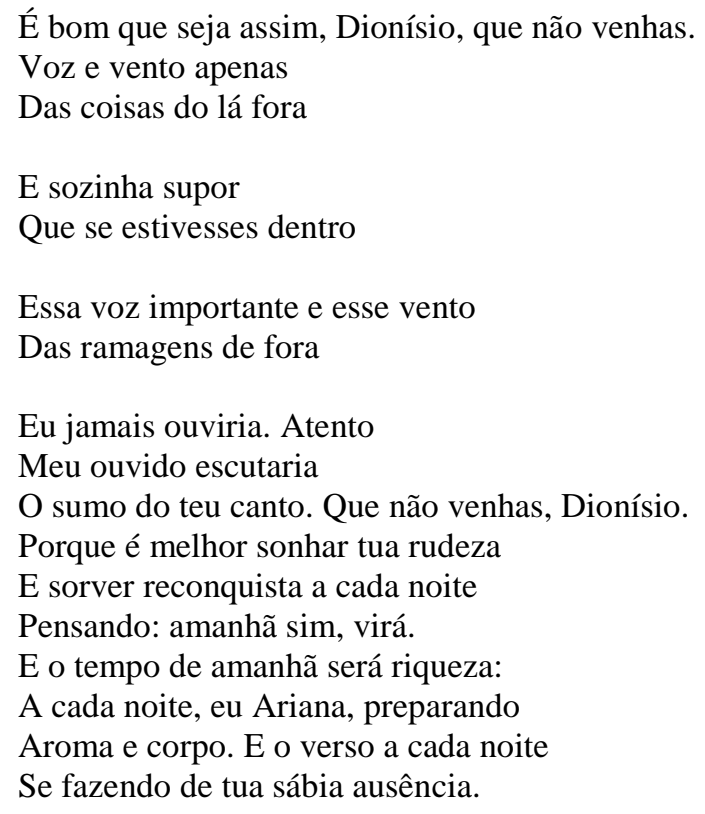

(HILST, 2003, p. 59)

Como se vê, esta parte da Ode é composta por quatro estrofes, dentre elas, um terceto, dois dísticos e uma estrofe de dez versos. O primeiro verso desrealiza a temática clássica da ode, de forma que seu sentido não se refere à exaltação de alguém e nem se faz como expressão de um sentimento amoroso: "É/ bom /que/ se/ja a/ssim,/ Dio/ní/sio,/ que /não /ven/has." Entretanto, a estrutura métrica desse verso é a preferida dos clássicos e dos parnasianos, por ser composto de 12 sílabas poéticas, alexandrino, cuja cesura se dá 
na sexta sílaba, dividindo-o ao meio e formando dois hemistíquios. Mesmo sendo os alexandrinos, versos que impõem a exaltação de sentimentos, o verso de Hilst propõe um tipo diferente de sentimento, como se fosse o de negar a exaltação de alguém ou de algo. O primeiro hemistíquio termina em "assim", advérbio de modo que indica como deve ser a vontade do eu lírico de dialogar com outras vozes, que, no segundo hemistíquio sentencia: "que não venhas" e reforça a ideia pelo vocativo, "Dionísio". O verso preconiza a vontade do eu lírico e encaminha para a negação da presença do amado, negando, com isso, a filiação de sua poesia a qualquer modo estabelecido de ser.

O verso propõe pistas de que há uma grande expectativa de o sujeito lírico, revestido de Ariana, ter a necessidade de exaltar a presença de Dionísio, pela sua ausência. A afirmativa é reforçada no terceiro verso da última estrofe “[...] que não venhas, Dionísio". O estado de espera de Ariana e os preparativos para a vinda de Dionísio colocam em tensão a construção do texto, cuja elaboração se fixa pela "sábia ausência" de Dionísio. A ideia da "sábia ausência" é percebida pelo corpo material da linguagem escolhida e pela sua constituição que se intensifica no decorrer do poema.

Há, no segundo verso, uma associação estabelecida entre o som da voz e do vento, marcado pela aliteração da consoante "v" estrofe e o primeiro verso da terceira estrofe. Essa combinação de palavras demonstra a consciência da passagem do tempo e metaforiza a presença de Dionísio feita pelo barulho do vento, que traz e leva o som de sua voz e dá fluência ao movimento de dentro e fora. "Voz e vento apenas/ Das coisas do lá fora". Nesse caso, o "fora" potencializa os versos no sentido de tornar possível o "dentro". Dizendo de outro modo, o "fora" sugere a possibilidade de diálogo com o suposto público, pelo qual o eu lírico cria uma espécie de transitividade entre o eu e o outro. O vento de fora, do qual o eu lírico prefere ouvir apenas

\footnotetext{
${ }^{65}$ Segundo Nilce Sant'Anna Martins, a consoante “v" como labiodental pode dar a ideia de fluição do verso. (1989, p. 35).
} 
a essência, a presença desse outro, Dionísio, fica só na imaginação, na ficção e no movimento de repetir-se: [...] "Que não venhas, Dionísio." "Porque é melhor sonhar tua rudeza / E sorver reconquista a cada noite".

$\mathrm{Na}$ terceira estrofe, o primeiro verso mostra uma construção de linguagem que sugere a poesia como canto em essência. Uma voz que serve como motivo para a criação da própria voz poética hilstiana, de elocução contundente com a noção do exterior, captada apenas pelo vento: "Essa voz importante e esse vento / Das ramagens de fora" e que vai tornar-se "sumo do canto", na quarta estrofe.

No início da quarta estrofe, o jogo entre a percepção, “ouviria”, e a tomada de consciência "escutaria", propõe a ideia de negação de uma presença do amado, e a necessidade de que a voz venha "de fora" e se torne audível como voz poética, "de dentro", para, a partir de então, poder entrar em cena a interlocução com Dionísio. A negação expressa pelo advérbio "jamais" é, também, quebrada pelo ponto final: "Eu jamais ouviria. [...]” para em seguida criar um enjambement: “[...] Atento / Meu ouvido escutaria/ O sumo do teu canto.” Temos, neste caso, a constituição de uma voz que só se faz audível perante a desagregação do ouvinte em resíduo, de corpo ausente. Esse procedimento propõe o sentido tanto de intensificação incisiva da ideia a ser expressa, quanto de continuidade para chegar ao ponto alto da construção poética desses versos, o que é feito pela ausência de Dionísio.

O jogo entre presença e ausência de Dionísio quer reverberar também a presença e a ausência de um lirismo centrado no "eu" "anímico"66, como idealização amorosa, na figura da mulher ideal e fiel, que expressa sofrimento pela não realização do amor, próprio da lírica romântica. No poema de Hilst, estes traços românticos se apresentam apenas

\footnotetext{
${ }^{66}$ Refere-se ao estado de alma, "anímico", como expressão da alma do poeta. Termo utilizado por Staiger em Conceitos fundamentais da poética, (1975).
} 
como simulacro. Não há a preocupação em consolidar um amor ou expressar uma dor pela falta.

Para melhor elucidar essa proposta de compreensão da lírica hilstiana, nestes versos, mencionamos o poema "Leito de folhas verdes" de Gonçalves Dias ${ }^{67}$. Só que, ao contrário do poema de Dias, o eu lírico de Hilst, neste poema, não se prende à espera que se prolonga e à angústia crescente pela ausência do amado, como se vê no poema de Dias, porque em Hilst, essa ausência é necessária. Vejamos o poema de Dias:

Por que tardas, Jatir, que tanto a custo À voz do meu amor moves teus passos? Da noite a viração, movendo as folhas, Já nos cimos do bosque rumoreja.

Eu sob a copa da mangueira altiva Nosso leito gentil cobri zelosa Com mimoso tapiz de folhas brandas, Onde o frouxo luar brinca entre flores.

Do tamarindo a flor abriu-se, há pouco, Já solta o bogari mais doce aroma! Como prece de amor, como estas preces, No silêncio da noite o bosque exala.

Brilha a lua no céu, brilham estrelas, Correm perfumes no correr da brisa, A cujo influxo mágico respira-se Um quebranto de amor, melhor que a vida!

A flor que desabrocha ao romper d'alva Um só giro do sol, não mais, vegeta: Eu sou aquela flor que espero ainda Doce raio do sol que me dê vida.

Sejam vales ou montes, lago ou terra, Onde quer que tu vás, ou dia ou noite, Vai seguindo após ti meu pensamento; Outro amor nunca tive: és meu, sou tua!

Meus olhos outros olhos nunca viram, Não sentiram meus lábios outros lábios, Nem outras mãos, Jatir, que não as tuas A arazóia na cinta me apertaram.

${ }^{67}$ Leito de Folhas Verdes, poema do movimento romântico brasileiro, de autoria de Gonçalves Dias. O poema enseja uma declaração de amor, em que predomina a angústia de quem espera. O eu lírico é feminino faz o relato de seus sentimentos e pensamentos, num tempo a princípio cronológico, que começa com a chegada da noite e vai até o amanhecer do outro dia. 
Do tamarindo a flor jaz entreaberta,

Já solta o bogari mais doce aroma

Também meu coração, como estas flores,

Melhor perfume ao pé da noite exala!

Não me escutas, Jatir! nem tardo acodes

À voz do meu amor, que em vão te chama!

Tupã! lá rompe o sol! do leito inútil

A brisa da manhã sacuda as folhas! ${ }^{68}$

A remissão às formas e motivos deste poema de Dias serve para repensar a voz lírica hilstiana. O primeiro verso de cada poema: "Por que tardas, Jatir, que tanto a custo" e "É bom que seja assim, Dionísio, que não venhas", remontam a dois tipos diferentes de espera, como motivo de constituição lírica: Jatir e Dionísio são interlocutores imaginados para que o eu lírico mobilize o seu discurso poético. Em Dias, a voz que canta a ausência reforça a necessidade da presença: "Por que tardas, Jatir, [...]" e sofre por ela, porque é submissa a ela; em Hilst, a ausência é necessária: "É bom que seja assim, Dionísio, que não venhas". O eu poético de ambos os poemas não diz apenas por si mesmo, mas sim por meio de seus interlocutores imaginados. No caso do poema de Hilst, a voz lírica não torna útil a figura materializada de Dionísio como alvo de constituição da comunicação poética, o que estabelece um contradiálogo que foge à expectativa da relação amorosa expressa no poema de Dias.

Hilst infere uma voz centrada em si, mas também dialoga com outras formas poemáticas, como é o caso em que, na macroestrutura do seu poema, a predominância são os versos de dez silabas poéticas, sobretudo na última estrofe. Quanto ao ritmo, os quatro últimos versos do poema hilstiano remontam semelhantes aos versos de "Leito de folhas verdes". São versos decassílabos heroicos, cujas cesuras se dão na $6^{\mathrm{a}}$ e $10^{\mathrm{a}}$ sílabas poéticas, e cujos motivos remetem a uma consciência temporal pelas marcas das palavras:

\footnotetext{
${ }^{68}$ Leito de folhas verdes. In: DIAS, Gonçalves. Poesia e prosa completas. Rio de Janeiro: Aguilar, 1998. p. 377-8.)
} 
em Hilst: "noite", "amanhã"; em Dias: "romper d'alva", "giro do sol”, como se vê a seguir:

$$
[\ldots]
$$

E o tempo de amanhã será riqueza:

A cada noite, eu Ariana, preparando

Aroma e corpo. E o verso a cada noite

Se fazendo de tua sábia ausência.

(HILST, 2003, p.59)

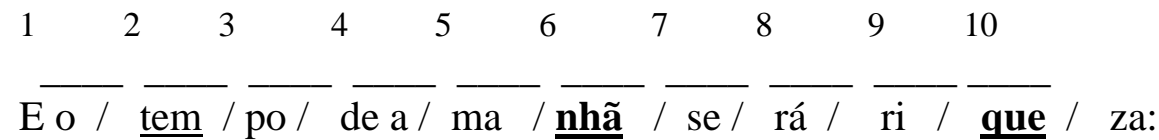

$[\ldots]$

A flor que desabrocha ao romper d'alva

Um só giro do sol, não mais, vegeta:

Eu sou aquela flor que espero ainda

Doce raio do sol que me dê vida.

(DIAS, 1998. p. 377)

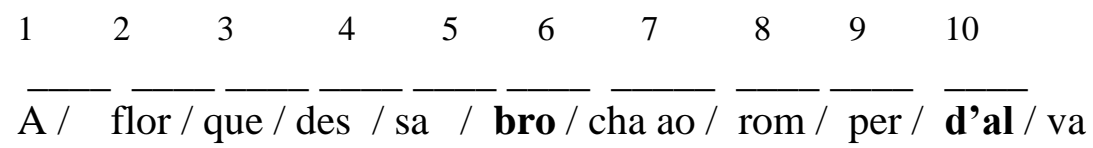

Além da coincidência formal dos versos, temos, nos dois poemas, uma estrutura movida pela espera, mas em Hilst, retomando o que já foi dito, não há o lamento pela ausência, como força motriz. Isso é percebido pela entonação dos versos do poema, cujas formas rítmicas desmancham a expectativa e o lamento. Em Dias, há a expectativa frustrada do sujeito lírico que sofre de amor. No poema de Hilst não há frustração, pelo contrário, no último verso do poema há a consciência do que se faz como afirmação no primeiro verso: “É bom que seja assim, Dionísio, que não venhas.” [...] "E o verso a cada noite / Se fazendo de tua sábia ausência. Em "Leito de folhas verdes", o eu lírico tem a consciência do tempo como fator que movimenta o poema, por meio da linearidade temporal, pautado na espera angustiosa pelo amado, que desemboca no desenredo de uma paixão, cuja expectativa é frustrada, porque Jatir não vem. Por isso, há um derramamento de tristeza e solidão do eu lírico. Em ambos os poemas, a elocução, mesmo de maneira 
distinta, é o sentimento e a consciência da elaboração artística por meio da espera do amado.

Na última estrofe do poema hilstiano, o movimento de dentro e fora se intensifica e dá a ideia do exercício contínuo de constituição textual do poema, movido por várias construções que nele aparecem. Uma delas é a sequência de verbos no gerúndio, "pensando, preparando, fazendo", sempre acompanhados pelo procedimento de enjambement, “[...] preparando / Aroma e corpo. E o verso a cada noite / Se fazendo[...]”. Esses procedimentos dão ritmo ao verso por meio de um movimento repetitivo e circular, de fazer e refazer. $\mathrm{O}$ aspecto sonoro do gerúndio também remete à passagem do tempo. Junta-se a esses verbos a combinação "a cada noite", que se repete por três vezes na última estrofe, completando o movimento cíclico da passagem do tempo.

Outro índice que expressa a ideia do repetir-se em movimento cíclico em torno de si é o substantivo "reconquista", que reforça o signo da espera e dá importância à ausência de Dionísio como objeto de desejo de construção do poema. A cada ciclo temporal, que no poema refere-se "a cada noite", o mesmo processo é realizado. O movimento contínuo do verbo "preparando" alimenta a espera da presença que é ausência, como força de constituição lírica.

Observando os dois poemas com atenção, podemos constatar que há uma articulação dos elementos de linguagem dos quais ambos os poemas se utilizam para dar sentido poético aos seus versos. A "espera" como palavra lírica, os preparativos, a movimentação cíclica para a vinda ou não vinda dos seus interlocutores vai sendo construída lentamente, como o "sorver", gole a gole, até absorver as palavras na forma poética. No quinto verso, do poema de Hilst o verbo "sorver" indica um movimento de absorver a reconquista todas as noites. "Porque é melhor sonhar tua rudeza / E sorver 
reconquista a cada noite". Esses versos reforçam, na lírica hilstiana, o signo da espera e a importância da ausência de Dionísio.

Para além dos procedimentos de linguagem que Dias e Hilst estabelecem na constituição de seus poemas notamos a proximidade na forma retórica do texto, no que se refere ao processo interlocutivo dos poemas e seu destinatário. No entanto, a linha de força, no caso de Hilst, sobretudo nesta Ode, é a de enfatizar o tipo de voz que emana do eu lírico e nela se fixa. Ariana, personagem inventada para tecer a teia da poética da ausência. Nessa poética, Ariana se impõe mais como poeta do que como amante, porque, na presença de Dionísio, ela se torna amante e a falta a faz poeta. A parte II da Ode assim se configura:

\title{
II
}

\author{
Porque tu sabes que é de poesia \\ Minha vida secreta. Tu sabes, Dionísio, \\ Que a teu lado te amando, \\ Antes de ser mulher sou inteira poeta. \\ E que o teu corpo existe porque o meu \\ Sempre existiu cantando. Meu corpo, Dionísio, \\ É que move o grande corpo teu. \\ Ainda que tu me vejas extrema e suplicante \\ Quando amanhece e me dizes adeus. \\ (HILST, 2003, p. 60)
}

Diante de um poema é preciso ter sempre uma atitude de desconfiança porque nele tudo é experiência que pensa de todo modo o ser em conexão discursiva com outros elementos que o constituem. A modernidade instalou uma poesia cujo status é verter-se criticamente em relação ao passado, rompendo com os paradigmas até então propostos. A partir dessa ruptura foi preciso que a poesia reinventasse novas formas de chamar a atenção sobre si. Com isso, a constituição da subjetividade tornou-se conflituosa, já que o "eu" lírico passa a ser "sujeito" lírico; a primeira pessoa sai de cena para dar lugar à impessoalidade. A esse respeito, Siscar, 2011, estudo desenvolvido sobre a poesia de Ana Cristina Cesar, afirma que na poesia moderna não cabe a primeira pessoa e que, "na poesia 
brasileira, a questão voltou a ganhar um caráter decisivo e problemático com a geração de Ana C.[...] ela reagiu à predominância da visão objetiva e artesanal da poesia associada à figura de João Cabral de Melo Neto.” (2011, p. 16).

Esse caráter "problemático" de que fala Siscar é visto como uma das linhas de força em Hilst. Nos versos da segunda parte da Ode há uma forma própria de pensar a arte, por meio de uma voz feminina que transpõe o simples jorrar de sentimentos. A atitude de espera e súplica ao amado ausente não se refere unicamente a um "eu" como centro de reflexão, como no modelo romântico de lírica; a voz do "eu" se faz da atitude reflexiva em relação ao status da poesia, que não é só a espera do amante, mas um desejo de ausência e por ele fazer nascer a palavra, o verso: "Antes de ser mulher sou inteira poeta."

Esta segunda parte é composta por duas estrofes, uma de sete e outra de dois versos, nos quais, quanto à métrica, predominam os decassílabos e os alexandrinos. No primeiro verso há um decassílabo que forma um enjambement com o segundo verso o qual, por sua vez é alexandrino; apresenta cesura na quarta, oitava e décima sílabas, sendo, portanto, decassílabo sáfico. O quarto e o quinto versos são decassílabos heroicos, apresentam esquema rítmico na sexta e na décima sílabas; o último verso do poema é uma desdefinição da forma clássica de verso, porque, mesmo sendo decassílabo, não se prende a nenhum esquema rítmico, apresenta cesura na quarta, sétima e décima sílabas.

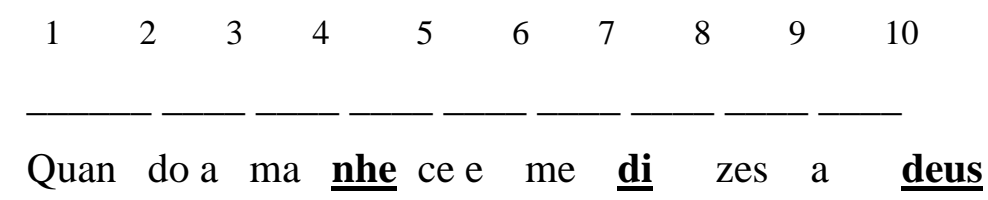

Essa forma de construção sugere que não há uma preocupação explícita em reiterar criticamente as formas clássicas de versificação. Hilst se apodera de uma voz que 
se alimenta das leitura que faz e fala para si, sem premeditar de forma incisiva um diálogo com essas formas. Os temas e motivos provam esse artifício da voz da poeta ao buscar a figura clássica e mítica de Dionísio, para validar uma proposta de diálogo às avessas, um diálogo que é monólogo, com o aspecto estrutural do poema. As formas e seus recursos estilísticos são retomados como tentativa de simular apenas uma parecença com os elementos estruturais tradicionais do poema. Para isso, o eu lírico se apropria de procedimentos como o uso do enjambement, que se repete nesta parte da Ode. Isto é, uma espécie daquilo que não cabe em um verso apenas e que precisa ter continuidade no verso seguinte. Nos quatro primeiros versos ocorre um ciclo de significância por meio desse procedimento:

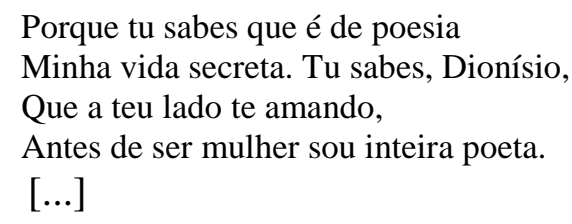

Esses quatro versos fecham um ciclo sintático que também é semântico, pelo uso da conjunção "porque” no início do primeiro verso, dando a ideia de uma explicação para atuação da voz poética nesses versos. Interessante é o uso das conjunções iniciais neste poema. O primeiro verso inicia com a conjunção explicativa "porque", tanto para dar continuidade à parte I da Ode, dos seus últimos versos “[...] E o verso a cada noite / Se fazendo de tua sábia ausência.", como também para reforçar a ideia de que o mais importante não é somente a ausência, nem a presença, nem o amor, nem a espera por Dionísio. É a construção da poesia que importa, e a maneira como as palavras são selecionadas e combinadas no poema.

Tanto na primeira parte da Ode como na segunda, a tensão materializa-se em forma e expressão poética e remete ao anúncio de independência num momento bastante peculiar da consciência da voz feminina em relação ao amado. Essa voz se impõe como 
modo de afirmação de que a poesia é o que importa e ela é também ausência construída da "sábia ausência" do amado. Esse procedimento discursivo retoma a figura do eu lírico como alguém que não está aprisionado à individualidade como é caso do eu-lírico romântico, para lembrar, em Gonçalves Dias, o poema "Leito de folhas verdes", que configura uma espera do sujeito lírico feminino, ensimesmado, e também sofre a ausência do amado, mas se alimenta da espera, mesmo sem materializá-la: "Um quebranto de amor, melhor que a vida! / A flor que desabrocha ao romper d'alva / Um só giro do sol, não mais, vegeta:/ Eu sou aquela flor que espero ainda / Doce raio do sol que me dê vida.”(DIAS, Gonçalves). Na poesia de Hilst há a recusa da ausência como única fonte amorosa, e por isso, impõe um tipo de subjetividade lírica que não a dos românticos.

Os três últimos versos da primeira estrofe da parte dois da Ode formam o segundo bloco de significação, ligados entre si pela conjunção “e”, dando ideia de complemento aos motivos desenhados no primeiro bloco de versos:

\section{$[\ldots]$}

E que o teu corpo existe porque o meu Sempre existiu cantando. Meu corpo, Dionísio, É que move o grande corpo teu.

$[\ldots]$

Estes versos apresentam o interlocutor, Dionísio, como um ser fictício, porque o seu corpo só existe por intermédio do canto de Ariana. Vemos que o outro se estabelece por meio da palavra corpo, expressa não só na figura de Dionísio, mas no corpo da palavra como significante, sob o qual se depositam sentidos poéticos. "E que o teu corpo existe / porque o meu sempre existiu cantando. Meu corpo, Dionísio, / É que move o grande corpo teu." O corpo de Ariana, ao cantar, interioriza com a força da poesia o corpo de Dionísio. Desta forma, o corpo é ícone de conexão do poeta com a linguagem. Assim como nos versos da primeira parte da Ode: “A cada noite, eu Ariana, preparando /Aroma e corpo. 
E o verso a cada noite / Se fazendo de tua sábia ausência", essa relação corpo/palavra revela o ato da preparação "aroma e corpo" e se faz da ausência que é também presença enquanto discurso. Um corpo que é também alma.

A última estrofe iniciada pela locução conjuntiva concessiva, "ainda que”, permite reforçar e acrescentar mais um argumento para o poema: "Ainda que tu me vejas extrema e suplicante / Quando amanhece e me dizes adeus." Esses versos demonstram o eu lírico numa cena cara à sua constituição poética, ou seja, ao ciclo criado por Hilst, no movimento de supremacia do eu lírico como forma de se colocar ao seu interlocutor, Dionísio, que também pode ser o seu leitor, em situação de subserviência.

O poema se organiza, portanto, em três esquemas sintáticos: os primeiros quatro versos formam o bloco que expressa uma tentativa de explicação do canto de Ariana; o segundo bloco, os três últimos versos da estrofe, reforçam a ideia de adição à explicação do primeiro, sintática e poeticamente, pela conjunção aditiva “e”. E o último bloco se faz pelos dois versos da última estrofe, reforçando a figura de Dionísio de "corpo ausente", já que ele é um ser fictício, criado para ser mot de sua poesia, isto é, que seu corpo só existe por intermédio do canto.

Dessa forma, é pertinente dizer que o poema em tela conota uma voz interlocutiva com o amado para criar uma poesia composta pela "tríade imagética poesia-cantocorpo" ${ }^{69}$. E acrescentaríamos que essa tríade só é possível, no processo criativo hilstiano, por meio desse interlocutor. É ele que produz na voz criadora de Hilst, no papel de Ariana, uma dupla voz: a da mulher e a da poeta.

\footnotetext{
${ }^{69}$ Expressão utilizada por Karyni P. de Moura em seu artigo: Hilda Hilst e o canto da Mulher Selvagem: um olhar pela Crítica do Imaginário.

Disponível em: http://www2.assis.unesp.br/cilbelc/jornal/julho08/content12.html. Acesso em 13 de outubro de 2015.
} 
Nesse ponto de vista, a segunda parte da Ode tange a tensão da incompletude no amado, Dionísio, pela supremacia da voz lírica de Ariana, que dita as regras no jogo amoroso de sedução. Mas frente a isso, essa voz sente em si uma força perante a implacabilidade do devir: o canto da poesia. Coelho, 1999, em ensaio que trata da poesia de Hilst, reforça que uma das linhas de força da poesia hilstiana é o desejo constante do amor e a necessidade de nomeá-lo, por meio de uma relação amado/amante conflituosa. Nessa relação há a constante luta "gerada pela ânsia incontida de um eu em busca da fusão plena com o outro." (1999, p. 66). E por essa relação do eu com o outro perpassa o que está posto na quarta parte da Ode:

IV

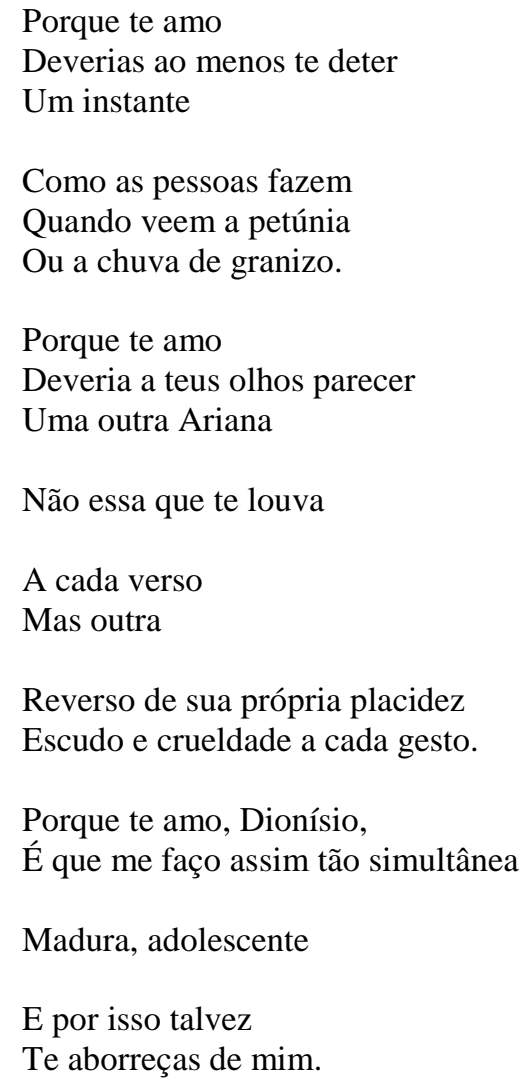

A composição das estrofes nesta parte da Ode propõe um ritmo dosado pela metrificação na qual predominam os versos de seis e dez sílabas. As três primeiras estrofes são de três versos e as demais são de dois e um versos cada. A estrofe central do 
poema de apenas um verso, "Não essa que te louva", sugere um marco divisório entre as estrofes anteriores e posteriores a ele, tanto pela forma quanto pelo conteúdo. Este divide o poema na mesma quantidade de versos acima dele e abaixo: são nove versos acima e nove abaixo.

Notamos a inseparabilidade da forma e do sentido: do ponto de vista formal, essa disposição, tendo o verso citado como central, evidencia uma reflexão sobre a identidade da ode clássica, que era composta por um poeta com a intenção de "louvar" alguém ou um acontecimento que merecesse honrarias. No caso do poema de Hilst, o eu que louva, na figura de Ariana, acaba sendo o seu próprio reverso, uma mistura de anjo e demônio: “Reverso de sua própria placidez / Escudo e crueldade a cada gesto". O jogo sonoro entre as oclusivas surdas, apresentado pela expressão "própria placidez" [p], indica a personificação de uma outra Ariana mais “cruel”, movida pela paixão avassaladora. O mesmo acontece em "Escudo e crueldade a cada verso", a aliteração em [k] produz uma obstrução da fluidez dos sons da voz, que nos versos seguintes volta à mansidão: "Porque te amo, Dionísio / É que me faço assim tão simultânea / Madura, adolescente”. Vemos, novamente, neste poema, o eu-no-outro: a outra, criada ficcionalmente pela poeta para instaurar sua voz lírica.

A ideia de amor romântico aparece representada e desrealizada pelo eu lírico, porque ele brinca com essas noções quando diz, nos versos "É que me faço assim tão simultânea / Madura, adolescente". O eu lírico adquire, no decorrer do poema, mais de uma voz: a que louva e a que é o seu reverso, a madura e a adolescente. Cada uma, a seu modo, inconstante na forma de "louvar" por meio do canto e de chamar a atenção de Dionísio.

Temos, portanto, a presença de dois eus diferentes, que se projetam um no outro e se tornam um só. Esses eus são gerados pela simultaneidade da passagem do tempo e 
do instante: as duas coisas acontecem num fluxo não só de vozes mas de tempo, e ao mesmo tempo, no mesmo instante. Na primeira estrofe, o verso "Deverias ao menos te deter um instante", coloca a representação do eu, Ariana, em evidência e não somente o amor que, supostamente, sente por Dionísio. É como se dissesse: porque $e u$ te amo e não por você. A expressão "Porque te amo" é repetida em versos iniciais de três estrofes do poema, como uma espécie de refrão, para tornar-se mais audível ao seu interlocutor. Na última vez que a expressão aparece no poema, vem acompanhada do vocativo "Dionísio", como na função fática da linguagem. Mais uma vez a voz se coloca em evidência e quer chamar a atenção para si. A voz de Ariana é movida pela inconstância e pelo duplo da alma.

Retomando a segunda estrofe do poema, o eu lírico lança mão de imagens como "petúnia" e "chuva de granizo", imagens que lembram a inconstância do eu lírico, mobilizadas nestes versos. Petúnia é uma planta ornamental, que não se adapta ao sol muito quente, produz muitas flores coloridas, mas não duram muito tempo abertas, porque são frágeis. A “chuva de granizo", também é passageira, contudo, é torrencial e destrói as coisas por onde passa. Essas imagens aliam-se à representação do eu lírico dúbio, assim também com o verso "Madura, adolescente", sente necessidade de ser visto e ouvido pelo interlocutor Dionísio, mesmo não esperando dele nenhuma reação.

Os últimos versos desta parte da Ode, "E por isso talvez / Te aborreças de mim”, indicam para o universo discursivo do texto, por meio do pronome "isso". Demonstram a constituição do poema como indicativo da supremacia da voz hilstiana ao referir-se, pelo pronome "te", ao seu interlocutor, Dionísio. 


\section{1.“Minha extensa e difícil dialética lírica" 70}

Nenhum artista tem seu significado completo sozinho, é o que retoma Affonso Romano de Sant'Anna no prefácio ao livro A essência da poesia de Eliot. (1972, p.22), citando o ensaio "Tradição e talento individual", do mesmo autor. De acordo com esse pensamento, a poesia, como também as outras artes, sofre, o tempo todo, intervenções de outros discursos que desencadeiam uma rede de reflexões. O ponto culminante dessa “difícil dialética lírica" demarca, sobretudo, a experiência da intimidade do eu em relação à experiência da poesia. E, por conseguinte, dessa relação se configura uma voz dramática, que se apodera das outras vozes de que fala Eliot no ensaio citado no início do capítulo. Podemos dizer que esse fluxo de vozes permite ouvir não apenas uma, mas várias vozes.

Em júbilo, memória, noviciado da paixão, e sobretudo na Ode, as várias vozes estabelecem um vínculo com o passado remoto e torna-o um presente contínuo ${ }^{71}$ que se alimenta, no caso da poesia, da expressão amorosa de um eu para um tu imaginado. Ao buscar na forma ode a inspiração para seus versos, Hilst busca interlocução com o sentido primeiro desta forma poemática, que é o de versar em tom alegre e entusiástico. Todavia, o tema tratado nesta obra não é de tom eufórico, mas de inquietude desvelada nos poemas ditos "amorosos". Na parte VIII, isso assim se configura:

VIII

Se Clódia desprezou Catulo E teve Rufos, Quintius, Gelius Inacius e Ravidus

Tu podes muito bem, Dionísio, Ter mais cinco mulheres E desprezar Ariana

\footnotetext{
${ }^{70}$ Verso que compõe a seção VII da Ode, p.65.

${ }^{71}$ Referimo-nos ao entendimento do título "Ode descontínua e remota para flauta e oboé: De Ariana para Dionísio".
} 
Que é centelha e âncora

E refrescar tuas noites

Com teus amores breves.

Ariana e Catulo, luxuriantes

Pretendem eternidade, e a coisa breve

A alma dos poetas não inflama.

Nem é justo, Dionísio, pedires ao poeta

Que seja sempre terra o que é celeste

E que terrestre não seja o que é só terra.

(HILST, 2003, p. 66)

Nessa parte da Ode, há novamente o procedimento de continuidade da parte VII, que assim termina: "E ensinar à mulher e a ti, Dionísio, /A eloquência da boca nos prazeres / E plantar no teu peito, prodigiosa / Um ciúme venenoso e derradeiro.” (HILST, 2003, p. 65$)^{72}$. Reportamo-nos a algumas questões da parte VII, para que isso seja compreendido: o eu lírico coloca-se em condição de mestre da arte de amar, mas não da arte de poetar: "Canção e liberdade não se aprendem". Já nas duas primeiras estrofes da seção VIII, a construção dos versos está pautada no processo de busca de vozes da tradição, mencionando figuras como a de Clódia e Catulo. Essa relação remete a aspectos da lírica amorosa, mas às avessas, porque nos dois poemas há um tom da sentimentalidade provocada pelo ciúme, que é veneno e que mata: "Um ciúme venenoso e derradeiro." e: "Se Clódia desprezou Catulo"[...] "Tu podes muito bem, Dionísio, /Ter mais cinco mulheres". Os últimos versos da seção VIII, acima citados, são repositórios da voz lírica de Hilst, constituída por outras vozes buscadas na tradição. A referência a Catulo ${ }^{73}$, poeta

\footnotetext{
${ }^{72}$ Parte VII do livro: "É lícito me dizeres, que Manan, tua mulher/Virá à minha Casa, para aprender comigo /Minha extensa e difícil dialética lírica? /Canção e liberdade não se aprendem /Mas posso, encantada, se quiseres/ Deitar-me com o amigo que escolheres /E ensinar à mulher e a ti, Dionísio, /A eloquência da boca nos prazeres/ E plantar no teu peito, prodigiosa /Um ciúme venenoso e derradeiro.”(HILST, 2003, p. 65)

${ }^{73}$ Catulo pertenceu a um grupo de poetas e intelectuais que, nos meados do século 1 a.C., rompeu com o passado literário romano, segundo João Ângelo de Oliva Neto. Daí as críticas que tal grupo recebia, por exemplo, de Cícero, que os chamava, ironicamente, de "poetas novos". Os poemas longos de Catulo apresentam diversidade de metrificação. Quanto às peças curtas, nelas se destacam os epigramas elegíacos. Sua obra tem nítida influência dos modelos alexandrinos. E, em alguns casos, é evidente o uso que ele faz - verdadeira transposição - de poemas escritos por gregos, como Calímaco.
} 
romano, que no poema em tela constitui a personificação da poeta, configura-se como mais uma voz que Hilst conclama para materializar a conformação de sua poesia.

Existe, nestes versos, o convite da voz de Ariana para o amor pleno, intermediado pela memória, e busca irmanar-se a Catulo. Oliveira, (2013) ${ }^{74}$, em artigo que trata da memória como forma de reiteração significativa, infere que: “A memória é, assim, a historicidade da vida, que capta as formações discursivas como excesso do que se queria fazer, dizer e pensar, excesso que abre aos outros a possibilidade de retomada e de criação.” (2013, p.65) As várias conexões que a poesia de Hilst faz com o passado, por meio da memória, traz significações para sua poesia e demostra, de um lado, a constituição do repertório de leituras que a poeta encena em sua poesia; de outro, a utilização desse procedimento como permanência e até legitimação da sua voz lírica, carente de um destinatário a quem possa se dirigir, falando de si própria.

Neste caso, Dionísio não se configura como único interlocutor, mas várias outras personas são invocadas, tendo a voz de Catulo como modelo. As figuras ${ }^{75}$ referendadas

Catulo inaugurou na literatura romana uma forma nova - o poema leve, gracioso e elegante, para preencher uma lacuna existente entre a tragédia e poema épico de um lado, e a comédia e a sátira do outro. Ele exerceu considerável influência sobre seus sucessores romanos - e também sobre Ovídio, Horácio e Marcial. Tornou-se, assim, o maior poeta lírico da Roma antiga. Foi um dos primeiros poetas a incorporar elementos da paisagem a seu mundo verbal, como reflexo de sentimentos pessoais. Seus poemas, muitas vezes, parecem falar de emoções próprias do homem ocidental contemporâneo.

(Enciclopédia Mirador Internacional; O livro de Catulo (Edusp, 1996); Dicionário Oxford de Literatura Clássica. http://educacao.uol.com.br/biografias/catulo.htm.). Acesso em 14 de outubro de 2014.

${ }^{74} \mathrm{O}$ autor trata, neste artigo da memória como modos de "mais significar" ou de reiteração significativa. Escolhe como leitura para essas questões alguns poemas de Júbilo, memória, noviciado da paixão, para enfatizar questões como "intuição e gozo, libido e alteridade, diferença e erotismo".

75 Segundo Luiza Destri em sua dissertação de mestrado, 2010, Rufus é figura de quem Catulo havia sido amigo e a quem acusa de traição. Quintius e Inacius são êmulos do poeta, destinatários de poemas satíricos. O segundo é definido como "Egnácio, a quem faz lindo espessa barba/ e dentes limpos com urina Ibérica", e ao primeiro se dirigem os seguintes versos: "Se queres, Quíntio, que te dê Catulo os olhos, / ou mais, se algo mais caro há que seus olhos, / não vás tolher o que é muito mais caro a ele/ que seus olhos, se algo há mais caro que olhos". A Gelius, "persona de um rival, que fora companheiro do eu lírico catuliano", dedicase todo um ciclo de poemas, na atualização da "tópica do amigo transformado em inimigo". Já Ravidus é destinatário dos seguintes versos: "Que queres? Ser notado a qualquer custo? / Serás! porque quiseste meus amores/ amar, então terás longo castigo”. 2010, p. 95. 
na primeira estrofe representam adversários de Catulo, com os quais Clódia ${ }^{76}$ o traiu, fato que deve ter provocado os ciúmes de Catulo. Nos três versos desta primeira estrofe, o eu lírico recorre a esse mosaico de vozes para legitimar a sua condição de mulher abandonada, e usa esse artificio para se fazer de vítima, e com isso, sentir-se na posição de poder igualar-se a essas vozes da tradição grega. Ao iniciar com a conjunção "se", o verso impõe uma necessidade de buscar interlocução com as várias vozes para se fazer audível e abre a possibilidade de comparação com outros tempos e outros espaços.

Nas primeira e segunda estrofes, há algo curioso no aspecto estrutural, em relação ao ritmo e ao número de sílabas poéticas: os três primeiros versos da segunda são idênticos aos da primeira estrofe, isto é: possuem oito e seis sílabas poéticas, cujas cesuras se dão sempre nas mesmas sílabas $\left(2^{\mathrm{a}}\right.$ e $8^{\mathrm{a}}, 2^{\mathrm{a}}$ e $\left.6^{\mathrm{a}}\right)$ :

$$
\begin{aligned}
& \frac{1}{\text { Se }} \frac{2}{\text { Cló }} \frac{3}{\text { dia }} \frac{4}{\text { des }} \frac{5}{\text { pre zou }} \frac{6}{\mathrm{Ca}} \frac{7}{\mathbf{t u} \text { lo }}
\end{aligned}
$$

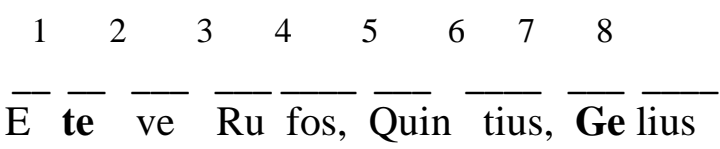

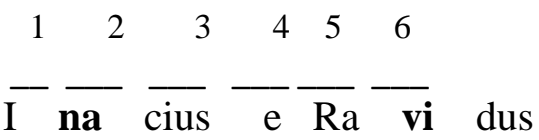

$$
\begin{aligned}
& \frac{1}{\text { Tu }} \frac{2}{\text { po }} \frac{3}{\text { des }} \frac{4}{\text { mui }} \frac{5}{\text { to }} \frac{6}{\text { bem, Dio }} \frac{7}{\text { ní sio, }} \\
& \frac{1}{\text { Ter mais }} \frac{2}{\text { cin }} \frac{3}{\text { co }} \frac{5}{\text { um }} \frac{6}{\text { lhe }} \text { res } \\
& \frac{1}{\mathrm{E}} \frac{2}{\operatorname{des}} \frac{3}{\text { pre }} \frac{4}{\text { zar }} \frac{5}{\mathrm{~A}} \frac{6}{\text { ria }} \text { na }
\end{aligned}
$$

\footnotetext{
${ }^{76}$ Clódia foi amante de Catulo, senhora romana de boa linhagem, era casada e fazia parte de uma sociedade na qual as conhecidas virtudes haviam desaparecido. Por isso, Catulo lhe dá o nome de Lésbia. Ela era muito inconstante, traiu Catulo com seu melhor amigo, Rufo. Informações obtidas em http://klepsidra.blogspot.com.br/2005/04/catulo-e-lsbia.html. Acesso em 13 de outubro de 2014.
} 
Já o quarto verso da segunda estrofe: "Que é centelha e âncora”, composto por quatro sílabas poéticas, destoa da métrica e da musicalidade dos demais, para impor-se como aspecto formal, ao mesmo tempo em que se impõe como voz estabelecida entre o desejo corpóreo, "centelha", e a racionalidade, "âncora". Por meio de termos como esses, caros à poética de Hilst nos livros selecionados para o presente estudo, vemos mais uma vez que sua voz lírica se faz das várias tensões.

O poema remete tanto à ideia de perpetuação da poesia quanto à reflexão sobre a postura do eu lírico na construção do poema. Para entender um pouco mais sobre isso, vemos que no prefácio ao livro "A verdade da poesia”, 2007, Michael Hamburger, ao indagar sobre o que torna moderna a poesia, chama a atenção para o fato de que é moderna aquela que apresenta tensões e conflitos visíveis. Ao tratar sobre a importância da articulação da linguagem na poesia afirma que "A verdade da poesia, e da poesia moderna especialmente, deve ser encontrada não apenas nas suas afirmações diretas, mas em suas dificuldades peculiares, atalhos, silêncios, hiatos e fusões.” (2007, p. 62). Por esse viés, a lírica de Hilst estabelece um tipo de "verdade" pela necessidade não de fusão com outros tempos e outros espaços, mas conclama a presença de Catulo como que para uma espécie de validação de sua voz lírica, no que se refere ao seu interlocutor, Dionísio.

O último verso da terceira estrofe, "Ariana e Catulo, luxuriantes" e os dois primeiros da quarta estrofe, "Pretendem eternidade, e a coisa breve/ A alma dos poetas não inflama", inferem-se, sintática e semanticamente, na estruturação do poema, como início de uma segunda parte, a que o eu lírico coloca como centro a ideia de interlocução com Catulo, para materializar a interlocução com Dionísio. Chama-nos a atenção o significado da palavra "luxuriante": "que produz com grande engenho; que demonstra riqueza criativa", ou, que se desenvolve com grande riqueza e vigor ${ }^{77}$; enquanto a palavra

\footnotetext{
${ }^{77}$ Dicionário Eletrônico Houaiss da língua portuguesa.
} 
da qual ela deriva, "luxúria”, significa viço, e, segundo a doutrina cristã, é um dos sete pecados capitais que prevê um comportamento desregrado com relação aos prazeres do sexo. Logo, o verso "Ariana e Catulo, luxuriantes" prevê uma relação entre Ariana e Catulo, movida por um desejo sob o qual é possível fazer nascer a poesia fixada no diálogo com a tradição.

Em consequência dessa relação desejosa que o poema mostra, entre Ariana e Catulo, vemos que a poesia se eterniza, porque está pautada na tensão entre o inteligível e o sensível. Sobre a fusão desses dois polos da constituição poética estão outros aspectos que dela derivam, como o fato de a poesia ser uma linguagem constituída por meio de um ato consciente do poeta e que por isso é perene e se eterniza.

Essa concepção de poesia apresenta-se em Hilst como ponto fundante e fundamental de sua lírica, no que se refere à voz que se reveste de um personagem e canta para um público também fictício. Nessa relação, o eu lírico, Ariana, coloca-se na posição de "senhora" da situação, porque o poeta não quer a brevidade das coisas, mas a eternidade: "Ariana e Catulo luxuriantes / Pretendem eternidade, e a coisa breve /A alma dos poetas não inflama". Dessa forma, vemos que a relação interlocutiva, no plano da construção poética, vai além de uma tentativa de diálogo com Dionísio na figura do amado. Há no poema, certo desprezo por Dionísio, pois este mostra ser volúvel no plano da relação amorosa. Para Ariana, os "amores breves" nada significam, pois o que importa para ela é a poesia: "A alma dos poetas não inflama”.

A proposta feita pela voz lírica de Hilst instaura-se na tensão entre lição de poesia e lição de amor. Nessa relação Ariana coloca Dionísio sob suas teias, movida pelo desejo de desejá-lo em ausência. Por isso trabalha com a perspectiva de uma falsa realidade em que a presença de Dionísio é o gozo de sua poesia: "Se todas as tuas noites 
fossem minhas" e "E agudo se faria o gozo teu". Vejamos, nesta última parte da Ode, como isso se constitui:

\title{
$\mathrm{X}$
}

\author{
Se todas as tuas noites fossem minhas \\ Eu te daria, Dionísio, a cada dia \\ Uma pequena caixa de palavras \\ Coisa que me foi dada sigilosa \\ E com a dádiva nas mãos tu poderias \\ Compor incendiado a tua canção \\ E fazer de mim mesma, melodia. \\ Se todos os teus dias fossem meus \\ Eu te daria, Dionísio, a cada noite \\ O meu tempo lunar, transfigurado e rubro \\ E agudo se faria o gozo teu.
}

(HILST, 2003, p. 68)

Esta última parte da Ode encena tanto à forma quanto ao conteúdo a sua lírica da ausência, que encaminha para a reflexão sobre o ato de criação poética. $\mathrm{O}$ eu lírico detém o poder da palavra e quer fisgar o seu interlocutor pela habilidade e pela dádiva de manusear as palavras. A "pequena caixa de palavras", que poderia ficar nas mãos de Dionísio, caso este estivesse presente. Ariana coloca-se como peça fundamental de inspiração de Dionísio. Isso demonstra, mais uma vez, a superioridade de Ariana sobre Dionísio. Uma voz centrada em si que busca, na interlocução com seu público, no caso, Dionísio, exercer domínio sobre ele, e fazendo com que o dito incida na forma de dizer. Hilda Hilst se achava temerosa em relação a sua obra, porque não era lida do modo que desejava. Havia uma preocupação internalizada em seu discurso a respeito disso que acabava se transformando em poesia, porque a poesia é feita de conexões com seu público. A experiência com o público, no processo criativo é, também, uma experiência das próprias desilusões da poeta frente ao vivido, o que não deixa de ser uma experiência interlocutiva. Marcos Siscar, ao tratar da relação entre poesia e público, afirma que "a obra se comunica com seu público, menos pela transmissão de conteúdos informacionais 
do que pela capacidade que tem de devolver a esse público a imagem daquilo que é (ou poderia ser) sua própria experiência (vivida ou imaginada) dos desequilíbrios do mundo". (2010, p. 36). Desta forma, a poesia precisa achar um lugar em que se conecte com o público, porque não há poesia que não seja afetada por ele.

Retomamos agora os versos da epígrafe deste capítulo, que nos levam para a compreensão da poesia de Hilst nesta seção do livro Júbilo, memória, noviciado da paixão. Ela é constituída e vive através de um interlocutor: “A ideia, Túlio, [...] /Vive através de Ti, por isso brilha". Hilst cria um personagem e fala pela voz dele a um público também fictício, Dionísio, entretanto, também fala para si porque prefere Dionísio em ausência, por isso, não importa a comunicação entre o eu lírico e o seu interlocutor criado. Logo, é possível ver neste livro, as várias vozes em fluxo contínuo que, aos moldes de Eliot, apresentam-se em Hilst. 


\section{CONSIDERAÇÕES FINAIS}

Falar sobre lírica exige um olhar analítico que seja capaz, a um só tempo, de se orientar por múltiplos percursos, sejam eles históricos ou não. É também assumir os riscos do diálogo com teorias que foram criadas e retomadas através dos tempos, e, mais ainda, das dificuldades de reflexão acerca da obra de uma poeta singular no trato com a criação, como Hilda Hilst. A leitura de sua lírica, delineada nos livros selecionados para esta pesquisa, mostra-nos o seu modo de inscrição interlocutiva e sua inserção no panorama das discussões sobre a lírica na trajetória de sua obra.

Entre os aspectos que estruturam a constituição da poesia de Hilst, o processo interlocutivo é um elemento catalisador, porque sua lírica nele se desencadeia e a partir dele a concepção de eu lírico e sua relação com o interlocutor é colocada de forma contundente e, ao mesmo tempo, problemática. Por intermédio desse processo de interlocução é possível pensar em alguns tipos de concepções sobre a lírica: na poesia moderna, o eu lírico se transforma em sujeito; exige-se, ao mesmo tempo, a participação de um interlocutor, visando estabelecer relações para que a obra seja realizada. Essa configuração se avizinha com o lugar que a poesia moderna ocupa, ou seja, a consciência representada pela linguagem do poeta. E na concepção moderna de poesia, na qual o jogo entre lírica e antilírica, poeta e receptor, arte e vida, entre outros, estabelece-se um jogo de tensões.

A modernidade, da segunda metade do século XIX à primeira metade do século $\mathrm{XX}$, legou para o tempo presente um sujeito lírico que se constitui na relação de alteridade, instaurando a lírica como espaço de redefinição do eu. Essa "saída do prumo" do eu desestabiliza a expressão de subjetividade e faz com que ele acabe perdendo a soberania e se realize no outro de maneira a provocar tensão entre as instâncias do "eu" 
lírico e o "sujeito" lírico moderno. Um outro tipo de tensão está entre a constituição do sujeito e a estrutura da poesia moderna, que se faz pelo raciocínio, emoção e persuasão. Levando em consideração esses três aspectos, podemos corroborar a afirmação de que a lírica da modernidade, "não é uma coisa dita, mas um modo de dizê-la. Pode ela, pois, ser isolada e estudada por si mesma? Porque a combinação da linguagem com seu conteúdo intelectual, seu sentido, é uma união tão estreita quanto se possa imaginar." (Housman, apud HAMBURGER, 2007, p. 37).

Em Hilst, o sentido de emoção na poesia é uma emoção "fora de si”, realizada no outro. Por isso, sua poesia convive com a lírica da modernidade, porque recusa o lirismo puro como única expressão do eu. Ocorre uma espécie de dessubjetivação do sujeito e encena-se outra roupagem para si: este sujeito define-se pelo outro. Assim, em Hilst, a expressão de subjetividade se desinterioriza e busca, em seu processo de criação, endereço no amado, em Deus e/ou na obra. E isso é muito bem arquitetado pela poeta, quando projeta um eu lírico que finge desapossar-se de si para cantar o amor e a própria poesia.

Nessa relação, até certo ponto conflituosa, Hilst cria, por meio de seu canto, um eu que performatiza um interlocutor e tematiza o que Celia Pedrosa chama de endereçamento. Desse conceito referenda-se ao poeta uma "distensão identitária do eu e, analogamente, da destinação de seu discurso, associado às problematizações da subjetividade e às transformações na relação entre literatura e público, ambas características da modernidade”. (PEDROSA, 2014, p. 70).

Essa forma de lírica remete à reflexão sobre um campo de junção entre lírica e modernidade, como sugere Emil Staiger, em que esta é vista como recordação, canto, permeado por uma disposição anímica interiorizada e em profundidade de um eu que externa sua sentimentalidade. A lírica assim proposta pode incorrer no risco de ser apenas 
expressão individualizada do "eu”. O sentimento contido em um discurso poético é expresso no momento em que é exteriorizado para um público que o atualizará no momento da leitura; não se caracteriza unicamente pelo estado estático de um “eu”, e sim por uma interlocução deste "eu" com um "você". Assim, as emoções, em Hilst, expressam-se pela forma de comunicação com o outro, e só existem pela exteriorização do discurso.

O trabalho da poeta é depurar as emoções de forma que não se tornem apenas expressões individualizadas. É assim que a crítica de poesia hoje, comumente, a vê. A respeito disso, segundo Celia Pedrosa ${ }^{78}$, “poesia, hoje, não é um mergulho nas profundidades do eu e, por conseguinte, não se encerra em um discurso individualista, solipsista, voltado para um ato solitário do eu e suas sensações". A experiência de um sujeito preso em si infere, na lírica de Hilst, um pensamento no mínimo perturbador em relação ao seu modo de inserção no seu tempo e no seu espaço.

Utilizando a metáfora do "confim" da poesia, mencionada por Scramin, (2007, p. 63), como um lugar onde um espaço toca o outro, o lugar da lírica de Hilst e sua relação com a constituição do eu lírico se define quando toca o outro, isto é, quando se realiza no outro, quando clama o outro como interlocutor, ao mesmo tempo em que o despreza. E esse é o lugar do desejo do qual tudo emana. É preciso seduzir o outro com formas e palavras para criar um jogo de sedução configurado pelo desejo e, o lugar e o tempo do desejo é o agora, por isso a sua voz canta sempre no presente. Nesse sentido, sua poesia instaura a consciência do presente pelo ato de desejar.

Os livros de Hilst trabalhados neste estudo produzem também, pelo seu discurso, uma reflexão sobre o diálogo com o passado e a aceitação do presente que não se projeta

\footnotetext{
78 Em conferência proferida em 31/01/2014, na Universidade Federal de Rondônia - UNIR, Campus de Vilhena, na qual a conferencista tratou do conceito de endereçamento na poesia brasileira contemporânea.
} 
no futuro, mas busca a afirmação do momento em que se realiza na presença/ausência de um interlocutor. Aponta para essa diluição de fronteiras acerca da lírica tradicional e sua consciência criativa revela a extensão de seu tempo. Por isso, quando usa tons e formas poéticas já visitadas pela tradição, a poeta nos dá indícios de que esses recursos são utilizados para recuperar sentidos para sua poética, mas não de forma irônica ou crítica. Na relação com outras formas, tempos e espaços, a sua poética passa a ser o "novo" sendo o "mesmo".

Podemos dizer que refletir sobre a poesia de Hilda Hilst pressupõe pensá-la não como reflexo de si mesma, mas sempre em tensão com lugares, tempos e vozes diversos que compõem o seu discurso. E isto a torna uma poeta anacrônica. Dizendo de outro modo, a noção de subjetividade lírica do sujeito atua em consonância anacrônica com outros tempos e outros espaços. A identificação da poesia como canto "Meu canto compassado / de mulher-trovador" (HILST, H. 2004, p. 59) é uma maneira de legitimar essa lírica e ver o texto poético como objeto de compreensão lírica através dos tempos.

A postura criativa de Hilst endossa a necessidade de revisitar as formas poemáticas como modo de mobilizá-las ao seu favor e para se valer delas como uma poeta que tem capacidade de criação. Ao revisitar as formas das odes e baladas, cantos e elegias, não as problematiza de forma crítica como fizeram os modernos. Ao nível formal, Hilst faz a recuperação das formas que problematiza, porque sua poesia oscila por vários tempos e espaços. Por essa capacidade a que se submete sua a poesia, vemos um teor extemporâneo, termo usado por G. Agamben, para o qual pertencer ao seu tempo significa não se adequar totalmente a este. O tempo contemporâneo é, segundo o autor, "uma relação singular com o próprio tempo, que adere a este e, ao mesmo tempo, dele toma distâncias, essa é a relação com o tempo que a este adere através de uma dissociação e 
um anacronismo". ( 2009, p.59). Pensando desse modo, é possível dizer que a poesia de Hilst tem um pé na contemporaneidade.

Ao analisar a obra de Hilst sob o ponto de vista dessas tensões, a relação nada amistosa entre a linguagem e o mundo, entre o eu e o outro ficcionalizado, presente nos livros de poemas aqui dispostos, foi possível perceber que a poeta constitui uma forma diferente de concepção do eu lírico. Este está "em si” e, ao mesmo tempo, é um eu inquieto, porque precisa do outro, não para se afirmar, mas para dominá-lo. É uma voz que se faz por meio de um jogo camaleônico e simultâneo que encena a figura de "mulher fatal" e ao mesmo tempo "abandonada" pelo amado, pois em um de seus versos ela diz: “Apenas tu Dionísio é que recusas /Ariana suspensa nas tuas águas” (Ode descontínua e remota para flauta e oboé: De Ariana para Dionísio, p.67). Desta forma, o eu lírico se configura como uma espécie de sereia que emerge da água e, com seu canto, atrai o interlocutor e o tem sob seu domínio.

Neste universo encontra-se a poesia de Hilda Hilst: no "entre" que determina uma dinâmica entre realidade e criação, que se figura ou se atualiza na tensão representacional. Estudar a obra desta escritora pelo viés da poesia permitiu refletir sobre a sua escrita, que se faz de grande apuro técnico e relevantes discussões filosóficas em linguagem obscura, “obscena” e até insólita, contida numa densidade subjetiva, fato que torna sua leitura nada amena, mas não menos estimulante. Acrescentamos a isso o aumento de interesse da crítica pela sua obra, mesmo que esta ressinta, ainda, de uma crítica acadêmica mais abundante. 


\section{REFERÊNCIAS BIBLIOGRÁFICAS}

1. Obras da autora:

HISLT, Hilda. Amavisse. São Paulo: Massao Ohno, 1989.

A Obscena Senhora D. São Paulo: Globo, 2001.

. Baladas. São Paulo: Globo, 2003.

. Bufólicas. São Paulo: Globo, 2002.

. Cantares. São Paulo: Globo, 2004.

. Cantares de perda e predileção. São Paulo: Massao Ohno, 1983.

. Cantares do sem nome e de partidas. São Paulo: Massao Ohno, 1995.

. Cascos e Carícias e outras crônicas. São Paulo: Globo, 2006.

. Com meus olhos de cão. São Paulo: Globo, 2006.

. Contos d'scárnio, textos grotescos. São Paulo: Globo, 2012.

. Da morte. Odes Mínimas. São Paulo: Globo, 2003.

. Do desejo. São Paulo: Globo, 2004.

. Do desejo. Campinas: Pontes, 1992.

. Estar sendo. Ter sido. São Paulo: Nankin Editorial, 1997.

. Exercícios. São Paulo: globo, 2002.

Fluxo-Floema. São Paulo: Globo, 2003.

Fluxo-Floema. São Paulo: Perspectiva, 1970.

Júbilo, memória, noviciado da paixão. São Paulo: Globo, 2003.

.Júbilo, memória, noviciado da paixão. S. Paulo: Massao Ohno, 1974.

. Kadosh. São Paulo: Globo, 2002.

. O caderno rosa de Lori Lamby. S. Paulo: Massao Ohno Editor, 1990.

. Poemas malditos, gozosos e devotos. São Paulo: Globo, 2005.

Poesia (1959-1967) São Paulo: Luzes -Gráfica Editora Ltda, s/d.

. Roteiro do silêncio. São Paulo: Anhambi, 1959.

. Rútilos. São Paulo: Globo, 2003.

Rútilo nada. São Paulo: Globo, 2003.

Teatro Completo. Posfácio Renata Pallottini. São Paulo: Globo, 2008.

.Tu não te moves de ti. São Paulo: Globo, 2004. 


\section{Textos críticos sobre a autora:}

ALMEIDA, Gerusa Z. A geometria do pensar na poesia de Hilda Hilst. Terra roxa e outras terras - Revista de Estudos Literários. Volume 11 (2007) -. ISSN 1678-2054 http://www.uel.br/cch/pos/letras/terraroxa. Acesso em 10/11/10.

BARROS, Luisa da Rocha; BORGES, Julia. Temas e figuras em "Bufólicas". Estudos Semióticos, Número 2, São Paulo, 2006.

Disponível em www.fflch.usp.br/dl/semiotica/es. Acesso em 14/03/2014.

BRANCO, Lucia Castello. A(im)possibilidade da escrita feminina. In: A mulher escrita. Rio de Janeiro: Casa Maria/TLC Livros Técnicos Científicos, 1989.

CADERNOS DE LITERATURA BRASILEIRA: HILDA HILST. São Paulo: Instituto Moreira Salles. N. 8, out. 1999.

CASTELO, José. A maldição de Potlatch. In: Inventário das sombras. $3^{\mathrm{a}}$ ed. Rio de Janeiro: Record, 2006.

. Hilda Hilst: entre o eterno e o efêmero. O Estado de S. Paulo: São Paulo. 20 de março de 1983.

CINTRA, Elaine Cristina. FREITAS e SOUZA, Enivalda Nunes. (Orgs) Roteiro Poético de Hilda Hilst. Uberlândia: EDUFU, 2009.

COELHO, Nely Novaes. Da poesia. $\mathrm{CBL}^{\circ}{ }^{\circ}$. São Paulo: Instituto Moreira Salles, out. 1999.

COLI, Jorge. Meditações em imagens. Discurso Editorial/ USP/FOLHA DE SÃO PAULO, Sexta feira, 14 d de junho de 1996, Jornal de Resenhas - Especial, p.5

CUNHA, Rubem da. O fracasso na escrita de Hilda Hilst. Revista Landa, n.0, 2012. Disponível em:

http://www.revistalanda.ufsc.br/PDFs/Rubens\%20da\%20Cunha\%20$\% 200 \% 20$ FRACASSO $\% 20$ NA\%20ESCRITA $\% 20$ DE $\% 20$ HILDA $\% 20$ HILST_landa_0 .pdf. Acesso em 27/03/14.

DESTRI, Luisa. A Língua Pulsante de Lory Lamby. In: MIRANDA, Adelaide C. de. (et al.). Protocolos críticos. São Paulo: Iluminuras: Itaú Cultural, 2008.

De tua sábia ausência: a poesia de Hilda Hilst e a tradição lírica amorosa. Dissertação de mestrado. IEL-Unicamp. Campinas, 2010.

Globo, 2012.

. Uma superfície ancorada no riso/antologia de Hilda Hilst. São Paulo:

DINIS, Cristiano. (org.) Fico besta quando me entendem. Entrevistas com Hilda Hilst.

São Paulo: Globo, 2013. 
DIAS, Juarez Guimarães. O fluxo metanarrativo de Hilda Hilst em Fluxo-floema. São Paulo: Annablume, 2010.

DUARTE, Edson Costa. "A poesia amorosa de Hilda Hilst". In: HILST, Hilda. Do amor. São Paulo, Edith Arnhold/Massao Ohno, 1999, p.89-95.

Cantares do sem Nome e de Partidas: dos Afetos ao Excesso. Revista Rascunhos Culturais, Coxim/MS, vol.2, n.4, p.171-194. Jul/dez de 2011.

GRAIEB, Carlos. Hilda Hilst expõe roteiro do amor sonhado. O Estado de S. Paulo, São Paulo, 14 ago. de 1995. (Entrevista).

LEAL, Isabela. A metafísica obscena de Hilda Hilst. In: GUIMARÃES, Mayara (org). No meio-dia verde do agora. Rio de Janeiro, Oficina Raquel, 2012.

MOURA, Karyni Pimenta de Moura. Hilda Hilst e o canto da Mulher Selvagem: um olhar pela Crítica do Imaginário. $O$ texto está disponível em: http://www2.assis.unesp.br/cilbelc/jornal/julho08/content12.html

OLIVEIRA, Luiz Roberto P. Furtado de. Memória - A Deiscência da Percepção. FólioRevista de Letras. Vitória da Conquista v. 5, n. 1 p. 63-80 jan./jun. 2013. Disponível em http://periodicos.uesb.br/index.php/folio/article/view/1873. Acesso em 23/09/2015.

PALLOTTINI, Renata. Posfácio. In: Teatro completo. São Paulo: Globo, 2008.

PÉCORA, Alcir. Nota do Organizador. In: HILST, Hilda. A obscena Senhora D. São Paulo: Globo, 2001.

. Nota do Organizador. In: HILST, Hilda. Baladas. São Paulo: Globo, 2004.

. Nota do Organizador. In: HILST, Hilda. Cantares. São Paulo: Globo, 2004.

. Nota do Organizador. In: HILST, Hilda. Cascos e carícias e outra crônicas. São Paulo: Globo, 2006 Globo, 2006.

Nota do Organizador. In: HILST, Hilda. Com meus olhos de cão. São Paulo:

. Nota do Organizador. In: HILST, Hilda. Contos d'scárnio. São Paulo: Globo, 2012. Globo, 2003.

Nota do Organizador. In: HILST, Hilda. Da morte, odes mínimas. São Paulo: . Nota do Organizador. In: HILST, Hilda. Do desejo. São Paulo: Globo, 2004. . Nota do Organizador. In: HILST, Hilda. Exercícios. São Paulo: Globo, 2002. . Nota do Organizador. In: HILST, Hilda. Fluxo-floema São Paulo: Globo, 2003. 
Nota do Organizador. In: HILST, Hilda. Júbilo, memória e noviciado da paixão. São Paulo: Globo, 2003.

. Nota do Organizador. In: HILST, Hilda. Kadosh. São Paulo: Globo, 2002.

- Nota do Organizador. In: HILST, Hilda. Poemas malditos, gozosos e devotos. São Paulo: Globo, 2005.

. Nota do Organizador. In: HILST, Hilda. Rútilos. São Paulo: Globo, 2003.

2008.

. Nota do Organizador. In: HILST, Hilda. Teatro completo. São Paulo: Globo, Globo, 2004.

Nota do Organizador. In: HILST, Hilda. Tu não te moves de ti. São Paulo: O corpo do texto. Ensaio originalmente publicado em Reportagem, $n^{\boldsymbol{o}} 29$, jan.

2002. Disponível em: http://www.oficinainforma.com.br/semana/leituras2002/0413/03.htm. - Acesso em 28 de setembro de 2008.

(org.) Por que ler Hilda Hilst. São Paulo: Globo, 2010.

QUEIROZ, Vera. Hilda Hilst: três leituras. Florianópolis: mulheres, 2000.

Hilda Hilst e a arquitetura de escombros. Ipotesi (UFJF) Editora UFJF Juiz de Fora, v. 8, n.1, p.67-78, 2004.

REGUERA, Nilze Maria Azeredo. Hilda Hilst e o seu pendulear. São Paulo: Unesp, 2013.

ROSENFELD, Anatol. Hilda Hilst: poeta, narradora, dramaturga. In: HILST, Hilda. Fluxo-floema. São Paulo: Perspectiva, 1970.

SALGUEIRO, Wilberth C. Ferreira. Uma certa enciclopédia poética. Cismas em torno da poesia brasileira pós-80. Ipotese: Rev.de Estudos Literários de Juiz de Fora. Vol. 5, n.2. p.99 a 116. Disponível em: httpwww.ufjf.brrevistaipotesifiles200912Uma-certaenciclopedia1.pdf.

SILVA, Frederico Spada. Os cantares do amor: A lírica amorosa na poesia de Hilda Hilst. Darandina Revista Eletrônica. - http://www.ufjf.br/darandina/. Anais do Simpósio Internacional Literatura, Crítica, Cultura VI - Universidade Federal de Juiz de Fora.

SILVA, Leandro Soares. Esperando Deus: a prosa de Hilda Hilst e os silêncios da divindade. Revista da UEFS - Cadernos de Literatura e Diversidade. p.67 a 87. Disponível em http://www2.uefs.br/ppgldc/publicacoes/cad.lit.div.n6_067-087.pdf

SILVA, Vera Maria T._Cantares de encontros, partidas e contradições (uma leitura de Cantares, de Hilda Hilst). In: CINTRA, Elaine Cristina. FREITAS e SOUZA, Enivalda Nunes. (Orgs) Roteiro Poético de Hilda Hilst. Uberlândia: EDUFU, 2009. 
SOBRINHO, Arnaldo Delgado. Chamamentos a um amigo: a reescrita da lírica amorosa nas poéticas de Hilda Hilst e Eugênio Andrade. 2011, 145 p. Dissertação (Mestrado em Teoria Literária e Literatura Comparada). Faculdade de Filosofia, Letras e Ciências Humanas - USP, São Paulo, 2011.

SOUZA, Enivalda Nunes Freitas. A genealogia do amor em Hilda Hilst. Revista Texto Poético, GT Teoria do Texto Poético. Vol. 6., 2009. Disponível em http://www.textopoetico.com.br/index.php?option=com_content\&view=article\&id=13 \&Itemid=2. Data de acesso: 20/03/14.

WILLER, Claudio. Amavisse, de Hilda Hilst: pacto com o hermético. Revista de Cultura, 43, São Paulo: 2005.

3. $\quad$ Obras traduzidas de Hilda Hilst

Para o francês:

L'obscène madame D suivi de le chien. Tradução de Maryvonne Lapouge-Pettorelli. Paris, Gallimard, 1997.

Contes sarcastiques - fragments érotiques. Tradução de Maryvonne Lapouge-Pettorelli. Paris, Gallimard, 1994.

Agda (fragmento). Brasileiras. Organização de Clélia Pisa \& Maryvonne-Lapouge Petorelli. Paris, França, 1977.

- Sobre a Tua Grande Face. Tradução de Michel Riaudel. Revista Pleine Marge, 2o semestre de 1997, Paris.

Da morte. Odes mínimas/ De la mort. Odes minimes. Edição bilingüe. Tradução de Álvaro Faleiros. Ilustrações de Hilda Hilst. São Paulo, Nankin Editorial/Montreal-Noroît, 1998.

Para o italiano:

Il quaderno rosa di Lori Lamby. Tradução de Adelina Aletti. Milano, Sonzogno, 1992.

Para o Espanhol:

Rútilo Nada. In Revista literária De Azur, Columbia University Station, New York, verano 1994. (Tradução para o espanhol de Liza Sabater), pp 49-59.

Para o inglês: 
“Glittering Nothing”. In FERREIRA-PINTO, Cristina (Edited, with an Introduction and Notes). Tradução de David Willian Foster Urban Voices - Contemporary Short Stories from Brazil. New York, University Press of America. Inc., 1999. pp. 20-32.

“Two Poems". Tradução de Eloah F. Giacomelli. InThe Antigonish Review, no 20. St. Francis Xavier University, Nova Scotia, Canadá, 1975. p 61.

\section{Para o alemão:}

Briefe eines Verführers. (Cartas de um Sedutor, fragmento.). Tradução de Mechthild Blumberg. In "Stint. Zeitschrift für Literatur", n² 27, ano 15, Bremen, outubro 2001, pp.2830 .

Funkelndes Nichts. (Rútilo Nada). Tradução de Mechthild Blumberg. In "Stint. Zeitschrift für Literatur", n 29, ano 15, Bremen, agosto 2001, pp.54-66.

Vom Tod. Minimale Oden. (Da Morte. Odes Mínimas.). (Odes I, IV, V, VI, VIII, XII, XIX e poemas I e III de "Á tua frente. Em vaidade"). Tradução de Curt Meyer-Clason. In Modernismo Brasileiro und die brasilianische Lyrik der Gegenwart. Berlin, 1997.

\section{Textos teóricos e críticos}

ACHCAR, Francisco. Lírica e lugar-comum. São Paulo: Edusp, Editora da Universidade de São Paulo, 1994.

AGAMBEN, Georgio O que é o contemporâneo? In: O que é o contemporâneo? E outros ensaios. Trad. Vinicius N. Honesko. Chapecó, SC: Argos, 2009.

ARISTÓTELES. Arte Poética. Versão digital, Domínio Público: file://C//site/livros_gratis/arte_poetica.htm (1 of 53) [3/9/2001 15:05:19]

BARBOSA, As ilusões da modernidade. São Paulo: Perspectiva, 2009.

BARTHES, Roland. Crítica e Verdade. Trad. Leyla Perrone-Moisés. São Paulo: Perspectiva, 1999. 2004.

O rumor da língua. Trad. Mario Laranjeira. 2 ed. São Paulo: Martins Fontes.

BAUDELAIRE, Charles. Meu coração desnudado. Trad. E notas: Tomaz Tadeu. Belo Horizonte: Autêntica Editora, 2009. 
O pintor da vida moderna. Trad. Tomaz Tadeu. Concepção e organização Jerôme Dufilho e Tomaz Tadeu. Belo Horizonte: Autêntica, 2010.

BECKER, Ernest. A negação da morte. Trad. Luiz Carlos do Nascimento e Silva. Rio de Janeiro: Record, 2013.

BENJAMIN. W. Charles Baudelaire: um lírico no auge do capitalismo. Trad. José Martins Barbosa, Hemerson Alves Baptista. 1a ed. São Paulo: Brasiliense, 1994.

Sobre o conceito de história. In: Magia e técnica, arte e política. Trad. Sergio Paulo Rouanet. $7^{\mathrm{a}}$ ed. São Paulo: Brasiliense, 1994.

. Charles Baudelaire: um lírico no auge do capitalismo. Trad. José Martins Barbosa, Hemerson Alves Baptista. 1ª ed. São Paulo: Brasiliense, 1994.

. Origem do drama trágico alemão. Edição e tradução João Barreto. Belo Horizonte: Autêntica Editora, 2011.

BENVENISTE, Émile. Da subjetividade na linguagem. In: Problemas da linguística geral. Trad. Maria da Glória Novak e Luíza Neri. Revisão: Isaac Nicolau Salum. São Paulo: Ed. Nacional, Ed. Da Universidade de São Paulo, 1976.

BERARDINELLI, Alfonso. Da poesia à prosa. Organização e Prefácio Maria Betânia Amoroso, Tradução: Maurício Santana Dias. São Paulo: Cosacnaify, s/d.

BÍBLIA SAGRADA. Cântico dos cânticos de Salomão. 55 a ed. Trad. Por monges de Maredsous da Bélgica - Centro Bíblico Católico São Paulo: Edições Ave Maria Ltda. 1957.

BORNHEIM, Gerd. Da superação à necessidade: o desejo em Hegel e Marx. In: NOVAES, Adauto.(org.) O Desejo. São Paulo: Companhia das Letras; Rio de Janeiro: Funarte, 1990.

BORGES, Jorge Luis. Esse ofício do verso. São Paulo: Companhia das Letras, 2000.

BOSI, Alfredo. O ser e o tempo da poesia. São Paulo: Cultrix, 1983.

CAMARGO, Maria Lúcia de Barros e PEDROSA, Celia. Poesia e contemporaneidade - leituras do presente. (orgs) Chapecó: Argos, 2001.

CAMPOS, Haroldo de. A arte no horizonte do provável. São Paulo: Perspectiva, 1977.

CEIA, Carlos. Dicionário de termos literários. Disponível em: http://www.edtl.com.pt/index.php?option=com_mtree\&task=viewlink\&link $\mathrm{id}=944 \& \mathrm{It}$ emid=2.

CHAUÍ, Marilena. Laços do desejo. In: NOVAES, Adauto. (Org.) O Desejo. São Paulo: Companhia das Letras; Rio de Janeiro: Funarte, 1990.

SCHEEL, Márcio. A literatura aos pedaços: a fragmentação discursiva e a problemática da representação do primeiro romantismo alemão à modernidade $e$ 
ao pós-modernismo. 393 f. Tese (Doutorado em Letras). Faculdade de Ciências e Letras da Universidade Estadual Paulista, Campus de Araraquara. Área de Concentração: Estudos Literários, 2009.

CHEVALIER, J.; GHEERBRANT, A. Dicionario de los símbolos. Barcelona: Editorial Herder, 1986.

COLLOT, Michel. O sujeito lírico fora de si. Trad. Alberto Pucheu. Terceira Margem: Revista do Programa de Pós-Graduação em Ciência da Literatura. Universidade Federal do Rio de Janeiro, Centro de Letras e Artes, Faculdade de Letras, Pós-Graduação, Ano IX, no 11, 2004. (p. 164 a 176).

COMPAGnON, Antonie. O Demônio da Teoria. Literatura e Senso Comum. Trad. de Cleonice P. B. Mourão e Consuelo F. Santiago. Belo Horizonte: Ed. UFMG, 2001.

Os cinco paradoxos da modernidade. Trad. de Cleonice P. B. Mourão, Consuelo F. Santiago e Eunice Galery. Belo Horizonte: Ed. UFMG, 1996.

CONNOR, Steven. Cultura Pós-moderna. Introdução às teorias do contemporâneo. 4 ed. São Paulo: Loyola, 2000.

COSTA LIMA, L. “A questão dos gêneros.” In: Teoria da literatura e suas fontes, Vol. 1. Rio de Janeiro: Francisco Alves, 1983.

CRUZ, Edson.(org.) O que é poesia? Rio de Janeiro: Confraria do Vento: Calibán, 2009.

DIAS, G. Poesia e prosa completas. Rio de Janeiro: Aguilar, 1998.

D’ONÓFRIO, Salvatore. Teoria do texto 2: Teoria da lírica e do drama. São Paulo: Ática, 1995.

1983.

Teoria da literatura. Trad. Waltensir Dutra. São Paulo. Martins Fontes.

ELIOT, T. S. A essência da poesia. Trad. Maria Luiza Nogueira. Rio de Janeiro: Editora Arte Nova S.A., 1972.

Art. Editora. 1989.

FAVARETO, Celso. Do horror: a cena contemporânea. In: Teresa Revista de Literatura Brasileira 10/11 (2009-2010). São Paulo: Ed. 34. 2010.

FRIEDRICH, Hugo. Estrutura de Lírica Moderna. Trad. Marise M Curione. São Paulo: Duas Cidades, 1978.

GAGNEBIN, Jeanne Marie. Walter Benjamin ou a história aberta (Prefácio). In: Walter Benjamin (Obras Escolhidas). Magia e Técnica, Arte e Política (v. 1).5. ed. São Paulo: Brasiliense, 1993. 
GARRAMUÑO, Florencia. A experiência opaca: literatura e desencanto. Trad. Paloma Vidal. Rio de Janeiro: EdUERJ, 2012.

GOLDSTEIN, Norma. Versos, sons, ritmos. 10ª ed. São Paulo: Ática, 1998.

GRANDO, Diego. Mais eus do que eu: sujeito lírico, alteridade, multiplicidade. Dissertação de mestrado. Biblioteca Central Irmão José Otão - Pontifícia Universidade Católica do Rio Grande do Sul, Porto Alegre, 2008.

HAMBURGER, Käte. A lógica da criação literária. Trad. Margot P. Malnic. 2 ed. São Paulo: Perspectiva, 2013.

HAMBURGUER, Michel. A verdade da poesia. Trad. Alípio Correia de Franca Neto. São Paulo: Cosac Naify, 2007.

HEGEL, George W. Friedrich. Curso de Estética, vol. IV. Tradução Marco Aurélio Werle, Oliver Tolle, Consultoria Victor Knoll. São Paulo: Editora da Universidade de São Paulo, 2004. ( Clássicos; 26).

HOLLANDA, Heloísa Buarque de. Esses poetas uma antologia dos anos 90. 2 ed. Rio de Janeiro: Aeroplano Editora, 2004.

LYOTARD, Jean-François. O pós-moderno. Trad. R. C. Barbosa. 3. ed. Rio de Janeiro: José Olympio, 1988.

MAleval. Maria do Amparo Tavares. Poesia medieval no Brasil. Rio de Janeiro: Ágora da Ilha, 2002.

MORICONI, Ítalo. Pós-modernismo e volta do sublime na poesia brasileira. In: Poesia Hoje. Org: Célia Pedrosa, Claudia Matos e Evandro Nascimento. Niterói: EdUFF.

MARTINS, Nilce Sant'Anna. Introdução à estilística. São Paulo: T.A.Queiroz: Editora da Universidade de São Paulo, 1989.

NOVAES, Adauto. O fogo escondido. In: NOVAES, Adauto. (org.) O Desejo. São Paulo: Companhia das Letras; Rio de Janeiro: Funarte, 1990

PAZ, Octávio. O arco e a lira. Trad. Ari Roitman e Paulina Wacht. São Paulo: Cosac Naify, 2012.

Os filhos do barro: do romantismo à vanguarda. Trad. Ari Roitman e Paulina Wacht. São Paulo: Cosac Naify, 2013.

PEDROSA, Célia. ALVES, Ida. (Orgs) Subjetividades em devir. Estudo de poesia moderna e contemporânea. Rio de Janeiro: 7Letras, 2008.

Poesia, crítica e endereçamento. In: KIFFER, Ana; GARRAMÛNO, Florência. (Orgs.). Expansões contemporâneas. Literatura e outras formas. Rio de Janeiro: EdUFMG, 2014. p. 69-89. 
PERRONE-MOISÉS. Leyla. A modernidade em ruínas. In: Altas literaturas: escolha e valor na obra crítica de escritores modernos. São Paulo: Companhia das Letras, 1998.

Falência da Crítica. Perspectiva. São Paulo, 1973.

PESSANHA, José Américo Motta. A água e o mel. In: NOVAES, Adauto.(org.) O Desejo. São Paulo: Companhia das Letras; Rio de Janeiro: Funarte, 1990.

PIERUCCI, Antônio Flávio. O desencantamento do mundo: todos os passos do conceito em Marx Weber. $3^{\text {a }}$ ed. São Paulo: Editora 34, 2013.

PIGNATARI, Décio. O que é comunicação poética. Cotia: Ateliê Editorial, 2005.

PINTO, Manuel da Costa. Literatura brasileira hoje. São Paulo: Publifolha, 2004.

POE, Edgar Allan. Ficção completa, poesia \& ensaios. Rio de Janeiro: Nova Aguilar S.A., 2001.

SÁ, O. BECKER, N. C. Res Amissa e o ter-lugar da linguagem. FronteriaZ-Rev. Digital do Programa de Estudos Pós-graduados em Literatura e Crítica Literária. $\mathrm{N}^{\mathrm{o}} 10$, jun/ 2013.

Disponível em revistas.pucsp.br/index.php/fronteiraz/article/download/14742/11799. Acesso em 13/08/2014.

SARTRE. Jean Paul. Que é a literatura? São Paulo: Ática, 1999.

SANT'ANNA, Affonso Romano. O pensamento crítico de T.S. Eliot. In: ELIOT, T. S. A essência da poesia. Trad. Maria Luiza Nogueira. Rio de Janeiro: Editora Arte Nova S.A., 1972.

SANTOS, Laymert Garcia. Lautréamont e o desejo de não desejar. In: NOVAES, Adauto. (org.) O Desejo. São Paulo: Companhia das Letras; Rio de Janeiro: Funarte, 1990.

SCRAMIM, Susana. Literatura do presente. Chapecó: Argos, 2007.

SISCAR, Marcos. Ana Cristina César. Rio de Janeiro: EdUERJ, 2011. (Coleção Ciranda da Poesia.).

. Entrevista à Revista Alea, por Masé Lemos- (on-line). 2011, vol.13, n. 1, pp.168-182, ISSN 1517.

Imposturas de Charles Baudelaire: Paixão poesia e cultura nos

intimes. In: PIRES Antônio Donizeti e FERNANDES, Maria Lúcia Outeiro (Orgs.). Matéria de Poesia: crítica e criação. Araraquara: FCL-UNESP Laboratório Editorial; São Paulo: Cultura Acadêmica, 2010.

Poesia e crise. Campinas, SP: Editora Unicamp, 2010. 
.Tomar pé. [Texto apresentado no seminário "Poesia Brasileira 1980-2010: Processos e Percursos", organizado na PUC-Rio, 2010, por Paulo H. Britto e Júlio Diniz.]. http://marcossiscar.blogspot.com.br/2012_10_01_archive.html.

STAIGER, Emil. Conceitos fundamentais da poética. Rio de Janeiro: Tempo Brasileiro, 1975.

STALLONI, Yves. Os gêneros Literários. Trad. Flávia Nascimento. $3^{a}$ ed. Rio de Janeiro, DIFEL, 2007.

VALÉRY, Paul. Poesia e Pensamento Abstrato. In: Variedades. São Paulo: Iluminuras, 1999. 